\title{
Evaluation of a Hydrothermal Anomaly Near Ennis, Montana
}

U.S. GEOLOGICAL SURVEY PROFESSIONAL PAPER 1044-K

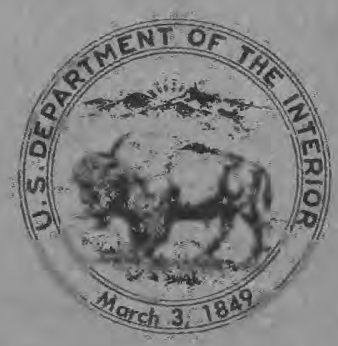




\section{AVAILABILITY OF BOOKS AND MAPS OF THE U.S. GEOLOGICAL SURVEY}

Instructions on ordering publications of the U.S. Geological Survey, along with prices of the last offerings, are given in the current-year issues of the monthly catalog "New Publications of the U.S. Geological Survey." Prices of available U.S. Geological Survey publications released prior to the current year are listed in the most recent annual "Price and Availability List." Publications that are listed in various U.S. Geological Survey catalogs (see back inside cover) but not listed in the most recent annual "Price and Availability List" are no longer available.

Prices of reports released to the open files are given in the listing "U.S. Geological Survey Open-File Reports," updated monthly, which is for sale in microfiche from the U.S. Geological Survey, Books and Open-File Reports Section, Federal Center, Box 25425 , Denver, CO 80225. Reports released through the NTIS may be obtained by writing to the National Technical Information Service, U.S. Department of Commerce, Springfield, VA 22161; please include NTIS report number with inquiry.

Order U.S. Geological Survey publications by mail or over the counter from the offices given below.

\section{BY MAIL}

\section{Books}

Professional Papers, Bulletins, Water-Supply Papers, Techniques of Water-Resources Investigations, Circulars, publications of general interest (such as leaflets, pamphlets, booklets), single copies of Earthquakes \& Volcanoes, Preliminary Determination of Epicenters, and some miscellaneous reports, including some of the foregoing series that have gone out of print at the Superintendent of Documents, are obtainable by mail from

\section{U.S. Geological Survey, Books and Open-File Reports Federal Center, Box 25425 \\ Denver, CO 80225}

Subscriptions to periodicals (Earthquakes \& Volcanoes and Preliminary Determination of Epicenters) can be obtained ONLY from the

\section{Superintendent of Documents Government Printing Ofrice Washington, D.C. 20402} ments.)

(Check or money order must be payable to Superintendent of Docu-

\section{Maps}

For maps, address mail orders to

$$
\begin{gathered}
\text { U.S. Geological Survey, Map Distribution } \\
\text { Federal Center, Box } 25286 \\
\text { Denver, CO } 80225
\end{gathered}
$$

Residents of Alaska may order maps from

$$
\begin{gathered}
\text { Alaska Distribution Section, U.S. Geological Survey, } \\
\text { New Federal Building - Box } 12 \\
101 \text { Twelfth Ave., Fairbanks, AK } 99701
\end{gathered}
$$

\section{OVER THE COUNTER}

\section{Books}

Books of the U.S. Geological Survey are available over the counter at the following Geological Survey Public Inquiries Offices, all of which are authorized agents of the Superintendent of Documents:

- WASHINGTON, D.C.--Main Interior Bldg., 2600 corridor, 18 th and C Sts., NW.

- DENVER, Colorado--Federal Bldg., Rm. 169, 1961 Stout St.

- LOS ANGELES, California--Federal Pldg., Rm. 7638, 300 N. Los Angeles St.

- MENLO PARK, California--Bldg. 3 (Stop 533), Rm. 3128 , 345 Middlefield Rd.

- RESTON, Virginia--503 National Center, Rm. 1C402, 12201 Sunrise Valley Dr.

- SALT LAKE CITY, Utah--Federal Bldg., Rm. 8105, 125 South State St.

- SAN FRANCISCO, California--Customhouse, Rm. 504, 555 Battery St.

- SPOKANE, Washington--U.S. Courthouse, Rm. 678, West 920 Riverside Ave.

- ANCHORAGE, Alaska--Rm. 101, 4230 University Dr.

- ANCHORAGE, Alaska--Federal Bldg, Rm. E-146, 701 C St.

\section{Maps}

Maps may be purchased over the counter at the U.S. Geological Survey offices where books are sold (all addresses in above list) and at the following Geological Survey offices:

- ROLLA, Missouri-1400 Independence Rd.

- DENVER, Colorado--Map Distribution, Bldg. 810, Federal Center

- FAIRBANKS, Alaska--New Federal Bldg., 101 Twelfth Ave. 


\section{Evaluation of a Hydrothermal Anomaly Near Ennis, Montana}

By ROBERT B. LEONARD and WAYNE A. WOOD

GE OH Y D R O O G Y OF GE T T ER M A L S S T E M S

U.S. GEOLOGICAL SURVEY PROFESSIONAL PAPER $1044-\mathrm{K}$

Prepared in cooperation with the

MONTANA BUREAU OF MINES AND GEOLOGY

Determination of regional and local geologic

framework, geohydrology, and geochemistry of

a hot spring and associated hydrothermal system

in a valley-fill environment

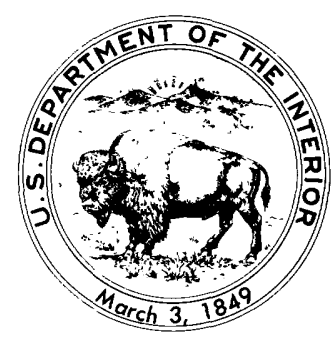

UNITED STATES GOVERNMENT PRINTING OFFICE, WASHINGTON : 1988 
DEPARTMENT OF THE INTERIOR

DONALD PAUL HODEL, Secretary

\section{U.S. GEOLOGICAL SURVEY}

Dallas L. Peck, Director

Library of Congress Cataloging-in-Publication Data

Leonard, Robert B.

Evaluation of a hydrothermal anomaly near Ennis, Montana.

(Geohydrology of geothermal systems) (Geological Survey professional paper ; 1044-K)

"Prepared in cooperation with the Montana Bureau of Mines and Geology."

Bibliography: p.

Supt. of Docs. no.: I 19.16:1044-K

1. Hot springs-Montana-Ennis. professional paper ; 1044-K.

GB1198.3.M9L46 1988

I. Wood, Wayne A. II. Title. III. Series.

IV. Series: Geological Survey

$551.2^{\prime} 3$ '09786663

86-607935

For sale by the Books and Open-File Reports Section,

U.S. Geological Survey

Federal Center, Box 25425,

Denver, CO 80225 


\section{CONTENTS}

Abstract .

Introduction

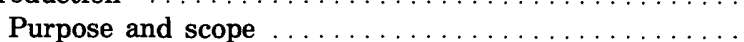

Acknowledgments $\ldots \ldots \ldots \ldots \ldots \ldots \ldots \ldots \ldots \ldots$

Hydrogeologic setting $\ldots \ldots \ldots \ldots \ldots \ldots \ldots \ldots$

Surface geophysical investigations $\ldots \ldots \ldots \ldots \ldots \ldots \ldots$

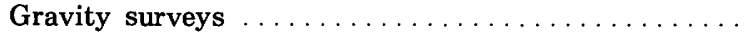

Seismic-refraction profiles $\ldots \ldots \ldots \ldots \ldots \ldots \ldots$

Electrical techniques . . . . . . . . . . . . . .

Audio-magnetotelluric soundings $\ldots \ldots \ldots \ldots \ldots$

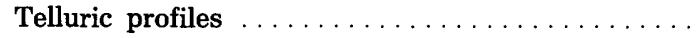

Direct-current resistivity soundings $\ldots \ldots \ldots \ldots \ldots$

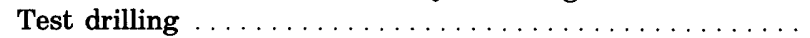

Borehole geophysical logging $\ldots \ldots \ldots \ldots \ldots \ldots \ldots$

Temperature gradients and heat flow $\ldots \ldots \ldots \ldots \ldots \ldots$

Geohydrology

Shallow discharge of thermal water

Page
$\mathrm{K} 1$
$\vdots$
2
3
3
6
6
6
8
8
8
9
9
11
12
20
21

Geohydrology-Continued

Water levels and direction of flow in valley fill ..... K21

Temperature corrections $\ldots \ldots \ldots \ldots \ldots \ldots \ldots \ldots, 23$

Datum corrections ................... 25

Geochemistry ....................... $\quad 28$

Sample collection and processing $\ldots \ldots \ldots \ldots \ldots \ldots . \ldots \ldots$

Chemical characteristics of the water . . . . . . . . 28

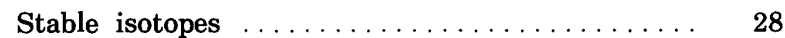

Gases and radioactivity ................ 28

Distribution of major ions . . . . . . . . . . $\quad 29$

Chemical quality in relation to use . . . . . . . 33

Geothermometry $\ldots \ldots \ldots \ldots \ldots \ldots \ldots \ldots \ldots \ldots \ldots$

Conceptual models of the hydrothermal system ....... 36

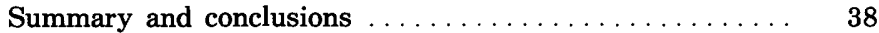

Selected references $\ldots \ldots \ldots \ldots \ldots \ldots \ldots \ldots \ldots \ldots \ldots, 40$

Tables .......................... 43

\section{ILLUSTRATIONS}

Figures 1-5. Maps showing:

1. Regional geologic setting of hot springs in southwestern Montana $\ldots \ldots \ldots \ldots \ldots \ldots \ldots \ldots$

2. Generalized geology near Ennis Hot Spring and location of selected wells and one test hole in adjacent areas

3. Bouguer gravity, faults, and location of wells, test holes, shotholes, and springs . . . . . . . . . . . .

4. Apparent resistivity determined by audio-magnetotelluric soundings at Ennis Hot Spring-and adjacent areas

5. Apparent resistivity of valley fill near Ennis Hot Spring $\ldots \ldots \ldots \ldots \ldots \ldots \ldots \ldots \ldots \ldots \ldots \ldots$

6. Geophysical logs, lithologic summary, and temperature gradients for test hole TX-9 $\ldots \ldots \ldots \ldots \ldots \ldots$

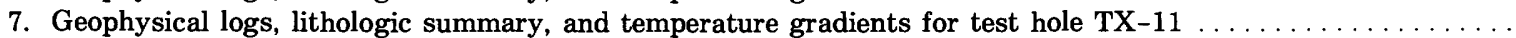

8. Section $A-A^{\prime}$ showing configuration of bedrock surface, measured and estimated temperatures, and water levels between shotholes SH-3 and SH-5

9. Section $B-B^{\prime}$ showing configuration of bedrock surface, measured and estimated temperatures, and water levels

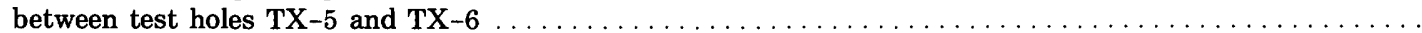

10. Temperature-depth profiles for test holes and shotholes in Ennis Hot Spring area $\ldots \ldots \ldots \ldots \ldots \ldots \ldots$

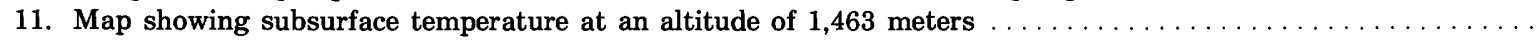

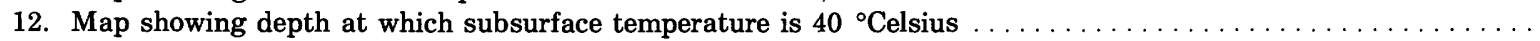

13. Graph illustrating thermal model of a hot spring in a basin-and-range setting $\ldots \ldots \ldots \ldots \ldots \ldots$ 14-17. Maps showing:

14. Temperature in shallow test holes near Ennis Hot Spring, October 10, $1978 \ldots \ldots \ldots \ldots \ldots$

15. Altitude of potentiometric surface in shallow test holes near Ennis Hot Spring, October 10, $1978 \ldots \ldots$

16. Uncorrected altitude of water levels in valley-fill deposits, $1978-79 \ldots \ldots \ldots \ldots \ldots \ldots \ldots \ldots$

17. Cold-water equivalent hydraulic heads in valley fill adjusted to a datum of 1,400 meters above sea level, 1978-79

18. Trilinear diagram showing percentage composition of water samples from wells, test holes, and springs .....

19. Map showing distribution of water-type fields in samples from wells, test holes, shotholes, and Ennis Hot Spring

20. Diagram illustrating conceptual model of the hydrothermal system that includes Ennis Hot Spring ......... 


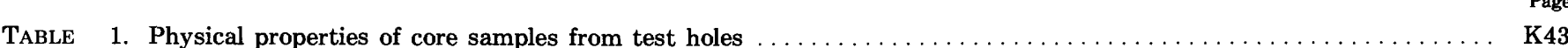

2. Water levels, subsurface temperatures, and geothermal gradients from wells, test holes, and shotholes ....... 44

3. Selected chemical analyses and minimum equilibrium temperatures of water from wells, test holes, shotholes, and springs 52

\section{CONVERSION FACTORS}

For readers who prefer to use units other than those used in this report, conversion factors are listed below.

\begin{tabular}{|c|c|c|c|c|c|}
\hline Multiply & By & To obtain & Multiply & By & To obtain \\
\hline Length & & & Gradient & & \\
\hline centimeter $(\mathrm{cm})$ & 0.3937 & inch (in.) & meter per meter $(\mathrm{m} / \mathrm{m})$ & 3.281 & foot per foot \\
\hline kilometer $(\mathbf{k m})$ & 0.6214 & mile & & & \\
\hline meter $(\mathrm{m})$ & 3.281 & foot & Temperature gradient & & \\
\hline millimeter $(\mathrm{mm})$ & 0.03937 & inch & degree Celsius per & 0.05486 & degree Fahrenheit \\
\hline Area & & & $\begin{array}{l}\text { kilometer } \\
\left({ }^{\circ} \mathrm{C} / \mathrm{km}\right)\end{array}$ & & per 100 feet \\
\hline hectare (ha) & 2.471 & acre & Heat flow & & \\
\hline Flow rate & & & Meat jow & & \\
\hline liter per second $(\mathrm{L} / \mathrm{s})$ & 15.85 & gallon per minute & $\begin{array}{l}\text { milliwatt per meter } \\
\text { squared } \\
\left(\mathrm{mW} / \mathrm{m}^{2}\right)\end{array}$ & $2.390 \times 10^{-2}$ & $\begin{array}{l}\text { heat-flow unit } \\
\text { (HFU) }\end{array}$ \\
\hline Velocity & & & & & \\
\hline meter per second $(\mathrm{m} / \mathrm{s})$ & 3281 & font nor gocond & Thermal conductivity & & \\
\hline Gravity & & 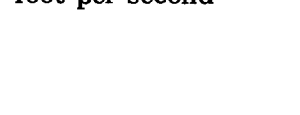 & $\begin{array}{l}\text { watt per meter per } \\
\text { degree Celsius } \\
(\mathrm{W} / \mathrm{m}) /{ }^{\circ} \mathrm{C}\end{array}$ & 2.390 & $\begin{array}{l}\text { millicalorie per } \\
\text { centimeter second } \\
\text { degree Celsius (HCU) }\end{array}$ \\
\hline milligal $\left(\mathrm{cm} / \mathrm{s}^{2} \times 10^{-3}\right)$ & $3.281 \times 10^{-5}$ & $\begin{array}{l}\text { foot per second per } \\
\text { second }\left(\mathrm{ft} / \mathrm{s}^{2}\right)\end{array}$ & Density & & \\
\hline Transmissivity & & & $\begin{array}{l}\text { kilogram per cubic } \\
\text { meter }\left(\mathrm{kg} / \mathrm{m}^{3}\right)\end{array}$ & 0.001 & gram per cubic centimeter \\
\hline $\begin{array}{l}\text { meter squared per day } \\
\left(\mathrm{m}^{2} / \mathrm{d}\right)\end{array}$ & 10.76 & foot squared per day & $\begin{array}{l}\text { gram per cubic } \\
\text { centimeter }\left(\mathrm{g} / \mathrm{cm}^{3}\right)\end{array}$ & 0.001 & kilogram per cubic meter \\
\hline
\end{tabular}

Temperature can be converted from degrees Celsius $\left({ }^{\circ} \mathrm{C}\right)$ to degrees Fahrenheit $\left({ }^{\circ} \mathrm{F}\right)$ using the following equation:

$$
{ }^{\circ} \mathrm{F}=9 / 5\left({ }^{\circ} \mathrm{C}\right)+32
$$




\title{
EVALUATION OF A HYDROTHERMAL ANOMALY NEAR ENNIS, MONTANA
}

\author{
By ROBERT B. LEONARD and WAYNe A. WOOD
}

\section{ABSTRACT}

Ennis Hot Spring was evaluated to determine the regional and local geologic framework, geohydrology, and geochemistry of the spring and the associated hydrothermal system. The exploratory methods used in the evaluation are described in detail. The spring was selected for study because it appeared to typify hot springs in the valley-fill environment in Montana and to closely resemble springs in known geothermal systems in the Basin and Range physiographic province in States to the south and west.

Ennis Hot Spring issues from valley fill in the Madison River valley in southwestern Montana. The measured surface temperature of 83 ${ }^{\circ}$ Celsius is the highest for natural springs in the State. Valley fill of late Cenozoic age overlies fractured gneiss and schist of Proterozoic age; the gneiss and schist are exposed about 2.5 kilometers west of the spring. The valley fill is in fault contact with similar crystalline rock along the active Madison fault zone about 10 kilometers to the east. Associated igneous rock is probably too old to be a source of residual magmatic heat for the spring.

Audio-magnetotelluric soundings indicate anomalously small resistivity values, probably caused by thermal water or rock alteration in an area of about 600 hectares, including the hot spring. A linear extension of the resistivity anomaly for 6 kilometers north of the spring probably represents leakage of thermal water along a series of faults or a fracture zone in the bedrock. The measured spring discharge of 1.2 liters per second is only a small part of the total discharge from the hot-water system.

Results of gravity surveys and seismic-refraction profiles and additional electrical soundings indicate that the spring overlies the eastern edge of a buried block of fractured crystalline rock bounded on the east and northeast by fault scarps that intersect about $\mathbf{4 5 0}$ meters north of the spring. A test hole drilled about 20 meters southwest of the predicted intersection penetrated fractured gneiss beneath valley fill at a depth of about 160 meters. The static head of water at a temperature of about $94{ }^{\circ} \mathrm{Celsius}$ from perforations in the depth interval between 157 and 177 meters was 12.3 meters above the land surface.

Subsurface temperatures measured in grouted test holes to a maximum depth of about 267 meters within 3 kilometers of the hot spring ranged from $6.2^{\circ} \mathrm{Celsius}$ near the water table in valley fill to 94.1 ${ }^{\circ}$ Celsius in fractured crystalline rock at a depth of 185.3 meters. Temperature gradients ranged from $-35^{\circ} \mathrm{Celsius}$ per kilometer near the margin of a convective cell to about $300{ }^{\circ} \mathrm{Celsius}$ per kilometer where conductive heat flow was dominant. Conductive heat flow exceeded 105 milliwatts per meter squared in nearly all test holes west of the Madison River in which the temperature was less than 50 ${ }^{\circ} \mathrm{Celsius}$. A relatively large $\left(88^{\circ} \mathrm{C}\right.$ elsius per kilometer) gradient below a depth of 137 meters in valley fill east of the Madison River is attributed to the small thermal conductivity of saturated clay. Minimum estimated reservoir temperatures are $165^{\circ} \mathrm{Celsius,} \mathrm{determined} \mathrm{from}$ a quartz geothermometer, and $166^{\circ} \mathrm{Celsius,} \mathrm{determined} \mathrm{from} \mathrm{a} \mathrm{cation}$ geothermometer.

Hydraulic head in discrete aquifers in the valley fill normally increased with depth and proximity to the conduit. Corrections for decrease in the density of water with temperature significantly lowered hydraulic-head values calculated from measured water levels in the hottest holes.

Local ground water is characterized by dissolved solids, in concentrations less than $\mathbf{4 0 0}$ milligrams per liter, that consist predominantly of calcium and bicarbonate ions. Relatively undiluted thermal water from flowing sources near the conduit contains dissolved solids in concentrations exceeding 950 milligrams per liter; predominant ions are sodium and sulfate plus chloride. Concentrations of fluoride in the thermal water exceed drinking-water standards of the U.S. Environmental Protection Agency. A chloride concentration of 120 milligrams per liter indicates a dominantly hot-water convective system. Associated helium and hydrogen indicate a deep crystalline-rock source.

The combined geohydrologic, geophysical, and hydrochemical data describe a system in which water heated by deep ( 2 to 5 kilometers) circulation rapidly ascends a fault-controlled conduit in fractured crystalline rock, spreads laterally in intersecting valley-fill aquifers, and forms a northeast-trending plume along the shallow hydraulic gradient. Hydraulic connection between wells in the vicinity of the conduit was confirmed.

\section{INTRODUCTION}

Most of the 24 hot (more than $38^{\circ} \mathrm{C}$ ) springs in southwestern Montana issue from fractured crystalline rock marginal to Cenozoic block-fault valleys or from adjacent valley fill (fig. 1). The water appears to acquire heat from terrestrial heat flow during deep circulation along known or inferred block faults or fractures in the predominantly crystalline crust. Eleven of the springs issue from exposed fracture or shear zones in crystalline rock, commonly at the intersection of faults. (The term "fracture," as used in this report, describes joints, shears, or other stress-induced openings along which water can move through normally impermeable rock.) Eight of the remaining springs issue from valley fill, which conceals conduits in the underlying bedrock and may include extensive geothermal aquifers (Chadwick and Leonard, 1979). The lack of reliable subsurface data at nearly all these springs constitutes a major obstacle to appraisal and development of the geothermal resource.

Ennis Hot Spring issues from valley fill in the Madison River valley about $2 \mathrm{~km}$ north of the community of Ennis in southwestern Montana. The surface temperature of $83^{\circ} \mathrm{C}$ is the hottest for natural springs in Montana. On the basis of preliminary data, it was 


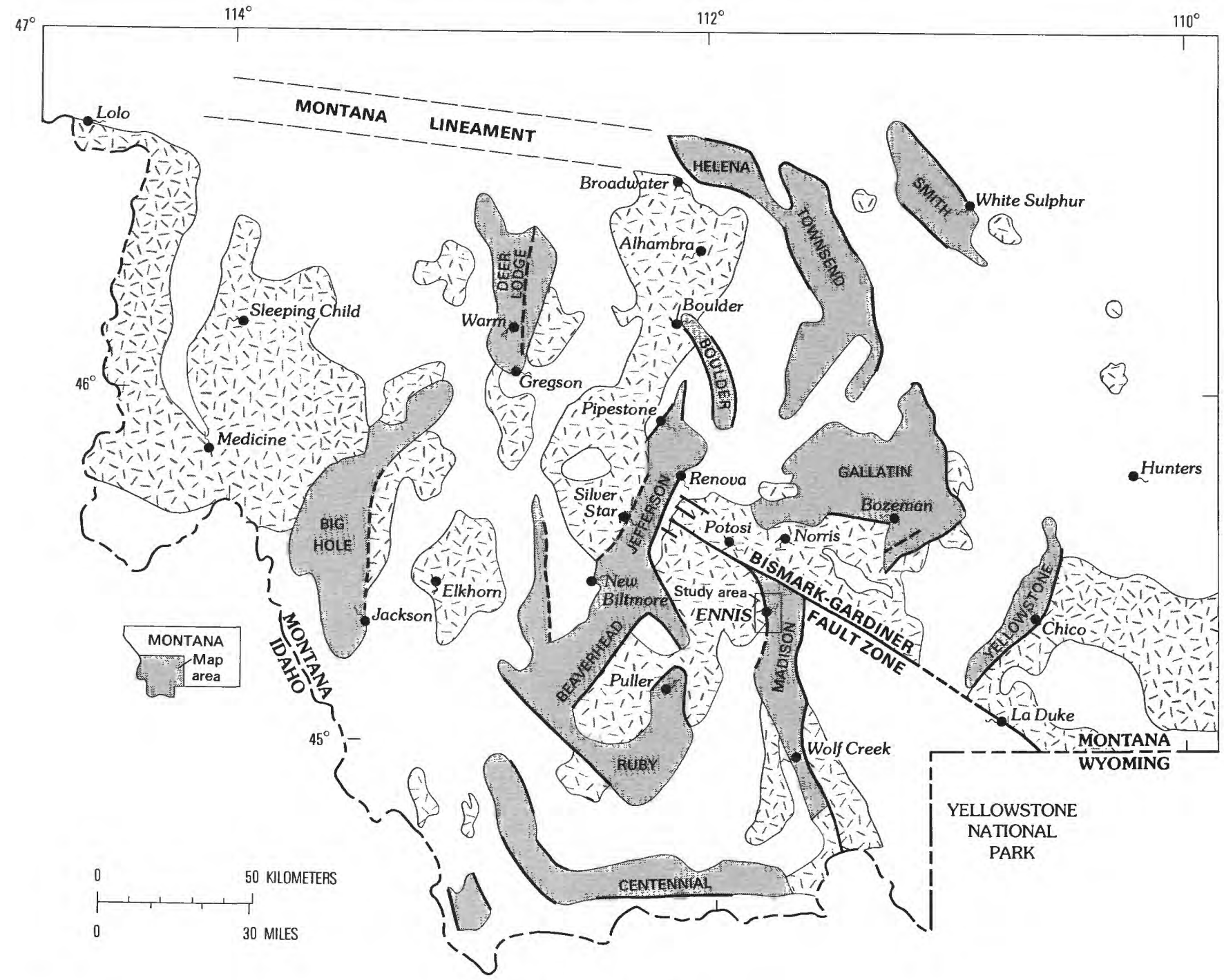

CENOZOIC SEDIMENTARY ROCKS IN PRINCIPAL BLOCK-FAULT VALLEYS-Name is valley identification CENOZOIC TO PROTEROZOIC CRYSTALLINE ROCKS

EXPLANATION

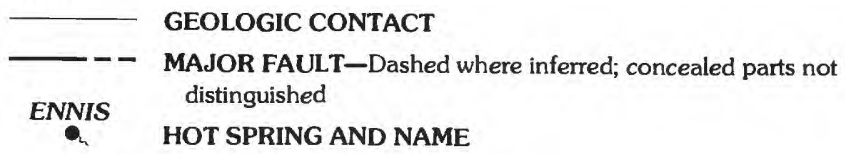

FigurE 1.-Regional geologic setting of hot springs in southwestern Montana (modified from Chadwick and Leonard, 1979).

classified as the only hot spring in the valley-fill environment in Montana associated with a hydrothermal convection system with reservoir temperatures equal to, or greater than, $90{ }^{\circ} \mathrm{C}$ (Brook and others, 1979, p. 74). Sammel (1979, p. 112) included Ennis Hot Spring in an area favorable for discovery and development of local sources of low-temperature (less than $90{ }^{\circ} \mathrm{C}$ ) geothermal water. Ennis Hot Spring was selected for detailed study because it appeared to typify hot springs in the valleyfill environment in Montana and to closely resemble springs in known geothermal systems in the Basin and
Range physiographic province in States to the south and west. Information describing the hydrothermal system associated with the spring, and the exploration methods used, can be helpful in evaluating and developing similar sites where subsurface data are unavailable.

\section{PURPOSE AND SCOPE}

The purpose of this report is to describe the regional and local geologic framework, the exploratory methods 
used in the investigation, the geohydrology, and the geochemistry of the hydrothermal system associated with Ennis Hot Spring. The report summarizes and evaluates the published and unpublished results of diverse studies conducted during $1975-80$ by the U.S. Geological Survey and cooperating agencies to determine the nature, source, extent, and configuration of the hydrothermal anomaly associated with the hot spring. The report is based mainly on data collected near the hot spring (Leonard and others, 1978; Leonard and Wood, 1980b) but includes a discussion of reasonable conceptual models of the hydrothermal system that are consistent with additional data.

The phases of the investigation included the following:

1. Topographic surveys to define the location and altitude of data points in the included maps and sections

2. Regional and local surface geologic studies to refine previous descriptions of the hydrogeologic framework

3. Surface geophysical studies using gravity, seismic, and electrical techniques to detect concealed geologic structure and thermal alteration in the subsurface

4. Test drilling; geophysical logging of test holes, seismic shotholes, and domestic wells; and examination and laboratory testing of drill cuttings and cores to describe the subsurface geologic and thermal regimes

5. Water-level, flow-rate, and pressure measurements to determine the distribution of pressure and the direction of ground-water flow

6. Collection and analysis of water and gas samples to describe the distribution of dissolved solids, gases, radioactivity, and stable isotopes. The analyses were used to estimate minimum equilibrium temperatures, to infer flow patterns, and to evaluate the suitability of water for use.

The objectives of the investigation were achieved to varying degrees. Data collected during the early phases of the investigation were used for the national assessments of geothermal resources (Muffler, 1979; Reed, 1983). Analyses of more diverse and detailed data collected subsequently and described herein do not significantly alter the estimates presented in those reports. A more specific objective, evaluation of subsurface conditions needed for guiding the siting and construction of large-diameter wells for pumping tests of the crystalline aquifer, was achieved. Partial results of those tests, performed as part of subsequent investigations by the Montana Bureau of Mines and Geology (Sonderegger and Zaluski, 1983; J.L. Sonderegger, Montana Bureau of Mines and Geology, oral commun., 1984), are included herein.

\section{ACKNOWLEDGMENTS}

Robert A. Chadwick of Montana State University directed preliminary surface geological and shallow geophysical studies (under U.S. Geological Survey grant numbers 14-08-0001-G-238 and 334, from 1975 through 1978) that led to the selection of the area for intensive study and the location of the initial test hole. A. Hayden Ferguson, also of Montana State University, provided equipment and personnel for installing shallow test wells in an area unsuitable for heavier equipment.

John L. Sonderegger of the Montana Bureau of Mines and Geology obtained funding for drilling several test holes and the seismic shotholes and for supplementary surface geophysical studies under the State-coordinated geothermal program supported by the U.S. Department of Energy. This phase of the drilling program, as well as the determination of the physical properties of drill cores, was ably conducted by personnel of the Montana Department of Highways.

Charles J. Wideman of the Montana College of Mineral Science and Technology directed the seismicrefraction surveys and part of the detailed gravity studies in the area again under the auspices of the State geothermal program. His assistance in the interpretation of the results of these and related geophysical studies in the area by the U.S. Geological Survey was invaluable. Recognition of efforts would be incomplete without mention of many students from Montana State University and Montana College of Mineral Science and Technology who participated in various phases of the investigation.

David D. Blackwell, Southern Methodist University, determined the thermal conductivity of the cores. Larry L. Lloyd, Montana Department of Health and Environmental Sciences, provided analyses for gross alpha and beta activities of the thermal waters.

Because much of the work was conducted on private land, the cooperation of many landowners is gratefully acknowledged. Special thanks are due to William G. Thexton, Robert Goggins, Daniel Leadbetter, George L. Boehm, and Mary I. Jeffers, among others, who provided access and cheerfully offered assistance and information despite obvious inconvenience to them.

This report was prepared in cooperation with the Montana Bureau of Mines and Geology.

\section{HYDROGEOLOGIC SETTING}

Ennis Hot Spring issues from a gravel layer within clay at the base of a gravel-capped terrace on the western edge of the flood plain of the Madison River (fig. 2). The linear edge of the terrace is interrupted by 


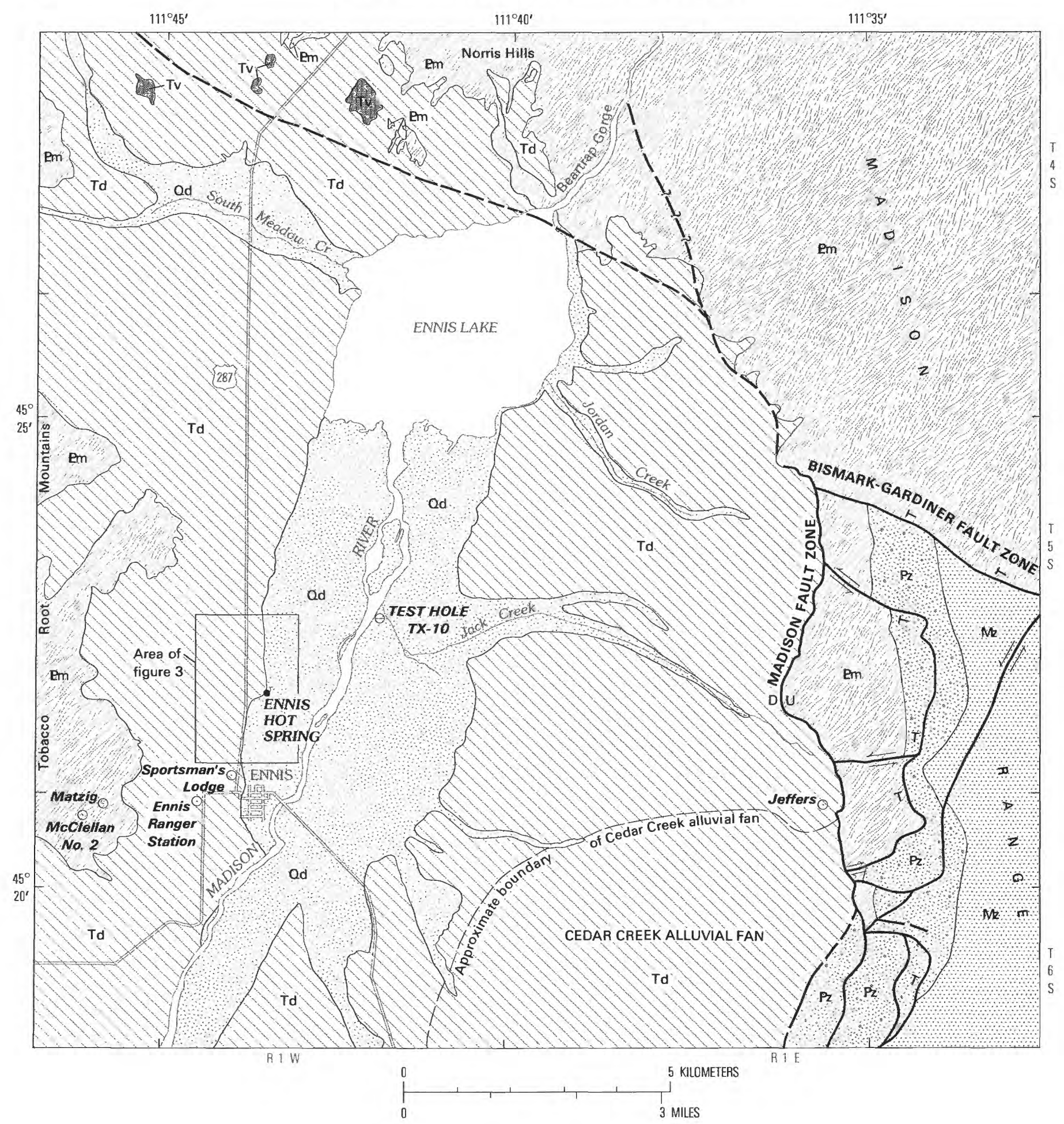

Figure 2 (above and facing page).-Generalized geology near Ennis Hot Spring and location of selected wells and one test hole in adjacent areas. Base modified from Swanson (1950) by aerial photography, 1972. Geology modified from Swanson (1950). 


\section{EXPLANATION}

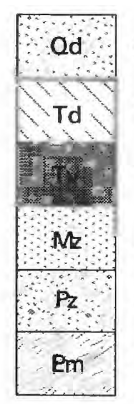

QUATERNARY DEPOSITS

TERTIARY VALLEY-FILL DEPOSITS

TERTIARY VOLCANIC ROCKS

MESOZOIC SEDIMENTARY ROCKS

PALEOZOIC SEDIMENTARY ROCKS

PROTEROZOIC METAMORPHIC ROCKS

GEOLOGIC CONTACT

- ? - FAULT -Dashed where approximately located; queried where doubtful U D STEEP-ANGLE FAULT $-U$, upthrown side; D, downthrown side

$=$ FAULT-Arrows indicate direction of relative movement

$\vdash$ THRUST FAULT $-T$, hanging wall

Jeffers

$\odot$ DOMESTIC WELL AND NAME OF OWNER

an easterly bulge near the hot spring, which probably results from resistant coarse sediment locally cemented with travertine and silica deposited from thermal water.

Two older and higher terraces in the valley fill conceal the bedrock between the hot spring and outcrops of feldspathic and hornblende gneiss and biotite schist of Proterozoic age exposed at the base of the Tobacco Root Mountains about $2.5 \mathrm{~km}$ to the west (fig. 2). Unless interrupted by a concealed range-front fault, the easterly sloping erosional surface of high local relief on the crystalline rock would extend under the hot spring.

Linear segments of the contact between the gneiss and the valley fill west of the spring resemble recent faults of unknown displacement, but they probably are actually depositional boundaries along erosional scarps that developed along older faults or fracture zones. East-trending mafic dikes and randomly oriented quartz veins and pegmatitic zones transect the outcrops of the crystalline rock (Vitaliano and Cordua, 1979). Minor transverse faults and vertical fracture and shear zones that interrupt the northeast-trending foliation of the gneiss might provide conduits for deep circulation of meteoric water. Surface geologic evidence supporting their continuation in the valley fill is tenuous.

Subtle changes in drainage and vegetation patterns observed in aerial photographs may indicate recent displacement of the valley sediments along a poorly defined lineament that passes from the vicinity of the spring to a major fracture zone of the gneiss about $3 \mathrm{~km}$ to the northwest. The north-trending linear edge of the bench above the hot spring may overlie the trace of a fault or buried scarp in the bedrock parallel to the
Madison fault zone to the east. Minor faults resulting from differential compaction of the valley fill draped over erosional scarps, as well as recent bedrock displacement, could be the conduits for the ascending thermal water.

About $10 \mathrm{~km}$ north of the spring, crystalline rock underlying the Norris Hills effectively closes the valley downstream from Ennis Lake (fig. 2). The Madison River, braided east of the spring, has incised the narrow Beartrap Gorge to flow through the fractured rock of the Norris Hills.

East of Ennis Lake, steeply dipping quartzite conglomerate is in fault contact with the underlying Proterozoic metamorphic rock and is overlain by calcareous sedimentary breccia, calcareous and tuffaceous sandstone, siltstone, and clay. The northwest-trending normal fault is apparently part of a continuation of the extensive Bismark-Gardiner fault zone (figs. 1 and 2) near its intersection with the seismically active Madison fault zone, which is mapped as a single range-front fault. Using fossils from presumably correlative freshwater limestone exposed west of the Madison River south of Ennis, Swanson (1955, p. 7) and Montagne (1960, p. 169) dated the sedimentary beds as late Cenozoic age, perhaps Pleistocene. Montagne, however, also noted their resemblance to Miocene rocks exposed in the Madison valley about $30 \mathrm{~km}$ to the north.

Extrusive and partly intrusive rhyolite occurs within the valley fill north of the hot spring, and basalt intrusions are exposed in Trail Creek, about $7 \mathrm{~km}$ south of Ennis. Radiometric dating of surface-rock samples from presumably similar stratigraphic positions in surrounding areas (Chadwick, 1978a) indicates that igneous rocks in the study area are probably too old (more than 1 million yr; Smith and Shaw, 1975) to be the sources of residual magmatic heat for the hot spring. In the absence of a younger volcanic system, deep circulation of water is required to obtain the temperature measured at the spring.

About $10 \mathrm{~km}$ east of the spring, gneiss and sedimentary rock of Proterozoic to Mesozoic age are exposed along the regional Madison fault zone at the base of the Madison Range along the eastern edge of the valley. Swanson (1950) included the gneiss in a plate, overthrust to the east, bounded and intersected by cross faults. The western extensions (roots) of these thrust faults probably underlie the study area. During late Cenozoic (Pleistocene) time, the western part of the plate dropped as much as $1,830 \mathrm{~m}$ along the rejuvenated Madison fault zone (Pardee, 1950), forming a half graben filled with volcanic debris and sediment eroded from the surrounding highlands. Bounding faults along the west side of the valley, if present, are presumed to have relatively small displacement. 
Displacement and eastward tilting of Pleistocene to Holocene colluvium and alluvium, with the formation of triangular facets and a discontinuous scarp that extends $64 \mathrm{~km}$ along the west flank of the Madison Range in and south of the study area, indicate recent movement on the Madison fault (Pardee, 1950, p. 369; Witkind, 1975). The study area is within an active earthquake zone (Smith and Sbar, 1974, fig. 1); residents reported mudslides and disruption of the flow of springs and wells associated with earthquake activity as recently as 1959. The seismic activity tends to maintain open conduits for the deep circulation of meteoric and geothermal waters through new or existing fracture zones associated with the thrust and normal faulting. Perennial streamflow in the Madison River valley and annual precipitation exceeding $1,000 \mathrm{~mm}$ in the surrounding highlands (Johnson and Omang, 1976) provide adequate potential recharge for the hydrothermal system.

The combined local and regional surface geologic data indicated that the hot spring might be near the intersection of a north-northeast-trending fault and a transverse northwest-trending fault which penetrate an undetermined thickness of locally variable, stratified valley fill. Therefore, surface geophysical surveys were conducted to detect the location and extent of concealed scarps, faults, fracture zones, and associated zones of thermal alteration in the subsurface.

\section{SURFACE GEOPHYSICAL INVESTIGATIONS}

\section{GRAVITY SURVEYS}

Regional gravity data (Burfeind, 1967) indicate that the bedrock surface, exposed west of Ennis Hot Spring, slopes gently to the east from a depth of about $0.23 \mathrm{~km}$ under the hot spring to a depth of about $1.2 \mathrm{~km}$ near the Madison fault. Thus, the data confirm the geologic portrayal of the paleovalley as a half graben.

The spring evidently does not overlie a range-front fault of major displacement along the west edge of the valley similar to the Madison fault along the east edge of the valley. Instead, the easterly slope of the bedrock surface may be the cumulative effect of a series of northtrending step faults of relatively small displacement downthrown to the east. Localized geophysical studies were conducted to test the hypothesis of Chadwick and Leonard $(1979$, p. 15$)$ that the hot spring overlies one of the step faults, perhaps near its intersection with a northwest-trending transverse fault.

Altitudes of stations within the study area were computed from traverses to known bench marks using transit, level, and computerized surveying instruments. Although surveys for various phases of the investigations were made using different instruments, operators, and reference points, the accuracy of the combined surveys is estimated to be $1 \mathrm{~m}$ in the horizontal direction and $0.3 \mathrm{~m}$ in the vertical direction, referred to a common reference point. Outside the study area, altitudes were estimated from the U.S. Geological Survey 15-minute topographic map of Ennis, Mont., which has a scale of $1: 62,500$ and a contour interval of $12.2 \mathrm{~m}$. There, estimates probably are accurate within $10 \mathrm{~m}$ in the vertical direction and $100 \mathrm{~m}$ in the horizontal direction.

A Bouguer anomaly map (fig. 3) is based on detailed gravity surveys by the Montana College of Mineral Science and Technology (C.J. Wideman, written commun., 1979) and the U.S. Geological Survey (Senterfit, 1980; Bankey and others, 1980). The map shows an abrupt change in the direction of the gravity lines from a regional north-northeast trend (Burfeind, 1967) to a northwest trend about $450 \mathrm{~m}$ north of the spring. A block of gneiss and schist (density $2.6 \mathrm{~g} / \mathrm{cm}^{3}$, test hole TX-11, table 1), which is buried in valley fill (density $2.1 \mathrm{~g} / \mathrm{cm}^{3}$ ) and is bounded on the east and northeast by steep faults or scarps that intersect north of the spring, could cause the gravity anomaly.

\section{SEISMIC-REFRACTION PROFILES}

Two intermediate-depth seismic-refraction profiles by personnel from the Montana College of Mineral Science and Technology (Mark McCrae, written commun., 1979; C.J. Wideman, written commun., 1980) indicated a marked contrast between the velocity in the bedrock $(4,600-5,200 \mathrm{~m} / \mathrm{s})$ and that in the overlying valley fill. A surficial layer of poorly consolidated cobbles, gravel, and sand as much as $60 \mathrm{~m}$ thick exhibits a velocity of $1,160-1,310 \mathrm{~m} / \mathrm{s}$; its base is fairly well defined. Strata in the underlying valley fill, with velocities ranging from about 1,900 to $3,000 \mathrm{~m} / \mathrm{s}$, appear nearly horizontal but discontinuous.

Although subject to varied interpretations, the results generally confirm the presence of a major northtrending scarp along a fault in the bedrock, downthrown about $70 \mathrm{~m}$ to the east, near the spring. The fault intersects a northwest-trending transverse fault, downthrown to the northeast, about $450 \mathrm{~m}$ north of the spring. A test hole (TX-11) penetrated the crystalline bedrock near the predicted depth of about $160 \mathrm{~m}$ near the intersection. A second set of faults nearly parallel to these faults appears to intersect southwest of test hole TX-9 (fig. 3 ). 


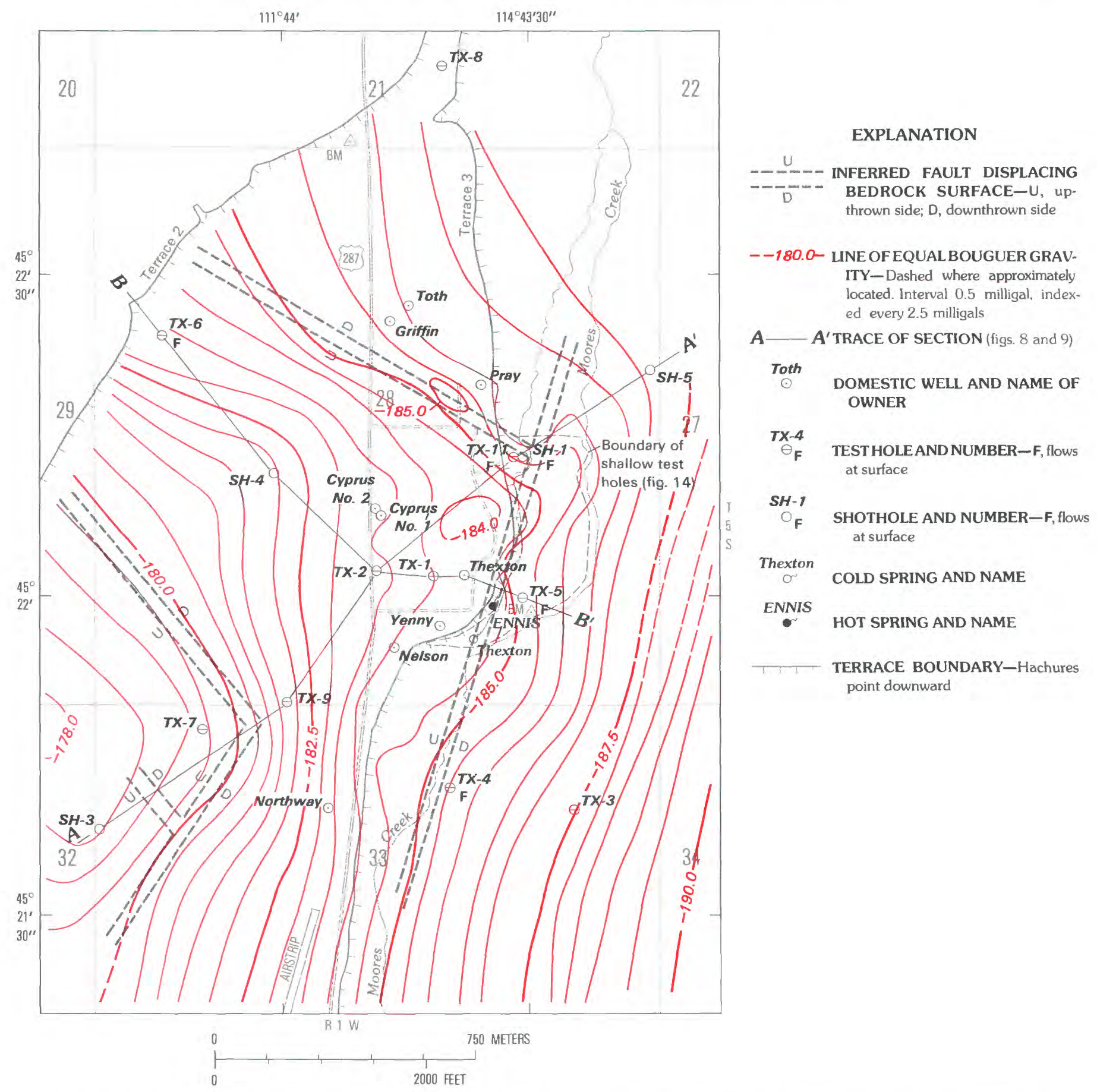

Figure 3.-Bouguer gravity, faults (inferred from surface geophysical investigations), and location of wells, test holes, shotholes, and springs. Map compiled from gravity data from Senterfit (1980), Bankey and others (1980), and C.J. Wideman (Montana College of Mineral Science and Technology, written commun., 1979) and from seismic-refraction data of C.J. Wideman (written commun., 1980), and Mark McCrae (Montana College of Mineral Science and Technolngy, written commun., 1979).

Several shallow seismic profiles were made near the spring by personnel from Montana State University using a signal-enhancement seismograph. R.A. Chadwick (written commun., 1977) reported a thickness of
$10 \mathrm{~m}$ of cobble, gravel, and silt, having a velocity of $600 \mathrm{~m} / \mathrm{s}$, beneath the surface of the terrace west of the spring. The underlying unit, which has a seismic velocity of $2,400 \mathrm{~m} / \mathrm{s}$, slopes gently eastward to a line 
trending N. $10^{\circ}$ E. about $100 \mathrm{~m}$ west of the spring. East of the line, which may represent the eroded edge of a pediment or a fault scarp, the surface slopes more steeply to the east. The velocity boundary corresponds to the contact between coarse sediment and the underlying saturated clay penetrated in test hole TX -1 . The shallow seismic profiles appear to confirm the considerable lateral variation in the physical properties of the valley fill observed in the outcrop and cuttings from subsequent test holes, but the profiles failed to define the bedrock surface.

\section{ELECTRICAL TECHNIQUES}

Electrical techniques are particularly useful in geothermal exploration to detect zones of decreased bulk resistivity associated with higher temperatures and greater water salinity and with hydrothermal alteration of the aquifers (Hoover and Long, 1976). For example, the resistivity of water from the Ennis Hot Spring at a temperature of $83{ }^{\circ} \mathrm{C}$ is about $3 \mathrm{ohm}-\mathrm{m}$, whereas the resistivity of water from the Thexton cold spring $100 \mathrm{~m}$ to the south at a temperature of $7.8{ }^{\circ} \mathrm{C}$ is $33 \mathrm{ohm}-\mathrm{m}$.

\section{AUDIO-MAGNETOTELLURIC SOUNDINGS}

Relatively small scalar resistivities measured during AMT (audio-magnetotelluric) soundings indicate the presence of thermal water or alteration of the valley fill by thermal water in an area of about 1.5 by $4 \mathrm{~km}(600$ ha) that is mainly southeast of the hot spring (Long and Senterfit, 1979). Anomalously small resistivity values, represented by the $27-\mathrm{Hz}$ (hertz) band, trend northward through the spring to Ennis Lake, about $6 \mathrm{~km}$ to the north (fig. $4 A$ ), where a second resistivity depression may define a zone of thermal water that does not flow to the surface. The elongate anomaly probably represents leakage of thermal water along an almost north-trending series of faults or a fracture zone. Deeper northwest-trending anomalies, shown as the $7.5-\mathrm{Hz}$ band (fig. $4 B$ ), probably represent intersecting transverse faults mainly affecting the bedrock.

\section{TELLURIC PROFILES}

One of two single E-field ratio telluric profiles indicated the probable presence of a major fault, downthrown to the east, in the vicinity of the hot spring. A broad 250-m zone of alteration and thermal water is indicated by small resistivity values east of the postulated
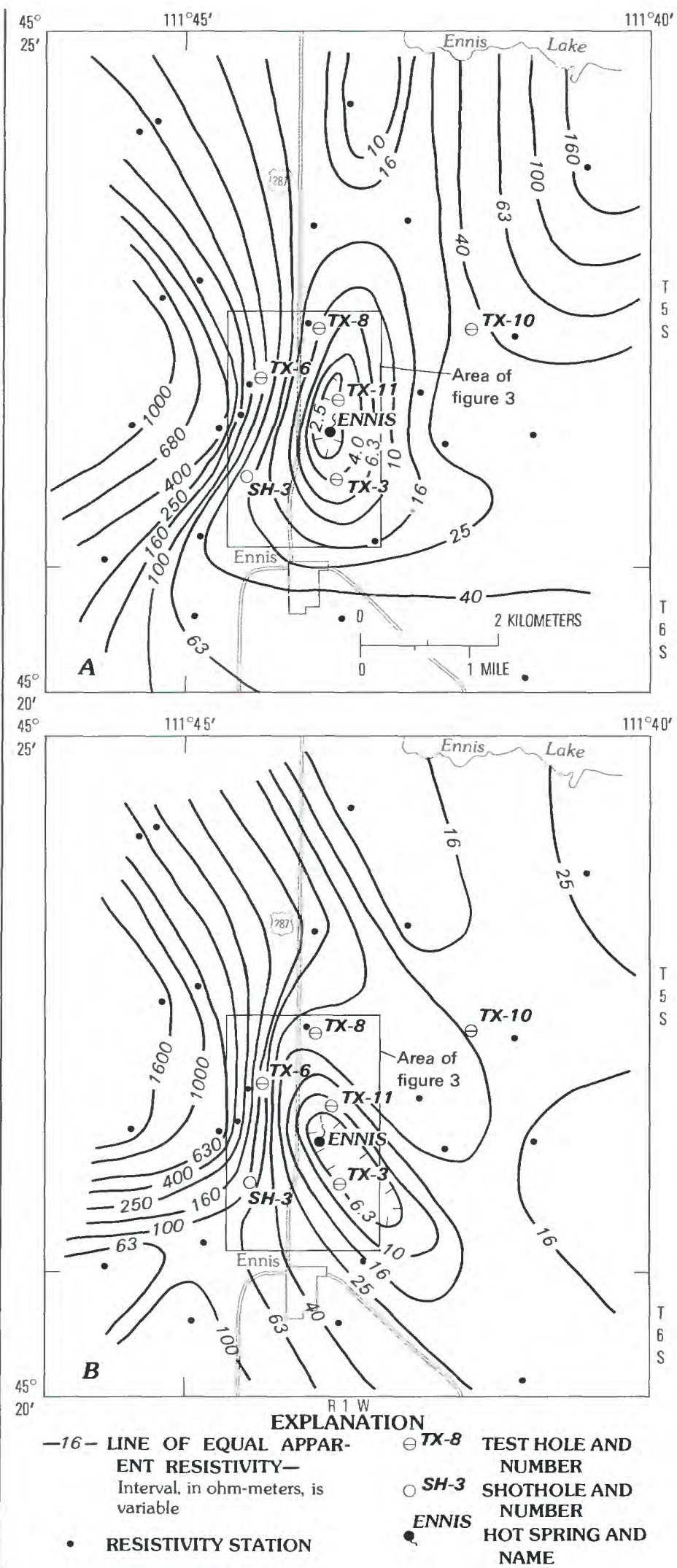
fault. Data from the second traverse are somewhat contradictory and suspect, providing further evidence for a complex subsurface structure and perhaps another fault or fracture zone trending about $\mathrm{N} .45^{\circ} \mathrm{W}$., downthrown to the west-southwest, southwest of the hot spring (Christopherson and others, 1979).

\section{DIRECT-CURRENT RESISTIVITY SOUNDINGS}

Shallow (depth $100 \mathrm{~m}$ ) direct-current resistivity soundings by Montana State University personnel using a Wenner configuration indicated small apparent resistivity values near the hot spring. Apparent resistivity values at a depth $20 \mathrm{~m}$ below the altitude of a bench mark near the base of the terrace describe a generally elliptical depression, trending northnortheast, nearly centered on the hot spring (fig. $5 A$ ). The depression corresponds with a zone of seepage of thermal water on the valley floor. At a depth of $100 \mathrm{~m}$ (fig. $5 B$ ), the smallest resistivity values are about $200 \mathrm{~m}$ northeast of the hot spring, perhaps as a result of upwelling of thermal water from this direction (R.A. Chadwick, written commun., 1977). The soundings failed to identify small resistivity values associated with hot $\left(89^{\circ} \mathrm{C}\right)$ water at a depth of $25 \mathrm{~m}$ in test hole TX-1 west of the hot spring. The location and configuration of the anomalies depicted in figure 5 indicate that the results might have been unduly affected by the differing electrical conductivity of the terrace's well-drained cobble layer and the soil in the area of seepage on the valley floor.

The combined data from surface geophysical investigations lead to the conclusion that the hot spring overlies an almost north-trending fracture zone associated with an erosional scarp or step fault downthrown to the east in the bedrock. The main bedrock conduit for the spring may be a fracture zone at the intersection with a northwest-trending transverse fault about $450 \mathrm{~m}$ north of the spring, but leakage of thermal water extends at least as far north as Ennis Lake.

\section{TEST DRILLING}

Eleven test holes (TX-1 to TX-9, and TX-11, fig. 3; $\mathrm{TX}-10$, northeast of the study area, fig. 2) and five shotholes (SH-1 to $\mathrm{SH}-5$, fig. 3) were drilled from October 1977 to November 1979. Measured final depths

Figure 4 (facing page).-Apparent resistivity determined by audio-magnetotelluric soundings at Ennis Hot Spring and adjacent areas. $A, 27$-hertz band, telluric line east-west. $B, 7.5$-hertz band, average of east-west and north-south scalar impedance. Maps interpreted by C.L. Long (U.S. Geological Survey, written commun., 1979) from data in Long and Senterfit (1979). of the test holes ranged from $15.2 \mathrm{~m}$ in TX-7 to $267 \mathrm{~m}$ in TX-10. The purpose of the drilling was to obtain data describing the structure, lithology, and physical properties of the valley fill and bedrock; the temperature and hydraulic gradients of the ground water; and the chemical composition of the ground water and associated gases. These data are needed to describe the extent of the geothermal anomaly associated with the hot spring.

The test holes were designed for completion as temperature-gradient holes and were unsuitable for hydraulic testing. Most were completed with $50.8-\mathrm{mm}$ (2-inch nominal) diameter steel casing. Some were completed with screened sand points; others were selectively gun perforated to permit water sampling and waterlevel measurements. The annulus between the casing and the wall of each successfully completed test hole was grouted with cement to prevent vertical circulation of water that would disrupt the natural temperature gradient. Temperature profiles measured in nearby domestic wells with uncemented 152-mm diameter steel casing were generally erratic.

Physical properties of core samples from selected test holes are listed in table 1 . Water levels, subsurface temperatures, and other pertinent data for test holes, wells, and shotholes are listed in table 2.

TX-1, the first test hole, was designed to fully penetrate the valley fill west of the spring. The site was selected mainly on the basis of shallow seismic profiles that indicated a fault in shallow bedrock between the spring and the drill site. A basal high-velocity layer at a depth of $40 \mathrm{~m}$ beneath the drill site was interpreted as the Proterozoic bedrock surface (R.A. Chadwick, Montana State University, written commun., 1977).

The regional gravity study by Burfeind (1967) indicated that the bedrock surface was about $230 \mathrm{~m}$ beneath the hot spring. With a typical temperature gradient of about $60^{\circ} \mathrm{C} / \mathrm{km}$ in valley fill in southwestern Montana (Blackwell and Chapman, 1977; Leonard and Wood, 1980a), the thermal water would circulate well below the bedrock surface to attain the maximum temperature of about $83{ }^{\circ} \mathrm{C}$ that was measured at the hot spring (Leonard and others, 1978, p. 30). Therefore, the projected depth of the test hole was more than $300 \mathrm{~m}$.

As a result of mechanical difficulties, drilling was terminated in valley fill at a depth of $103 \mathrm{~m}$. Penetration of the projected bedrock surface at a depth of $40 \mathrm{~m}$ without significant changes in drilling rate, drilling-mud temperature, or lithology indicated the limitations of the shallow seismic surveys. However, alteration of the valley fill and the occurrence of hot $\left(89^{\circ} \mathrm{C}\right)$ water at a depth of $25 \mathrm{~m}$ denoted proximity to a conduit. The electrical and natural-gamma logging equipment performed erratically at the high temperature. The annulus could be grouted with cement to a depth of only $30.5 \mathrm{~m}$, but 


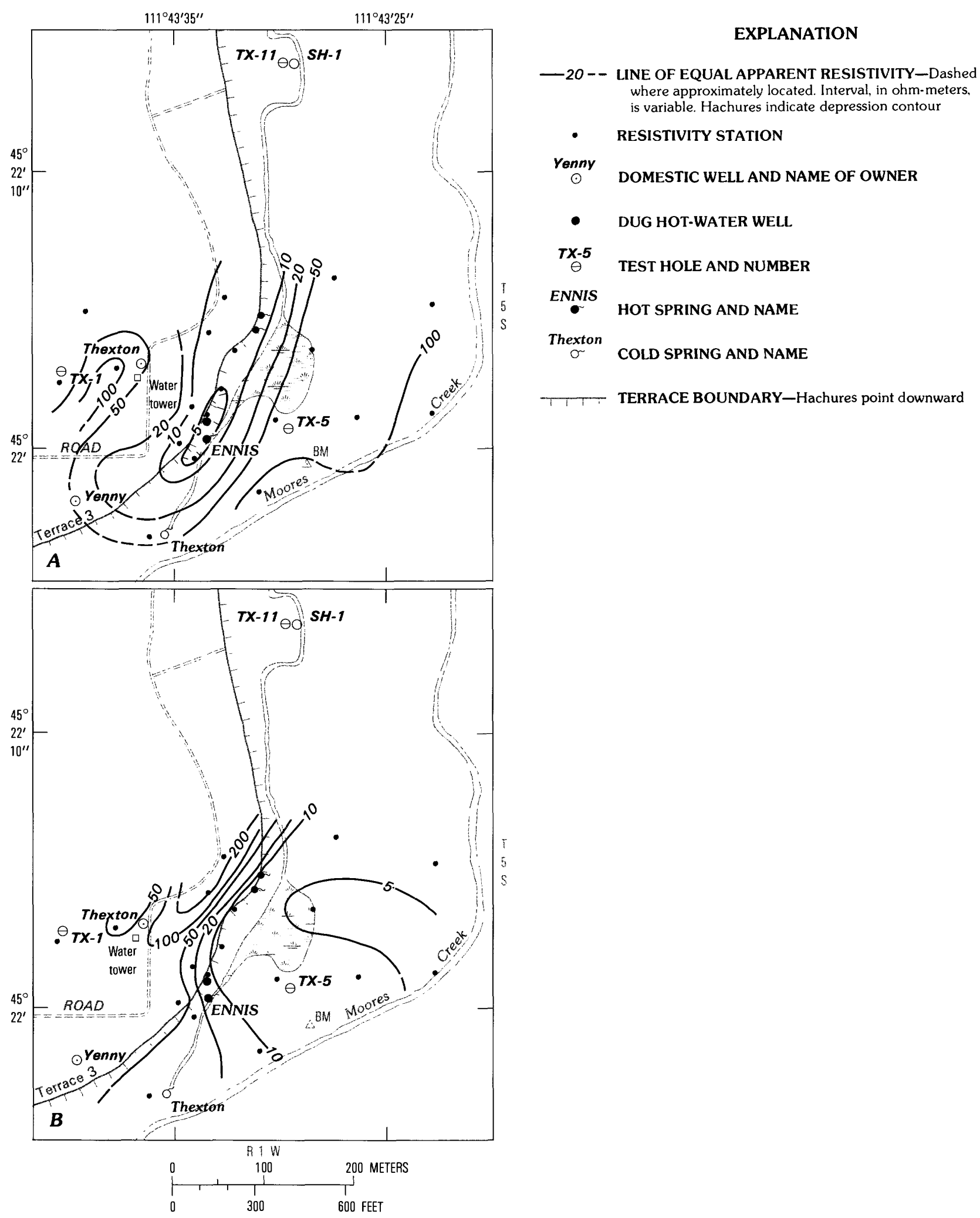

Figure 5.-Apparent resistivity of valley fill near Ennis Hot Spring. $A$, Depth of 20 ineters below base of terrace. $B$, Depth of 100 meters below base of terrace. 
the temperature logs are considered to be valid because vertical circulation in the lower part of the mud-filled hole probably was minimal.

Successful completion of test hole TX-1 in bedrock and reliable geophysical logging would have decreased the need for additional geophysical studies and drilling to achieve the objectives of the investigation. However, the results justified construction of additional test holes and defined the techniques and equipment needed for their completion. Each hole was sited for a specific purpose:

1. Test hole TX-2-To confirm the interpretation of the results of test hole $\mathrm{TX}-1$

2. Test holes TX-3 and TX-4-To define the southeastern limits of the anomaly in an area generally inaccessible to heavy drilling equipment

3. Test hole TX-5-To describe the subsurface conditions near and to the east of the hot spring and a suspected north-trending fault

4. Test hole TX-6-To define the northwestern limit of the anomaly and the possible effects of a northwest-trending fault

5. Test holes TX-7 and TX-9-To define the depth to bedrock and the southwest limits of the anomaly

6. Test hole TX-8-To define the extent of the anomaly at the most northeasterly site accessible to heavy drilling equipment west of the river

7. Test hole TX-10-To describe the extent of the anomaly, if present, east of the Madison River and to describe baseline conditions if not

8. Test hole TX-11-To evaluate the results of surface geophysical investigations and subsurface conditions at the site considered most favorable for a pumping test of the bedrock aquifer near the predicted locus of upwelling

9. Test hole TX-12-To verify the results of test hole TX-11 and to allow the pumping or flow tests of the bedrock aquifer (The test hole was drilled by the Montana Bureau of Mines and Geology after the termination of the investigation at the site suggested by the senior author.)

10. Shotholes SH-1 to SH-5-To describe subsurface conditions along seismic-refraction profiles

Despite various attempts, unstable soil conditions precluded the installation of test holes northeast of the spring, west of the Madison River. Shothole SH-5 was drilled after an interval of subfreezing weather but was inaccessible for deepening when drilling equipment was available.

In test holes TX-2 to TX-6, screened sand points were installed at the base of the casing to permit measurement of hydraulic head and collection of water samples representative of the open interval. The rest of the grouted test holes were completed without a screen, but the casing was subsequently perforated adjacent to selected coarse-grained strata to permit measurement of vertical variations in hydraulic head and collection of samples for chemical analysis.

In the vicinity of the hot spring, the valley fill penetrated by wells and test holes consists mainly of poorly consolidated, commonly calcareous, tuffaceous clay, silt, and argillaceous sand-all interbedded with lenticular layers of coarse sand and gravel. As much as $12 \mathrm{~m}$ of poorly consolidated alluvium, consisting largely of rounded cobbles, overlies the finer grained sediment at most of the drill sites. Installation of grouted conductor pipe through the unstable surficial sediment by local domestic well-drilling contractors using cabletool or air-rotary percussion equipment significantly increased the efficiency of the heavier mud-rotary equipment subsequently used to complete the deeper holes.

In the interest of economy, hardened drive shoes were installed on the 152-mm diameter conductor pipe in test hole TX-7 and in shotholes SH-1 and SH-3 to SH-5 to allow detonation of seismic-refraction charges below the casing without destroying the holes. Existing cased test holes along the profiles also were used as shotholes, although some were destroyed. Shotholes SH-3 and SH-4 subsequently were deepened for completion as temperature-gradient test holes, but damage to the casing by detonation or unstable soil conditions prevented access to the other holes.

The use of viscous and weighted drilling fluids (mud) to prevent the collapse of the holes, maintain circulation of drilling fluids, and control excessive pressure generally precluded measurement of water levels or collection of water samples at successive depths during drilling. Large-capacity air-rotary equipment capable of simultaneous drilling and driving of casing would, in most instances, have been more efficient than the mudrotary equipment used. A similarity in composition and appearance between the drilling mud and much of the fine-grained tuffaceous sediment, as well as recirculation of the coarse fraction, hindered the accurate differentiation of the penetrated section from the cuttings. The specific gravity, porosity, density, and in-place thermal conductivity were determined for core samples of representative intervals (table 1 ).

\section{BOREHOLE GEOPHYSICAL LOGGING}

Borehole geophysical logs included single-point resistivity and self-potential in the open holes and natural gamma ray (using a high-temperature probe) in both open and cased test holes, shotholes, and domestic wells. These logs provided the most useful data for description and correlation of the strata. However, large 
differences in the type and condition of the logging equipment and in the temperature and composition of the drilling fluids and rock caused considerable variation in the quality of the logs.

Many of the natural gamma logs more closely resembled the resistivity logs than the self-potential logs of the same holes. The anomalous response is attributed to the relatively substantial radioactivity of the crystalline bedrock and the coarse-grained sediment derived therefrom (figs. 6 and 7).

The geophysical logs confirm the lateral lithologic variability indicated by results of the surface geophysical and geologic methods. Although no persistent marker horizons, except the base of the surficial alluvium and the crystalline bedrock surface, were identified throughout the area, a somewhat tenuous correlation between unique strata in adjacent holes indicated minor $(20-\mathrm{m})$ displacements and gentle dips in the discontinuous strata. A bed of well-consolidated silt and clay, 10 to $15 \mathrm{~m}$ thick at the base of the valley fill in test holes TX-9 and TX-11, is a potentially extensive confining layer. The geologic structure, as inferred from the geologic and geophysical data, and subsurface temperatures along sections through the area are shown in figures 8 and 9.

\section{TEMPERATURE GRADIENTS AND HEAT FLOW}

Temperatures in wells, test holes, and shotholes of intermediate depth were measured at intervals of $3.1 \mathrm{~m}$ or less with a manually operated thermistor-Wheatstone bridge combination or a commercial digital thermometer and reel capable of measuring temperatures with a precision of about $0.1{ }^{\circ} \mathrm{C}$ at a depth of $305 \mathrm{~m}$. Excessively

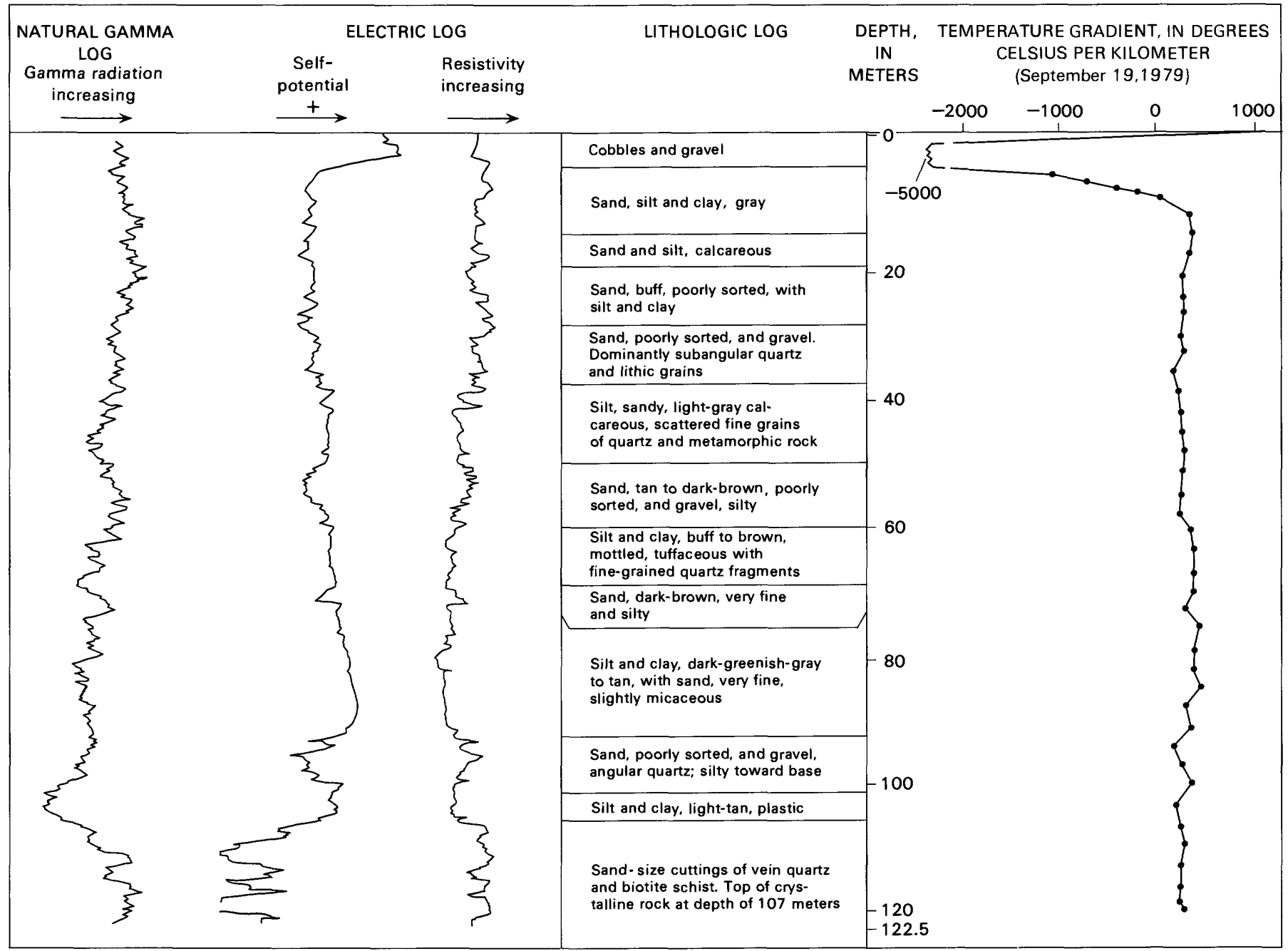

FIGURE 6.-Geophysical logs, lithologic summary, and temperature gradients for test hole TX-9. 
EVALUATION OF A HYDROTHERMAL ANOMALY NEAR ENNIS, MONTANA

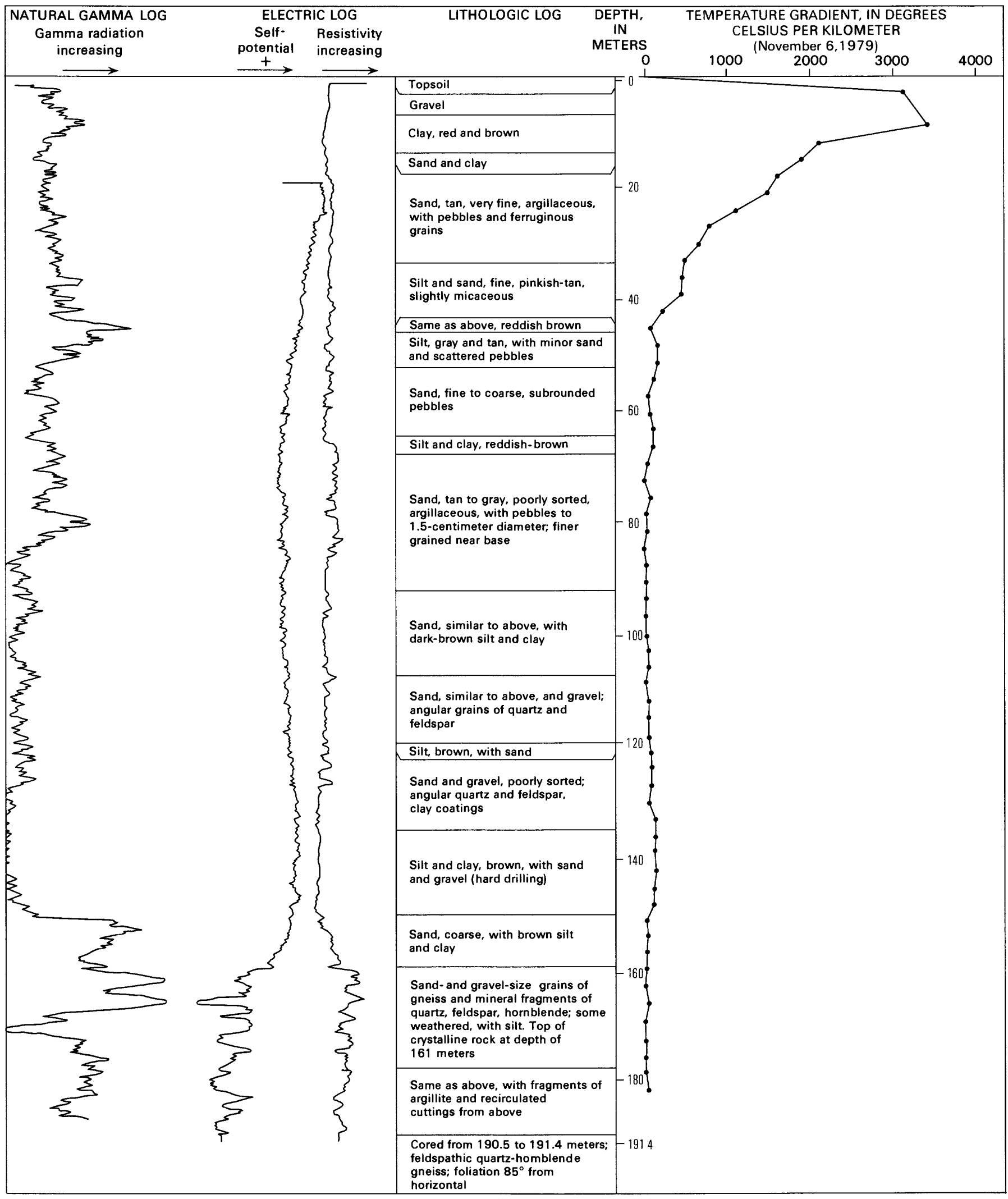

FIGURE 7.-Geophysical logs, lithologic summary, and temperature gradients for test hole TX-11. 


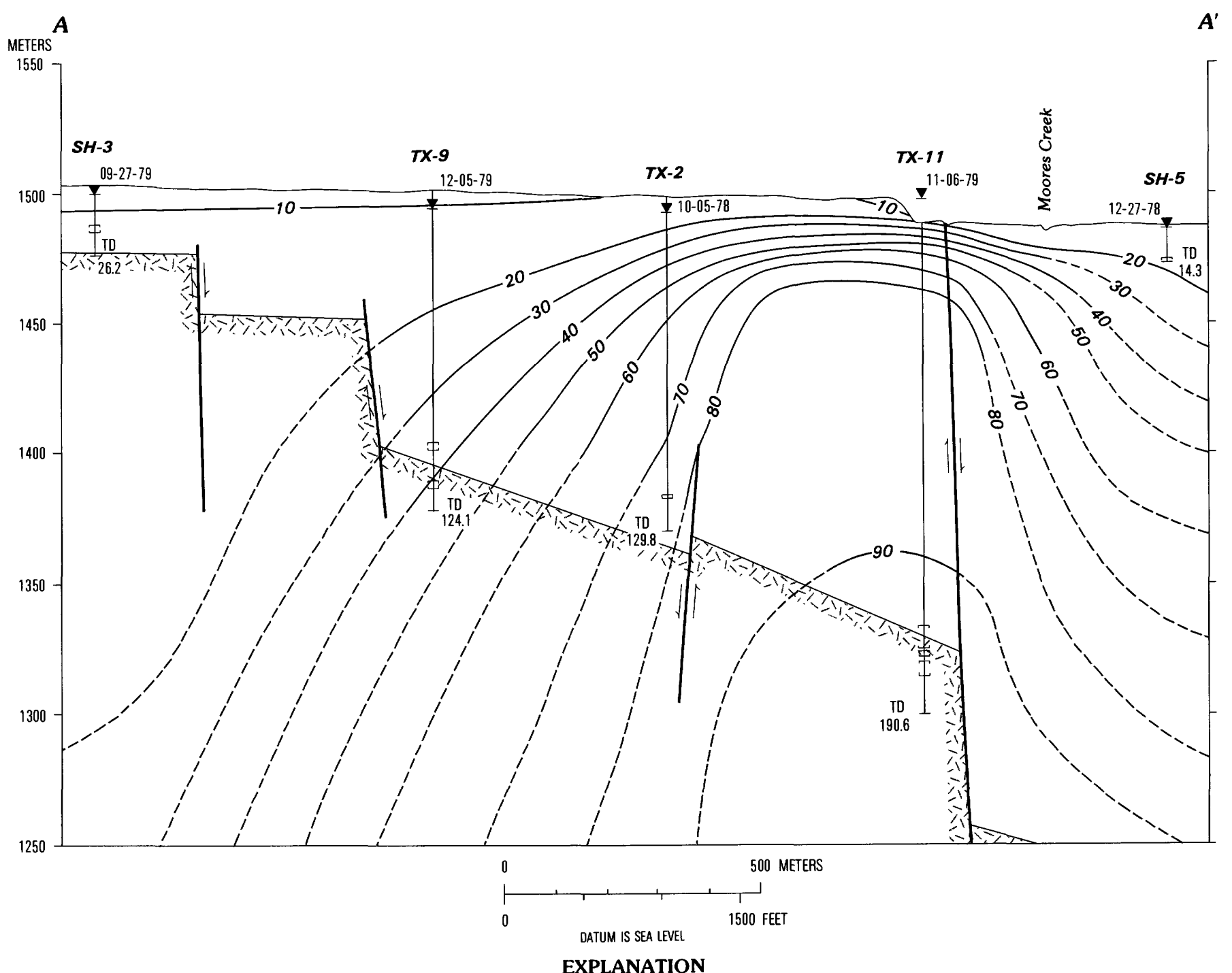

FIGURE 8.-Section $A-A$ ' showing configuration of bedrock surface, measured and estimated temperatures, and water levels between shotholes $\mathrm{SH}-3$ and SH-5. Trace of section shown in figure 3. Bedrock surface modified from seismic-refraction profile by C.J. Wideman (Montana College of Mineral Science and Technology, written commun., 1980). Vertical exaggeration $\times 5$.

viscous drilling mud and the need to minimize rig time thwarted most attempts to log during drilling, but the temperature of the circulating mud was monitored continuously to detect the presence and approximate depth of pressurized thermal zones. Most of the data included in table 2 were obtained from water-filled, grouted test holes. Under static conditions and after sufficient time had elapsed following drilling or pumping, the temperature logs presumably represent the natural temperature profiles. Increasingly smaller changes in successive profiles normally reflect the approach to thermal equilibrium. Wells other than test holes were logged under a variety of conditions; the resultant temperature-depth profiles might describe the transient effects of drilling or natural or pumped water circulation within or adjacent to the well bore. The most stable, complete, and representative profiles for the test holes are shown in figure 10. These profiles do not 
MEETESS

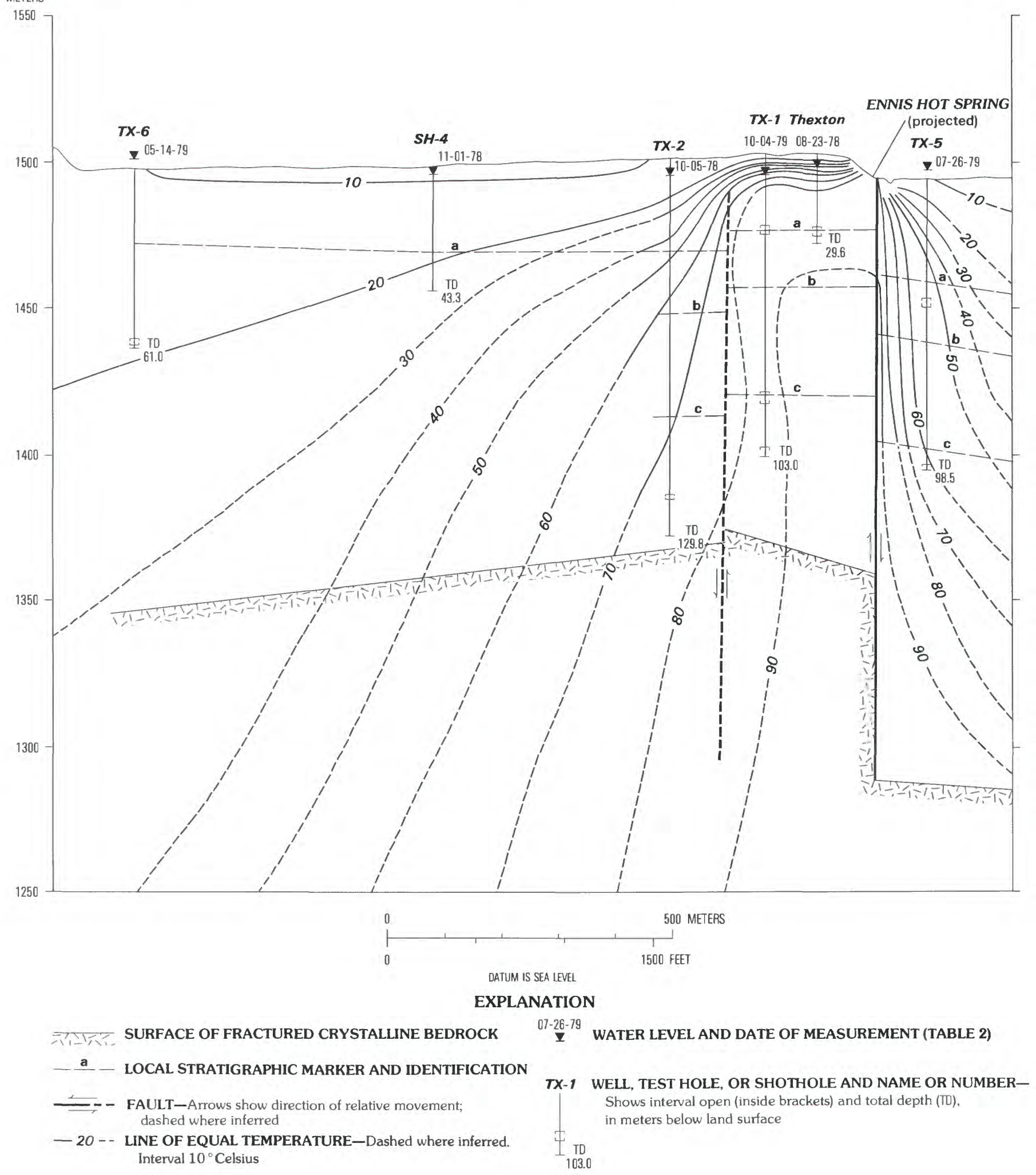

Figure 9.-Section $B-B$ ' showing configuration of bedrock surface, measured and estimated temperatures, and water levels between test holes TX-5 and TX-6. Trace of section shown in figure 3. Bedrock surface modified from seismic-refraction profile by C.J. Wideman (Montana College of Mineral Science and Technology, written commun., 1980). Vertical exaggeration $\times 5$. 


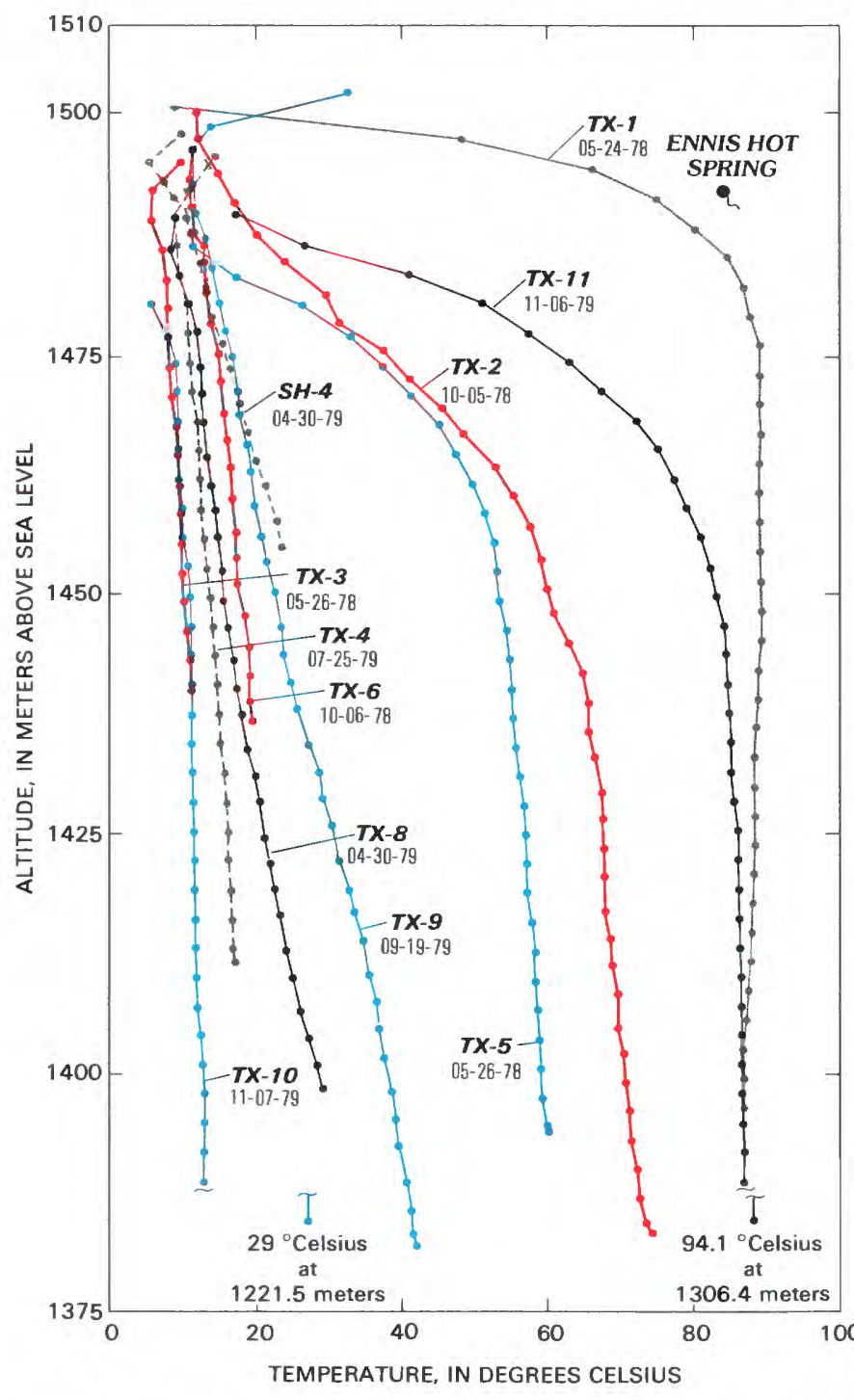

FIGURE 10.-Temperature-depth profiles for test holes (TX) and shotholes $(\mathrm{SH})$ in Ennis Hot Spring area.

necessarily show the maximum temperatures measured (table 2).

The temperature-depth profiles are used to estimate the magnitude, configuration, and local extent of the presumed thermal anomaly and lithologic and hydrologic boundaries. Temperature gradients in selected intervals are combined with thermal-conductivity values (table 1) to yield estimates of conductive heat flow. Because the density of water varies inversely with the temperature in the range measured, the temperature profiles are used to correct measured water levels in the thermal wells in accordance with standardized hydraulic-head values useful for estimating horizontal and vertical hydraulic gradients.

Temperatures in wells and test holes generally increased with depth; the maximum temperature was $94.1{ }^{\circ} \mathrm{C}$ in test hole TX-11 at a depth of $185.3 \mathrm{~m}$ in crystalline rock. The temperature gradient, which is the rate of change in temperature with depth, varied from test hole to test hole and with depth in each hole. Temperature gradients in the grouted test holes completed in the valley fill ranged from -35 to $323{ }^{\circ} \mathrm{C} / \mathrm{km}$ (table 2). The temperatures were determined principally by conductive heat flow through the rock or valley fill, convective flow (both lateral and vertical) in the circulating water, or a combination of the two processes.

The type of heat flow, whether conductive or convective, determines the shape of the profiles. The temperature-depth profiles in figure 10 can be grouped into two subsets: (1) those of test holes TX-1, TX-2, $\mathrm{TX}-5$, and TX-11, in which significant curvature indicates convective effects, and (2) the remainder of the profiles, which for the most part are rectilinear, indicating a predominantly conductive regime. Distortion of geochemical gradients by upwelling and lateral movement of thermal water between fractures in crystalline rock and permeable zones in valley fill limited the utility of temperature profiles for predicting temperatures at depths greater than the measured depth.

In downward succession, most of the profiles describe three distinct zones:

1. A zone of decreasing temperature between the land surface and the water level (absent in flowing wells)

2. A zone of increasing temperature in which the temperature-depth profile is downwardly concave and in which heat is largely dissipated by lateral movement of the ground water (This zone is less than $15 \mathrm{~m}$ thick in the cooler (less than $50^{\circ} \mathrm{C}$ ) test holes where it normally corresponds to a surficial layer of permeable coarse-grained fill, but the zone can exceed $50 \mathrm{~m}$ in thickness in the hot test holes, particularly those which could flow at the surface.)

3. A lower zone in which the profile is nearly rectilinear or consists of rectilinear segments corresponding to major depth intervals (This zone is mainly in stratified sediment containing clay layers that restrict vertical movement of water; therefore, vertical heat flow through the lower zone can be principally conductive.)

The intersections of the segments in zone 3 normally correspond to lithologic boundaries. Gradients representing adjacent measurements vary considerably, probably as a result of localized variations in lithology and lateral movement of water through permeable strata. However, the linear coefficients of determination between temperature and depth within the major intervals in zone 3 normally exceed 0.98 . The linearity indicates that a single (mean) value for the temperature 
gradient-the least-squares thermal gradient (Leonard and Wood, 1980a)-represents each of the major intervals and that heat flow is dominantly conductive.

The profiles in which the maximum temperature is less than $50{ }^{\circ} \mathrm{C}$ differ from those in which the maximum temperature is greater than $50{ }^{\circ} \mathrm{C}$. Upward extensions of the rectilinear parts of the profile in the cooler test holes intersect the land surface at temperatures less than $10{ }^{\circ} \mathrm{C}$-near the normal temperature of shallow ground water in the area $\left(6.4{ }^{\circ} \mathrm{C}\right)$. Conductive heat flow is nearly adequate to maintain thermal equilibrium. For the hotter test holes, the intersection with the land surface is at a higher temperature, the difference reflecting heat transfer by convective flow and dilution of the thermal water with colder water. Depth to the top of the dominantly conductive zone in the hotter test holes is variable; therefore, predictions based on extrapolation from shallow depth are normally misleading.

The temperature gradient below a depth of $40 \mathrm{~m}$ in test hole TX-11 before perforation was only about $75^{\circ} \mathrm{C} / \mathrm{km}$ (table 2). The upward extension of the rectilinear part of the curve intersects the land surface at about $83{ }^{\circ} \mathrm{C}$, the temperature of the hot spring (fig. 10). Unless the correspondence of the altitude and temperature of the hot spring along the extended profile for test hole TX-11 is coincidental, it constitutes evidence that the spring water was cooled by conduction instead of by a mixing with shallow ground water.

The profile for test hole TX-1 appears to typify a zone of vertical convective flow of thermal water, for example in a fault zone, with little or no heat loss by conduction. The highest temperature $\left(90.3{ }^{\circ} \mathrm{C}\right)$ was measured at a depth of $27.4 \mathrm{~m}$ (table 2), below which the thermal gradient was negative. As a result of faulty construction, circulation of thermal water in the annulus outside the casing is suspected. However, the temperature distribution is consistent with flow near the margin of a local convective cell, where the rising thermal water is replaced by cooler water of greater density.

The map showing the subsurface temperature at an altitude of 1,463 m (fig. 11) includes measured data from most of the test holes and wells. The map showing the depth at which the temperature is $40^{\circ} \mathrm{C}$ (fig. 12) is based on actual measurements and the extrapolation of temperature gradients. Both maps appear to describe the upward leakage of hot water into the valley fill in an approximately triangular area bounded by test holes $\mathrm{TX}-1, \mathrm{TX}-5$, and $\mathrm{TX}-11$, with a lateral plume of the thermal water along a northeasterly hydraulic gradient. The test-hole data indicate that the hydrothermal anomaly in the valley fill underlies an area of at least 300 ha.

The northwest trend of the lines south of the hot spring might indicate the existence of a transverse fault undetected by the geophysical surveys. Because the trend probably represents the contact between the upwelling thermal waters and cooler water flowing laterally from the southwest, it might have more hydraulic than structural significance. Water-level measurements support the hypothesis that the hot water in the Thexton well and in test hole TX-1 was emplaced by lateral, as well as vertical, movement from a locus east of the well and test hole; therefore, a fault affecting the valley fill at or near test hole TX-1 is consistent with the data.

Conductive heat flow is described by the equation

$$
Q=K \cdot G
$$

where $Q=$ heat flow, in milliwatts per meter squared; $K=$ thermal conductivity, in watts per meter per degree Celsius; and

$G=$ temperature gradient, in degrees Celsius per kilometer.

Thus, the temperature gradient varies directly with the rate of conductive heat flow and inversely with the thermal conductivity. $G$ is determined from the measured values of temperature and depth (table 2). Values for $K$ were determined for selected core samples using needle probes through small holes drilled in the sealed core barrels. The original moisture content was preserved. If the porosity was not materially affected by coring, the values reported in table 1 resemble more closely the in-place conductivity than the commonly quoted bulk (or solid component) conductivity of the geologic materials. According to D.D. Blackwell (Southern Methodist University, written commun., 1979), who tested the core samples, the in-place thermal conductivity of saturated material can be estimated from the bulk conductivity using the equation

$$
K_{i p}=K_{b}^{1-\phi} \cdot K_{w}^{\phi}
$$

where $K_{i p}=$ in-place thermal conductivity,

$K_{b}=$ thermal conductivity of the solid material,

$\phi=$ porosity, and

$K_{w}=$ thermal conductivity of water $(0.5858$ $\left.(\mathrm{W} / \mathrm{m}) /{ }^{\circ} \mathrm{C}\right)$.

For vertical conductive heat flow, $Q$ for each major interval is constant, and the thermal gradient varies inversely with the thermal conductivity.

Regional heat flow in southwestern Montana ranges from about 60 to $105 \mathrm{~mW} / \mathrm{m}^{2}$ (Sass and others, 1976); smaller or larger values can be considered anomalous. Blackwell and Chapman (1977) cited a $K$ of about 1.5 $(\mathrm{W} / \mathrm{m}) /{ }^{\circ} \mathrm{C}$ as representative of the valley fill in the Basin and Range province to the south (fig. 13), where the temperature gradient is about $57^{\circ} \mathrm{C} / \mathrm{km}$, and the normal regional heat flow is about $84 \mathrm{~mW} / \mathrm{m}^{2}$. They cited 


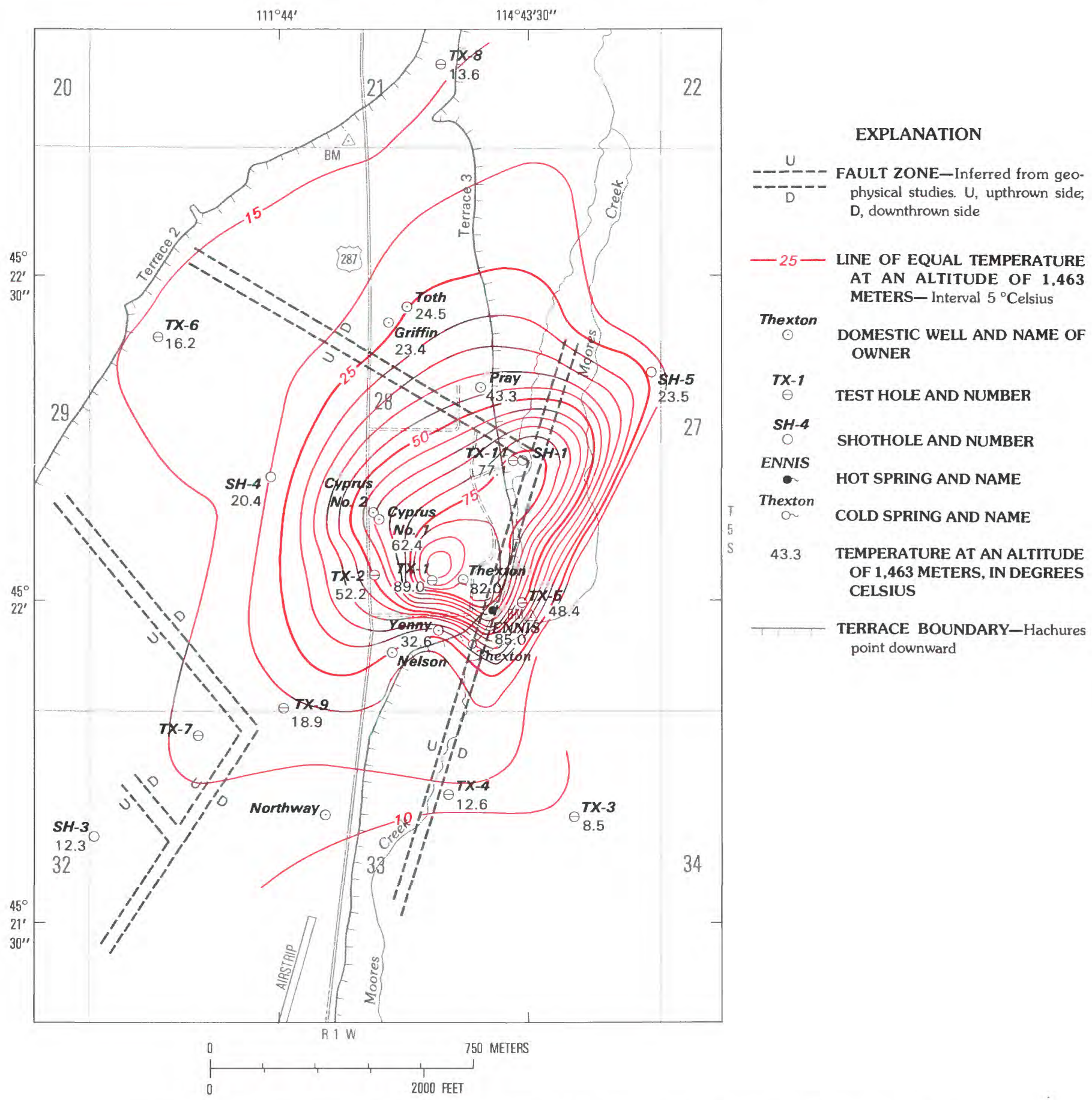

Figure 11.-Subsurface temperature at an altitude of 1,463 meters (about 30 meters below land surface).

corresponding values of $K=2.9(\mathrm{~W} / \mathrm{m}) /{ }^{\circ} \mathrm{C}$ and a temperature gradient of $27^{\circ} \mathrm{C} / \mathrm{km}$ for the bedrock. Nathenson and others $(1983$, p. 14$)$ cited a regional gradient of about $30^{\circ} \mathrm{C} / \mathrm{km}$ for southwestern Montana. Conductive heat flow alone in all nonflowing test holes west of the Madison River exceeds $120 \mathrm{~mW} / \mathrm{m}^{2}$; therefore, all nonflowing test holes are within a thermal anomaly.
The greatest rates of conductive heat flow may be in the cooler test holes where vertical convective heat flow appears to be minimal. For example, the temperature gradient in silt and clay in the interval between 60 and $90 \mathrm{~m}$ in test hole TX-9 is about $334^{\circ} \mathrm{C} / \mathrm{km}$, whereas the gradient in sand in the adjacent intervals is about 250 ${ }^{\circ} \mathrm{C} / \mathrm{km}$ (fig. 6). If $K$ equals $1.2(\mathrm{~W} / \mathrm{m}) /{ }^{\circ} \mathrm{C}$ for clay and 1.6 


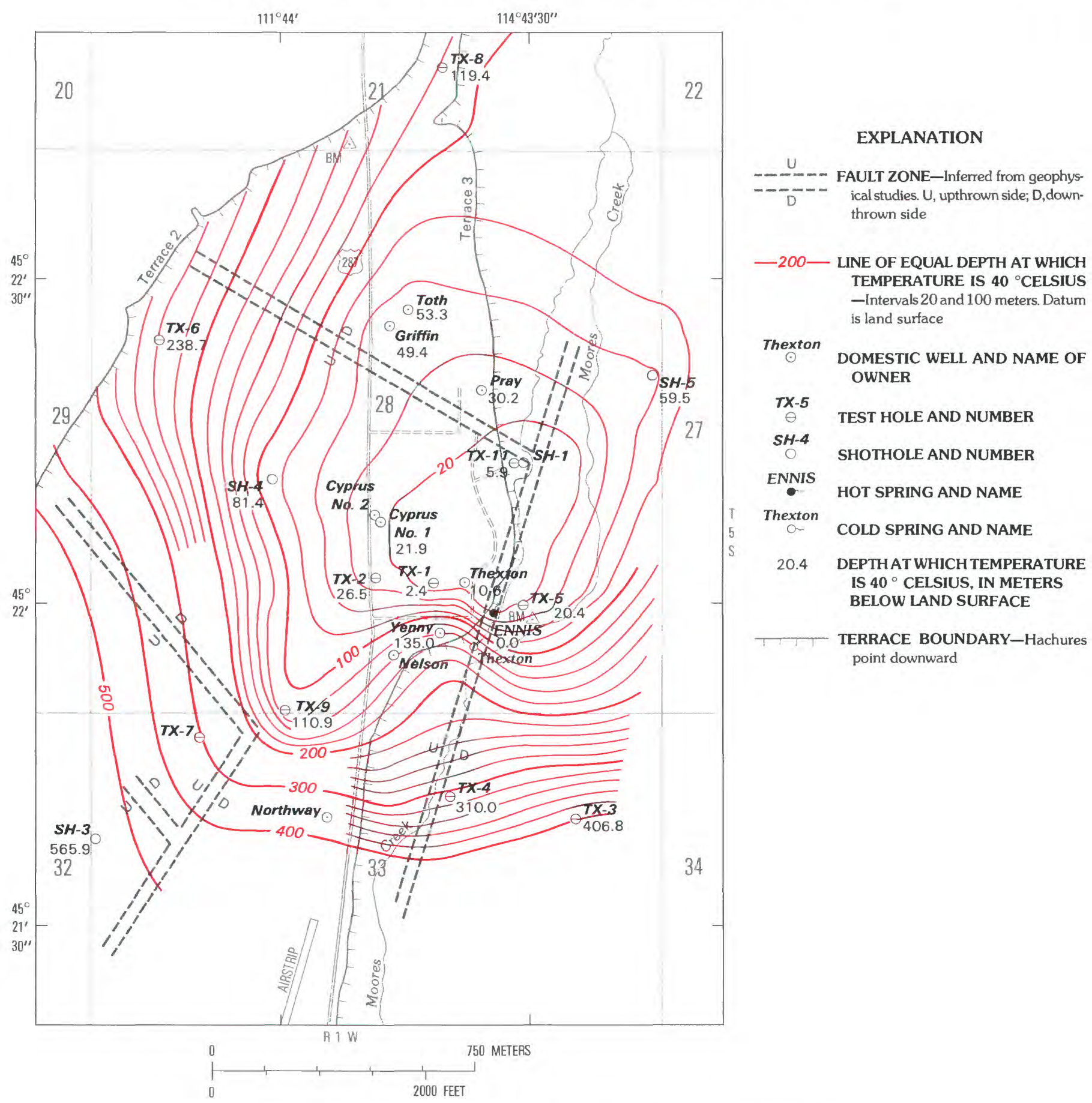

Figure 12-Depth at which the subsurface temperature is $40^{\circ}$ Celsius.

$(\mathrm{W} / \mathrm{m}) /{ }^{\circ} \mathrm{C}$ for sand (table 1$)$, the vertical heat flow through both intervals is about $400 \mathrm{~mW} / \mathrm{m}^{2}$. The gradient in schist and gneiss near the bottom of the hole is about $217^{\circ} \mathrm{C} / \mathrm{km}$, indicating a thermal conductivity of only about $1.8(\mathrm{~W} / \mathrm{m}) /{ }^{\circ} \mathrm{C}$ for the crystalline rock.

The configuration of the lines of equal temperature, based on the (tenuous) extrapolation of the temperature gradient in the crystalline rock, indicates a significant westward lateral component of heat flow between test holes TX-2 and TX-9 (fig. 8). The vertical exaggeration in figure 8 emphasizes the effect.

Temperature gradients in test hole TX-10, which is east of the river, are about $52{ }^{\circ} \mathrm{C} / \mathrm{km}$ to a depth of $137.2 \mathrm{~m}$ and $88^{\circ} \mathrm{C} / \mathrm{km}$ from $137.2 \mathrm{~m}$ to the total depth 


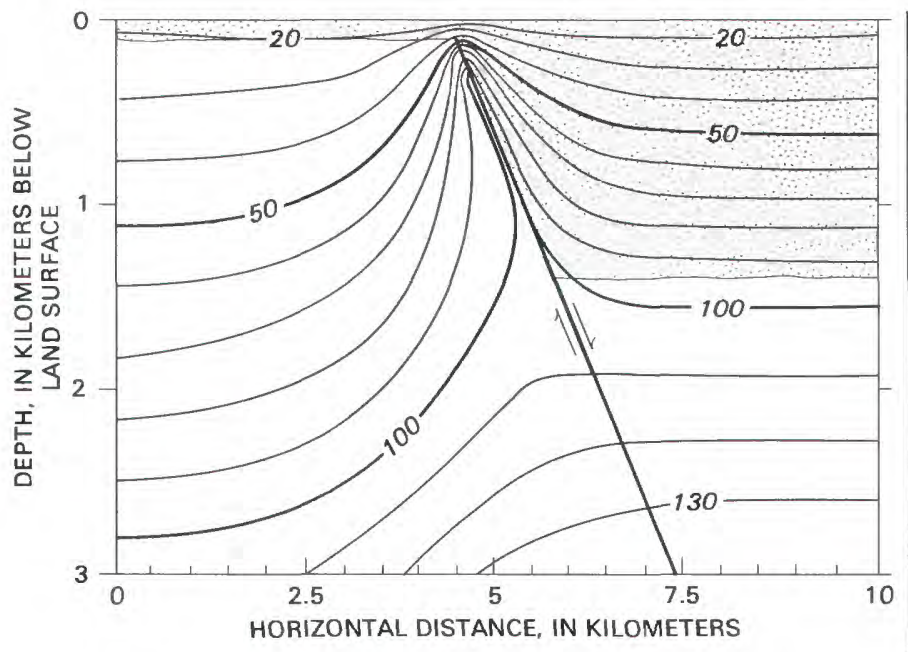

EXPLANATION

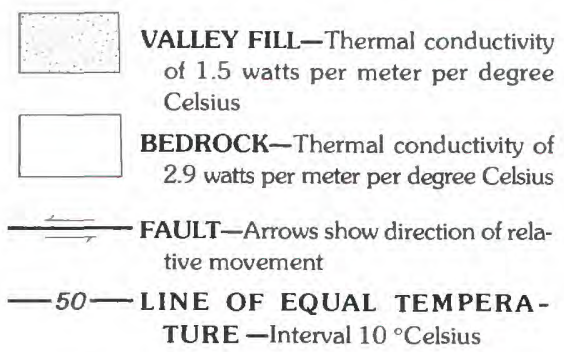

FigURE 13.-Thermal model of a hot spring in a basin-and-range setting. Modified from Blackwell and Chapman (1977, fig. 1), and published with permission. Vertical exaggeration $\times 2.5$.

of $258.5 \mathrm{~m}$. The temperature gradient in the lower part of test hole $\mathrm{TX}-10$ is considerably greater than the reported regional temperature gradient or maximum temperature gradients calculated for major depth intervals in similar valley fill in the Bitterroot Valley north of Medicine Hot Spring (fig. 1) (Leonard and Wood, 1980a). There, the temperature gradient normally decreased with depth.

If the gradient of $52{ }^{\circ} \mathrm{C} / \mathrm{km}$ for the upper part of the section were extrapolated below $137.2 \mathrm{~m}$, the estimated depth in test hole TX-10 to attain the maximum temperature of $94.1{ }^{\circ} \mathrm{C}$ measured in crystalline rock west of the river would be $1,648 \mathrm{~m}$. With the extrapolation of the temperature gradient of $88^{\circ} \mathrm{C} / \mathrm{km}$ in the lower part of the hole, the estimated depth to attain $94.1^{\circ} \mathrm{C}$ would be about $1,020 \mathrm{~m}$, which is near the bedrock surface estimated from regional gravity data (Burfeind, 1967). The correspondence might be coincidental, but the differences in calculated depths illustrate the hazards of extrapolation from shallow depth, even in the cooler test holes.

The relatively large gradient in the lower part of test hole TX-10 seems to indicate an eastward extension of the thermal anomaly; however, conductive heat flow might not exceed the regional value of about $105 \mathrm{~mW} / \mathrm{m}^{2}$. If values of $K=1.6(\mathrm{~W} / \mathrm{m}) /{ }^{\circ} \mathrm{C}$ for the upper, sandier section and $K=1.2(\mathrm{~W} / \mathrm{m}) /{ }^{\circ} \mathrm{C}$ for the lower, predominantly clay section apply (table 1), then the vertical conductive heat flow is about $84 \mathrm{~mW} / \mathrm{m}^{2}$ through the upper section and about $105 \mathrm{~mW} / \mathrm{m}^{2}$ through the lower section. If vertical flow through both sections was only equal to $84 \mathrm{~mW} / \mathrm{m}^{2}, K$ for the lower section would be about $1.0(\mathrm{~W} / \mathrm{m}) /{ }^{\circ} \mathrm{C}-$ a reasonable value for saturated clay (Robertson, 1979, fig. 10). However, for a flow of $105 \mathrm{~mW} / \mathrm{m}^{2}, K$ for the upper section would equal $2.0(\mathrm{~W} / \mathrm{m}) /{ }^{\circ} \mathrm{C}$, a value considerably larger than for cores with similar lithology west of the river. Even if the gradient in the upper part of the test hole is decreased somewhat by convection, test hole TX-10 appears to be near or beyond the eastern boundary of the anomaly.

Temperature gradients of 21 and $27{ }^{\circ} \mathrm{C} / \mathrm{km}$ (table 2) were measured in the McClellan No. 2 and Matzig wells completed in fractured metamorphic crystalline rock in the foothills southwest of the study area (fig. 2). Even if a liberal estimate of $K=3.0(\mathrm{~W} / \mathrm{m}) /{ }^{\circ} \mathrm{C}$ is assumed, heat flow is subnormal and is probably representative of a recharge area. Heat flow also appears to be subnormal in the valley fill penetrated by the Jeffers well adjacent to the Madison fault about $10 \mathrm{~km}$ east of Ennis (fig. 2). Although inconclusive, the combined evidence indicates that the ascending limb of the hydrothermal system associated with the hot spring is confined mainly to the western part of the valley and is overlain by valley fill.

\section{GEOHYDROLOGY}

Drillers' logs of existing wells in or near the study area indicated considerable lateral variation in lithology and depth to individual aquifers in the valley fill, variation in local artesian conditions, and a generally northeast flow of ground water toward the Madison River. Most of the wells were drilled with cable or air-rotary equipment to the minimum depths presumed necessary to achieve adequate yield for the expected demand and to exclude surface contamination. Reported yields of 3.2 to $6.3 \mathrm{~L} / \mathrm{s}$ from sand and gravel layers are common, as are reports of subsequent well failures caused by collapse and incursion of fine sediment. Scattered wells completed in the metamorphic rock exposed in the highlands to the east and west of the study area generally yield less than $1.3 \mathrm{~L} / \mathrm{s}$ from isolated fracture zones.

At the beginning of the investigation, a well (Thexton) about $100 \mathrm{~m}$ northwest of the spring supplied hot $\left(72^{\circ} \mathrm{C}\right)$ water from the valley fill for domestic purposes. During the investigation, thermal water was detected in six additional domestic wells in the study area. 
Reported yields were as much as $2.5 \mathrm{~L} / \mathrm{s}$. As soon as access was available, water levels and temperature gradients were measured, natural gamma logs were run, and water samples were collected from domestic wells for chemical analyses. These data supplement similar, more reliable data obtained under more controlled conditions from 41 shallow (depth of $2 \mathrm{~m}$ ) test holes and 16 thermal-gradient and seismic-refraction shotholes installed as part of the investigation. Most of the data are included in previous reports (Leonard and others, 1978; Leonard and Wood, 1980b). The most pertinent data are summarized in tables 1-3.

Water levels in test holes, shotholes, and domestic wells were measured soon after completion, and periodically during logging or sampling operations (table 2). Minor seasonal fluctuations reflect the effect of local recharge by rainfall, snowmelt, or irrigation. Major changes accompanied successive gun perforation of hydraulically discontinuous intervals in the grouted test holes. Attempts to isolate the perforated intervals were unsuccessful. Static water levels in the ungrouted domestic wells probably reflect the hydraulic head in the most permeable part of the open interval. Installation of multiple piezometers to enable direct measurement of hydraulic head at various depths at a site was beyond the resources of the investigation.

\section{SHALLOW DISCHARGE OF THERMAL WATER}

The terrace west of the spring (terrace 3 ) is generally dry and well drained. Several warm springs issue from the base of the surficial cobble layer about $6 \mathrm{~m}$ below the upper edge of the terrace, about $500 \mathrm{~m}$ north of the hot spring (fig. 14). Fluctuations of flow in response to rainfall and irrigation on the terraces indicate that the springs are discharge points for perched ground water. In contrast, the soil of the valley floor is commonly saturated near the surface, particularly in the vicinity of the hot spring. Calcareous efflorescence indicates that the surficial soils may conceal a linear area of upward discharge of thermal water, perhaps along the trace of a northeast-trending fault.

In Nevada, Olmsted (1977) used temperature surveys at a depth of $1 \mathrm{~m}$ to delineate temperature and heatflow anomalies at greater depths. To test the applicability of the method in the Ennis area, test holes were drilled on the flood plain to a depth of $2 \mathrm{~m}$ with a modified Giddings-type soil-sampling auger supplied by the Soils and Agriculture Department at Montana State University. Cobbles at the surface and shallow depth precluded use of the auger on the terrace west of the spring. Perforated plastic pipe $31.8 \mathrm{~mm}$ in diameter was installed to total depth. Water temperatures were measured with a thermistor-Wheatstone bridge combination capable of measuring temperatures with a precision of $0.1{ }^{\circ} \mathrm{C}$. Water levels were measured with a steel tape.

All bottom-hole temperatures exceeded $7.8{ }^{\circ} \mathrm{C}$, the highest temperature measured in the cold spring (Thexton) $122 \mathrm{~m}$ southwest of the hot spring. Water temperatures exceeding $15{ }^{\circ} \mathrm{C}$ remained constant during the fall, winter, and spring despite large variations in ambient air temperatures. The configuration of the thermal hines north of the cold spring reflects nearsurface discharge of thermal water along a northnortheast trend (fig. 14), probably the trace of a fault. The discharge of $1.2 \mathrm{~L} / \mathrm{s}$ measured at the hot spring probably represents a small percentage of the local discharge of thermal water.

The configuration of the local potentiometric surface (fig. 15) indicates that the warmed waters are not part of a single plume of thermal water from the hot spring, although the flow and configuration of the thermal anomaly may be governed in part by the orientation of permeable channels in the alluvium. The Thexton cold spring appears to be of shallow origin, relatively unaffected by deeper discharge of thermal water.

\section{WATER LEVELS AND DIREGTION OF FLOW IN VALLEY FILL}

Water levels in open domestic wells, test holes, and shotholes in the study area ranged from $12.3 \mathrm{~m}$ above land surface in test hole TX-11 to $8.8 \mathrm{~m}$ below land surface in test hole TX-9. Both test holes are completed in crystalline bedrock beneath a layer of wellconsolidated silt and clay at the base of the valley fill. Test holes TX-4, TX-5, TX-6, TX-10, and TX-11 and shothole SH-1 flowed at the land surface. The map of measured water levels (fig. 16) is not a true potentiometric map because of the large range of temperatures and of depths to open intervals. Furthermore, some test holes and shotholes were destroyed before others were constructed. However, the map is a useful tool to describe the apparent direction and magnitude of hydraulic gradients, particularly between test holes open at similar depths.

The hydraulic head in the individual sand and gravel lenses, separated by clay, increased with depth in virtually all the successfully cemented and perforated test holes. For example, a screened sand point was installed in a layer of sand and gravel at a depth of $97.2 \mathrm{~m}$ in test hole TX-5, about $100 \mathrm{~m}$ east of the hot spring. The static water level was about $3.5 \mathrm{~m}$ above the land surface. After perforation in the depth interval 40.5 to $42.7 \mathrm{~m}$, the water level declined about $4.8 \mathrm{~m}$, and the 
well no longer flowed. The apparent vertical hydraulic gradient between the sand point and the perforations is $0.085 \mathrm{~m} / \mathrm{m}$. Temperature logs indicated upward flow through the casing between the two open intervals.

The water level measured in shothole $\mathrm{SH}-1$, completed at a depth of $15.4 \mathrm{~m}$ in valley fill, is included in figure 16. This measurement probably better represents the water level in the valley fill than the corresponding measurement of the base of the valley fill or the fractured crystalline rock at a depth of about $157 \mathrm{~m}$ in test hole TX-11, about $10 \mathrm{~m}$ to the west. Based on the measured water level, the apparent vertical hydraulic gradient between the open intervals in the two holes is about $0.085 \mathrm{~m} / \mathrm{m}$, which is equal (at this level of precision) to the gradient in test hole TX-5.

In test hole TX-10 east of the river (fig. 2), pressurized grout and weighted drilling fluid were required to stanch a flow of $3.8 \mathrm{~L} / \mathrm{s}$ of cold water having a static head $5.8 \mathrm{~m}$ above the land surface. The source of the water was a sand and gravel layer penetrated at a depth of 26.0 to $33.5 \mathrm{~m}$. Recharge for the potentially prolific

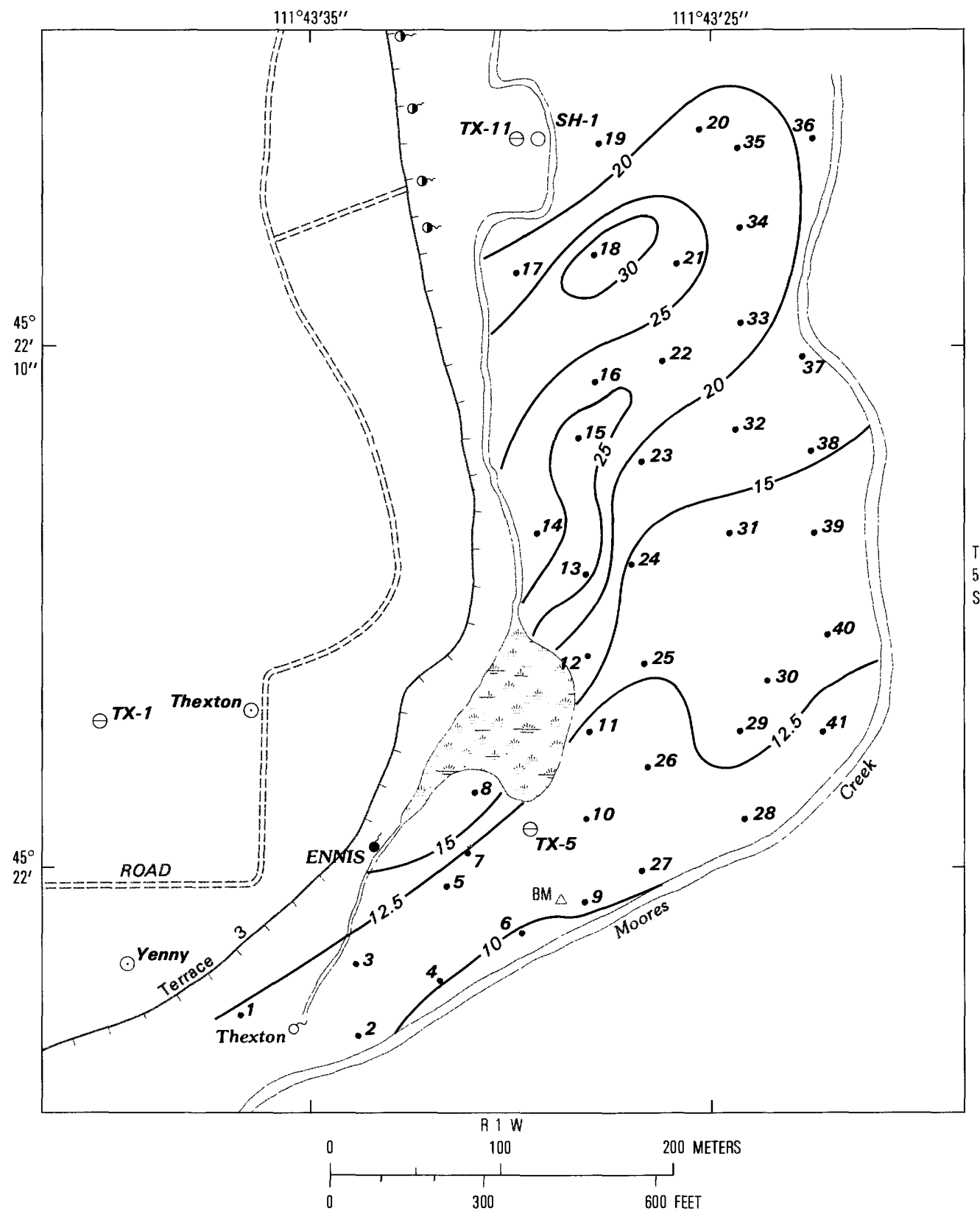

\section{EXPLANATION}

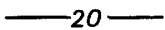

LINE OF EQUAL. TEMPERATURE AT A DEPTH OF 2 METERS BELOW LAND SURFACE-Intervals 2.5 and $5{ }^{\circ}$ Celsius

$$
.20
$$

SHALLOW TEST HOLE AND NUMBER

$$
\odot^{\text {Thexton }}
$$

DOMESTIC WELL AND NAME OF OWNER

$$
e^{T X-11}
$$

TEST HOLE AND NUMBER

$$
\mathrm{O}^{\text {SH-1 }}
$$

SHOTHOLE AND NUMBER

$$
\text { ENNIS }
$$

HOT SPRING AND NAME

$$
\text { Thexton }
$$

COLD SPRING AND NAME

WARM SPRING

TERRACE BOUNDARY-Hachures point downward

Figure 14.-Temperature in shallow test holes near Ennis Hot Spring, October 10, 1978. 
upper aquifer is probably streamflow near the upper boundary of alluvial fans along the west flank of the Madison Range. After perforation of the grouted casing opposite less permeable and more consolidated valley fill in the interval from 225.6 to $228.6 \mathrm{~m}$, the water level declined about $3 \mathrm{~m}$, and flow was less than $0.007 \mathrm{~L} / \mathrm{s}$. Lower water levels in test hole TX-10 than in wells and test holes west of the river and the decline in hydraulic head with depth indicate that test hole $\mathrm{TX}-10$ is east of the shallow hydrothermal anomaly.

\section{TEMPERATURE CORRECTIONS}

The decrease in density of thermal water with increasing temperatures significantly affects the water levels measured in the deeper, high-temperature (greater than $40{ }^{\circ} \mathrm{C}$ ) test holes. The measured water level in a hot well completed in an artesian aquifer would be higher than in the same well if the water were cool. Therefore, flow directions in an artesian aquifer with varying temperatures might not be perpendicular to the contours of a conventional potentiometric or water-level map based

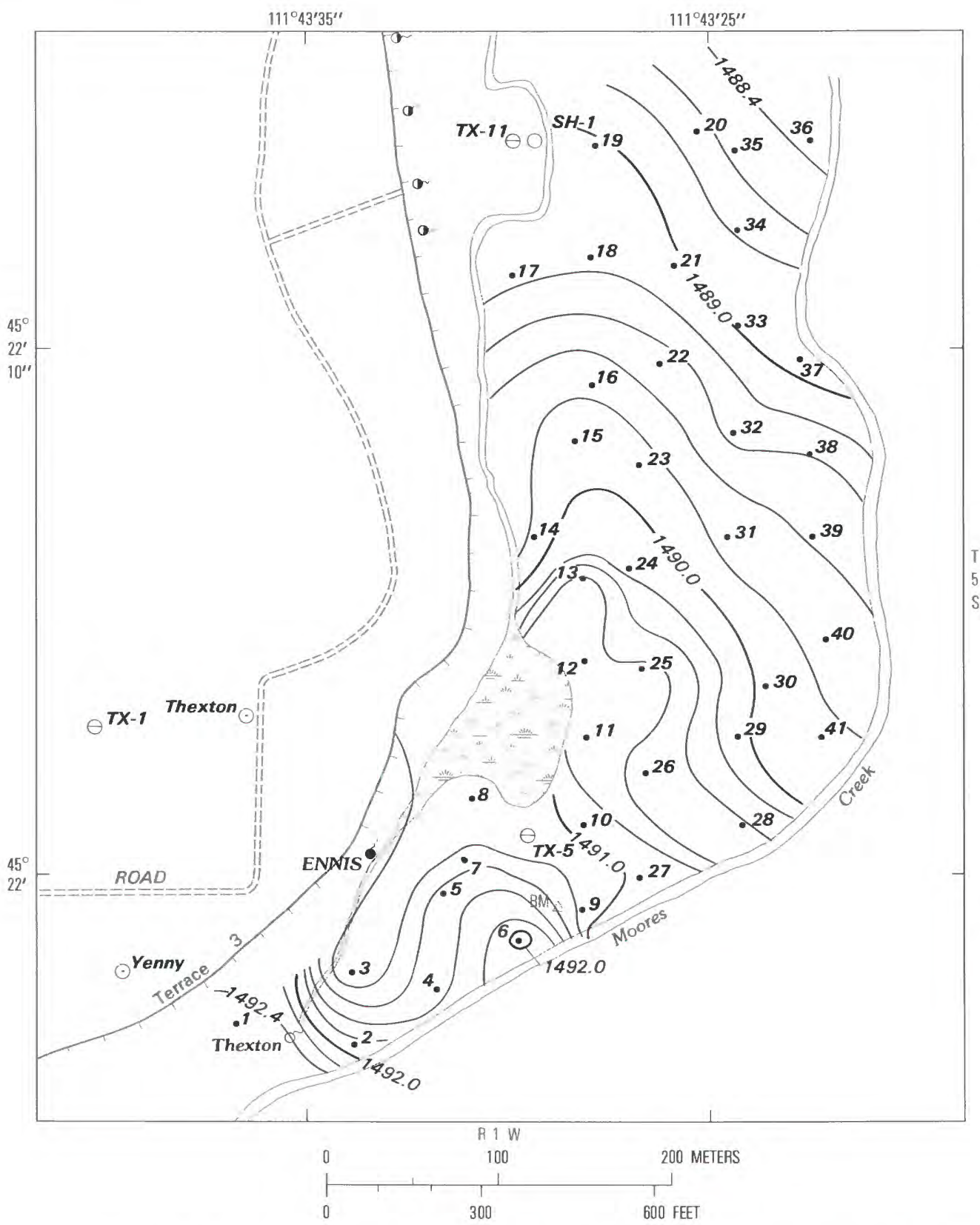

\section{EXPLANATION}

$-1491.0-$

WATER-LEVEL CONTOUR-Shows altitude of the potentiometric surface in test holes completed 2 meters be. low land surface. Contour interval 0.2 meter. Datum is sea level

$$
30
$$

SHALLOW TEST HOLE AND NUMBER

$$
\odot^{\text {Thexton }}
$$

DOMESTIC WELL AND NAME OF OWNER

$$
e^{T X-11}
$$

TEST HOLE AND NUMBER<smiles>[SiH3][Hg]</smiles>

SHOTHOLE AND NUMBER

$$
\text { - ENNIS }
$$

HOT SPRING AND NAME

$$
\text { Thexton }
$$

COLD SPRING AND NAME

$$
\text { a }
$$

WARM SPRING

TERRACE BOUNDARY-Hachures point downward

FIGURE 15.-Altitude of potentiometric surface in shallow test holes near Ennis Hot Spring, October 10, 1978. 
on measured values. To test the effect of temperature on the apparent hydraulic gradients shown in figure 16, the water levels were corrected to the levels to which water in the open intervals would rise if the temperature were $6.4{ }^{\circ} \mathrm{C}$, the average for cool ground water in the area. The altitude of the corrected water level is the equivalent cold-water hydraulic head, which is readily converted to units of pressure. Density differences caused by variations in the dissolved-solids concentrations in the study area are negligible.

The temperature correction is based on the assumption that the pressure $(P)$ at the open interval is

$$
P=\rho_{t} \cdot G \cdot L_{m}
$$

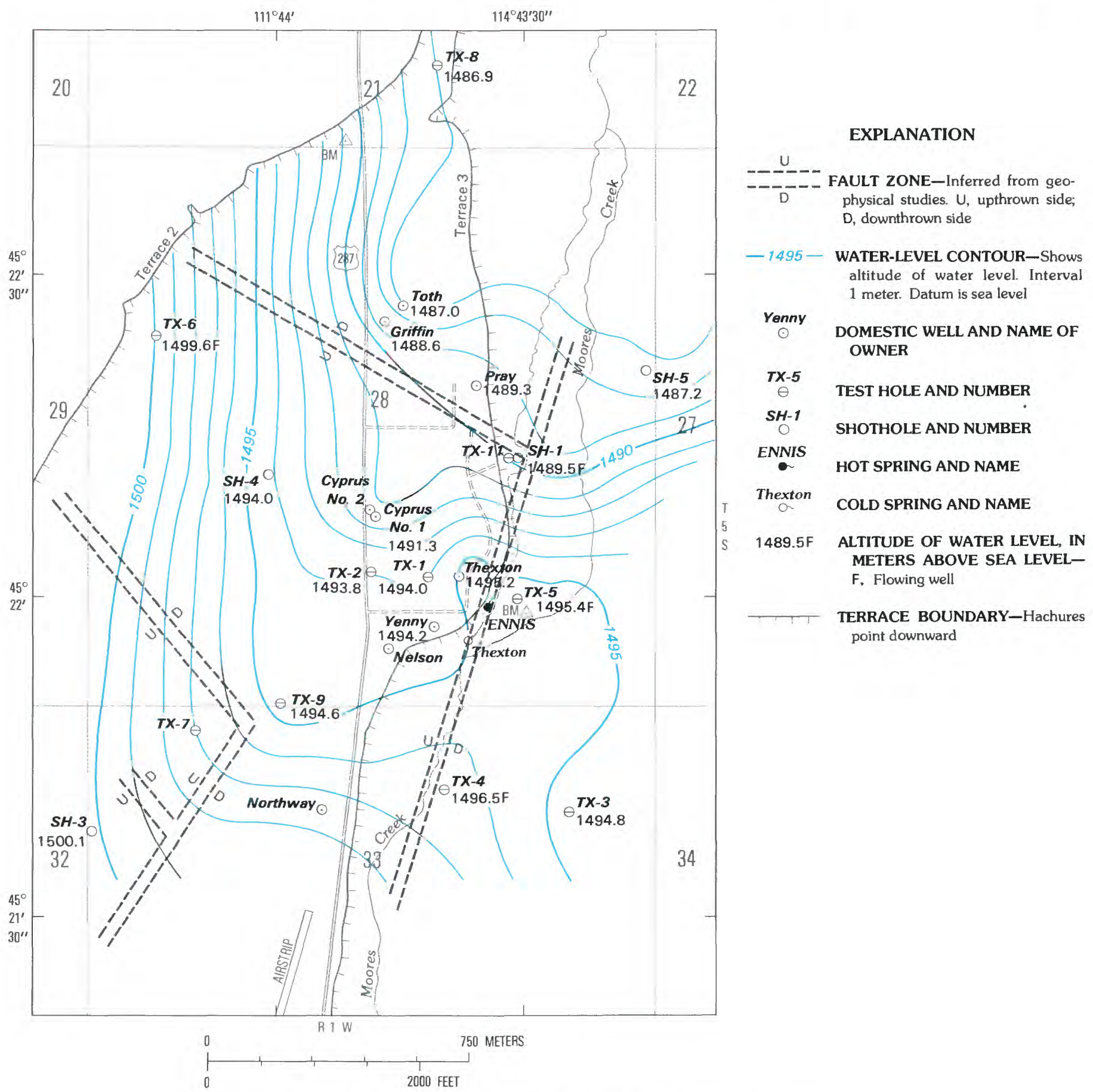

FIGURE 16--Uncorrected altitude of water levels in valley-fill deposits, 1978-79. 
where $\rho_{t}=$ density of the thermal water,

$G=$ gravitational constant, and

$L_{m}=$ length of the water column above the open interval.

The same pressure would be exerted by a shorter coolwater column of density $\left(\rho_{c}\right)$ and length $\left(L_{c}\right)$ :

$$
L_{c}=L_{m} \frac{\rho_{t}}{\rho_{c}}
$$

The altitude of the corrected water level or the equivalent cold-water head $\left(H_{c}\right)$ would be

$$
H_{c}=A_{b}+L_{c}
$$

where $A_{b}=$ altitude of the open interval.

Use of the correction and its significance are illustrated with temperature and water-level data from test holes TX-11 and TX-5.

On November 6,1979, 10 days after the completion of test hole TX-11, minor leakage from an unknown depth had raised the static water level to an altitude of $1,500.3 \mathrm{~m}$, which is $11 \mathrm{~m}$ above the land surface. The flow at the surface, less than $0.0002 \mathrm{~L} / \mathrm{s}$, caused no discernible deflection of the temperature profile. Temperatures ranging from 17.6 to $94.1^{\circ} \mathrm{C}$ were recorded for depth increments of $3.1 \mathrm{~m}$ or less from the land surface to the bottom of the hole at a depth of $182.9 \mathrm{~m}$ (altitude $1,306.4 \mathrm{~m}$ ) (table 2). A mean temperature of $10^{\circ} \mathrm{C}$ was assumed for the $11-\mathrm{m}$ water column above the land surface.

If $T_{1}$ and $T_{2}$ are the temperatures measured at the top and base of each increment $\left(D_{i}\right)$, the mean temperature, $T_{i}$, of each increment is

$$
T_{i}=\left(T_{1}+T_{2}\right) \div 2
$$

and the depth-weighted mean temperature $\left(T_{m}\right)$ of the entire column $\left(L_{m}\right)$ is

$$
T_{m}=\frac{\Sigma T_{i} D_{i}}{L_{m}}
$$

For the temperature profile measured on November $6,1979, T_{m}$ equaled $79.7^{\circ} \mathrm{C}$. The mean density of water at the temperature $\left(\rho_{t}\right)$ is $972.005 \mathrm{~kg} / \mathrm{m}^{3}(0.972005$ $\mathrm{g} / \mathrm{cm}^{3}$ ) (Hodgman and others, 1962, p. 2156). On the assumption that there is leakage at the base of the casing (altitude $A_{b}=1,306.4 \mathrm{~m}$ ), the length of the water column $\left(L_{m}\right)$ is $1,500.3-1,306.4=193.9 \mathrm{~m}$.

If the temperature of the water was $6.4{ }^{\circ} \mathrm{C}$, the density $\left(\rho_{c}\right)$ would be $999.946 \mathrm{~kg} / \mathrm{m}^{3}$, and the length of the equivalent column of cold water $\left(L_{c}\right)$ would be
$L_{c}=H_{m} \frac{\rho_{t}}{\rho_{c}} m=(193.9)(972.005 \div 999.946)=188.48 \mathrm{~m}$

Also, the altitude of the corrected water level or the equivalent cold-water head $\left(H_{c}\right)$ would be

$$
H_{c}=A_{b}+L_{c}=1,306.4+188.5=1,494.9 \mathrm{~m}
$$

This altitude is $5.4 \mathrm{~m}$ below the measured water level.

On November 29, 1979, temperature logs were made near the end of a 24-hour period during which test hole TX-11 flowed at the rate of $0.2 \mathrm{~L} / \mathrm{s}$ from perforations in the depth interval from 157 to $176.8 \mathrm{~m}$ (altitude $1,332.3$ to $1,312.5 \mathrm{~m}$ ). The uppermost perforations in the interval from 157 to $161 \mathrm{~m}$ might penetrate a basal layer of the valley fill below a confining layer (fig. 7), but the other perforations are opposite crystalline rock. After perforation, the hole was accessible for logging to a depth of only $158.5 \mathrm{~m}$ (table 2); therefore, the actual source of inflow could not be determined. The depthweighted mean temperature of the column of flowing water was $91.3{ }^{\circ} \mathrm{C}$, for which $\rho_{t}=964.439 \mathrm{~kg} / \mathrm{m}^{3}$. The static water level stabilized at $12.3 \mathrm{~m}$ (altitude $1,501.6$ $\mathrm{m}$ ) before declining about $1 \mathrm{~m}$ as the water in the upper part of the hole cooled. The cold-water equivalent head $\left(H_{c}\right)$ was $1,495.6 \mathrm{~m}$, which is $6.0 \mathrm{~m}$ below the measured hydraulic head. A nearly similar cold-water equivalent head of $1,495.8 \mathrm{~m}$ was calculated for perforations at a depth of $157 \mathrm{~m}$ using the temperatures and water levels measured under static conditions on November 6, 1979, when temperatures were assumed to have reached equilibrium. Leakage into the casing at this time was probably from approximately the same depth.

\section{DATUM CORRECTIONS}

Similar calculations for test hole TX- 5 before perforation yielded an equivalent head of $1,494 \mathrm{~m}$, indicating an apparent southerly gradient from test hole TX-11 to TX-5. However, the equivalent heads in the two test holes are not comparable because the altitudes of the open intervals differ. The uppermost perforations in test hole TX-11 were at an altitude of $1,332.3 \mathrm{~m}$, and the screen in TX-5 was at $1,394.6 \mathrm{~m}$. Correlative intervals in test hole TX-11 are separated by a confining layer of clay. Therefore, even the temperature-corrected hydraulic-head values probably do not describe true lateral hydraulic gradients between test holes.

As discussed earlier, hydraulic head in these and most other test holes completed in the valley fill increased with depth. A vertical hydraulic gradient of $0.085 \mathrm{~m} / \mathrm{m}$ was estimated for intervals of the valley fill in test holes 
TX-5 and TX-11. If effective over the interval $(62.3 \mathrm{~m})$ between the open zones in each well, this gradient alone would indicate that the equivalent hydraulic head in the valley fill in test hole TX-11 at the altitude of the screen in test hole TX-5 would be $1,491 \mathrm{~m}$-about $5 \mathrm{~m}$ less than the hydraulic head $(1,495.8)$ calculated for perforations at a depth of $157 \mathrm{~m}$ in test hole TX-11. That is, at the altitude of the perforations in test hole TX-5, the lateral component of flow apparently would be northward toward test hole TX-11. Data from other test holes were used to define the apparent directions of flow.

Most of the other test holes are only open in valley fill. Because the water columns above the open intervals differ in length and temperature and are of variable density, the hydraulic heads also must be corrected to a standard altitude (datum) to define the directions of flow (Jorgensen and others, 1982). A datum of 1,400 m above sea level was selected because it is near the open interval in most of the hot test holes where conditions inside and outside the casing can be assumed to be similar. The cold-water equivalent hydraulic heads then were calculated from the measured water levels and temperatures as if the casing were perforated at the datum.

Contours connecting the cold-water equivalent heads adjusted to the $1,400-\mathrm{m}$ datum are included in figure 17 . The contours appear to confirm a steep westerly gradient between test hole TX-5 and TX-1 at an altitude of $1,400 \mathrm{~m}$ in the valley fill.

For most of the test holes, the assumption that the calculated pressure at the datum altitude varied only hydrostatically from pressure in the perforated interval is probably valid. Corrections were negligible for test holes in which the temperature did not exceed $40{ }^{\circ} \mathrm{C}$. However, for test hole TX-11, in which the uppermost perforations are $67.7 \mathrm{~m}$ below the datum and in which temperatures ranged from 10 to $94{ }^{\circ} \mathrm{C}$, the pressures inside and outside the casing at the datum probably differ.

Using the measured water level $(1,500.27 \mathrm{~m})$ and temperature distribution in test hole TX-11 on November 6,1979 , the calculated cold-water equivalent hydraulic head at an altitude of $1,400 \mathrm{~m}$ (depth of about $89 \mathrm{~m}$ ) apparently was $1,498.1 \mathrm{~m}-2.3 \mathrm{~m}$ higher than for the perforations at an altitude of $1,332.2 \mathrm{~m}$ (depth $157 \mathrm{~m}$ ) and far higher than in any of the adjacent test holes. The difference obviously did not cause downward flow in the casing of the shut-in test hole. Under static conditions, hydraulic head (not pressure) at all points in the casing is constant. Instead, the difference is the result of differing lengths and temperatures of the water columns subject to correction between the water level and depths of 89 and $157 \mathrm{~m}$, respectively.

Previously described data from test hole TX -5 and shothole SH-1 indicate a negative (upward) vertical gradient of about $0.085 \mathrm{~m} / \mathrm{m}$ at the ambient temperatures. Applying this gradient (corrected for density) across the depth interval from 89 to $157 \mathrm{~m}$ in test hole TX-11 results in a decrease of $5.6 \mathrm{~m}$ in the adjusted cold-water equivalent hydraulic head to the posted value of 92.5 , only $3 \mathrm{~m}$ above the land surface.

According to the configuration of the contours in figure 17, the hot spring is along the axis of a ridge of relatively high hydraulic head approximately coincident with the postulated north-trending fault. The map shows the potential for lateral flow at the 1,400-m level (near the total depth of test holes TX-5 and TX-1) toward the west between the hot spring and test hole TX-1 and toward the north between test holes TX-5 and TX-11. As a result of the inaccessibility to heavy drilling equipment, which precluded the deepening of the shallow (depth $14.3 \mathrm{~m}$ ) shothole $\mathrm{SH}-5$, and mechanical problems that prevented reentry and additional perforation of test hole TX-11, the hydraulic head at or near the 1,400-m level in the valley fill northeast of the hot spring and west of the Madison River could not be measured.

The configuration of the depth lines to the temperature of $40{ }^{\circ} \mathrm{C}$ (fig. 12) and of the contours of the coldwater equivalent hydraulic heads (fig. 17) seems consistent with upward leakage of hot water from the crystalline rock into the valley fill near the hot spring. The somewhat similar configuration of Bouguer gravity (fig. 3) indicates a bedrock source, as do the high temperature and hydraulic head measured in test hole TX-11, sited on the upthrown block near the intersection of faults or scarps defined by surface geophysics.

Core samples of the fractured hornblende gneiss and gun perforation of the grouted casing in test hole TX-11, fortuitously opposite permeable zones, indicated that the rock was greatly fractured and that the test hole was indeed located near the postulated fault(s). Conditions similar to those found in test hole TX-11 can be anticipated in the crystalline rock along the north-trending fault and in permeable zones in the valley fill adjacent to the rock.

Lateral emplacement of thermal water in permeable zones in valley-fill aquifers that intersect a common conduit from the crystalline bedrock is indicated by the following:

1. The location of the hot spring along a line of flowing wells, including test holes TX-4 and TX-11

2. The increase in hydraulic head with depth in adjacent nonflowing test holes

3. The westward hydraulic gradient between the hot spring and test hole TX-1

4. The negative temperature gradient in test hole TX-1 Because the thermal waters appear to originate from a common conduit or interconnected conduits, interference among pumping or flowing wells installed near 
the faults can be anticipated. A decrease in hydraulic head by pumping or sustained flow of hot water could reverse or diminish the flow of hot water into the valley fill, thereby decreasing the flow of the hot spring and inducing the flow of cool water into peripheral wells. A decrease in the temperature of the hot spring to $75.5^{\circ} \mathrm{C}$ during March 1980 (Leonard and Wood, 1980b, p. 9) after test hole TX-11 had flowed for several weeks may illustrate the effect.

The site of a large-diameter well (TX-12) was selected on the terrace about $260 \mathrm{~m}$ south-southwest of test hole TX-11 to verify the results of TX-11 and the

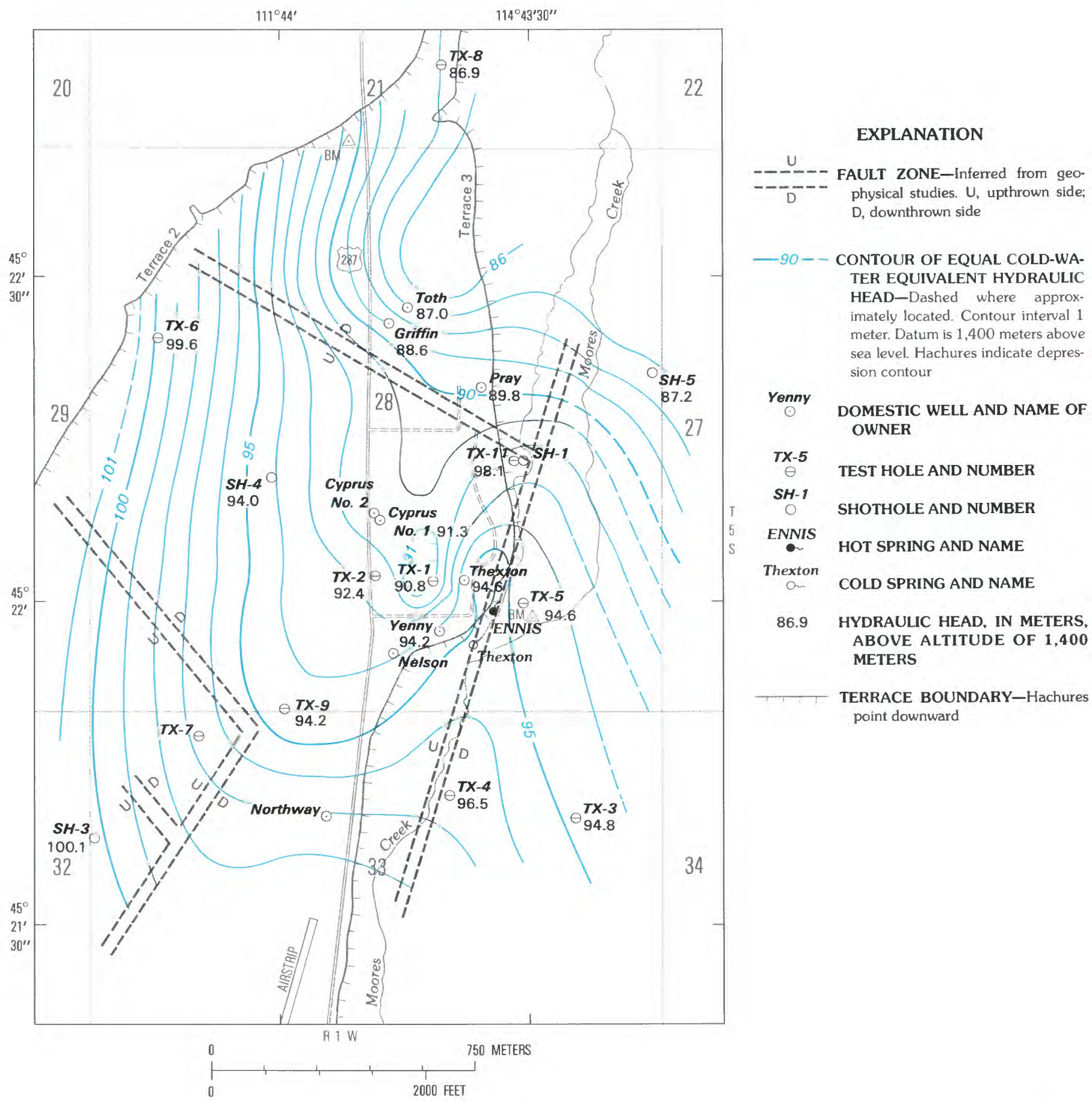

FIGURE 17.-Cold-water equivalent hydraulic heads in valley fill adjusted to a datum of 1,400 meters above sea level, 1978-79. Hydraulichead data were corrected for test holes in which the temperature exceeded $40{ }^{\circ} \mathrm{Celsius}$. 
geophysical surveys, and to pump and test the flow of the bedrock aquifer. The well was drilled and tested by the Montana Bureau of Mines and Geology during 1982 after completion of the investigation described in this report.

Sonderegger and Zaluski (1983) reported completion of well TX-12 to a depth of $291 \mathrm{~m}$ and of a privately drilled well (MAC-1) about 75 m north-northwest of test hole TX-11 to a depth of $366 \mathrm{~m}$, both in fractured gneiss and schist. The maximum reported temperatures of $92{ }^{\circ} \mathrm{C}$ at a depth of $150 \mathrm{~m}$ in well TX-12 and $97{ }^{\circ} \mathrm{C}$ at a depth of $335 \mathrm{~m}$ in MAC-1 are reportedly associated with well-defined fracture zones. Hydraulic connection between the test hole and the two wells was established during a pumping test of MAC-1 in which the reported transmissivity in the crystalline rock was $370 \mathrm{~m}^{2} / \mathrm{d}$ and the storage coefficient $2.5 \times 10^{-4}$. The projected sustained flow from well TX-12 was about $8.2 \mathrm{~L} / \mathrm{s}$ (J.L. Sonderegger, Montana Bureau of Mines and Geology, oral commun., 1984).

The information is consistent with the interpretations based on the earlier data. Considerable variation in the spacing and degree of fracturing in surface exposures of similar rock indicates that the permeability of the crystalline aquifer can vary greatly with depth and from well to well depending on the nature and number of fractures in the open intervals.

\section{GEOCHEMISTRY}

Most natural hot-spring water in Montana and elsewhere appears to be meteoric water heated by deep circulation (White, 1973; Muffler, 1979; Chadwick and Leonard, 1979). During circulation, thermal water leaches soluble ions from the rock and is enriched in the heavier stable isotopes. The chemical composition of the water changes along the flow paths in response to temperature- and pressure-dependent reactions between dissolved constituents in the water and minerals in the rock and soil. Because the changes are somewhat predictable, the results of chemical analyses of samples of water and associated gases from springs, wells, and test holes are used to impose additional constraints on the conceptual model of the hydrothermal system described by the geologic, hydrologic, and geophysical data.

\section{SAMPLE COLLECTION AND PROCESSING}

Most of the water and gas samples were collected and processed for analysis by the central laboratory of the U.S. Geological Survey in Denver, Colo., or by USGS research laboratories in Menlo Park, Calif. Techniques outlined by Presser and Barnes (1974) or as specified by the receiving laboratories generally were used to minimize reactions that would alter the in-place character of the samples.

The $\mathrm{pH}$, specific conductance, and alkalinity of most water samples were determined at the sampling site. Samples of water normally were collected only after these characteristics remained relatively constant with pumping. Differences between onsite and laboratory determinations attest to the instability of many samples, particularly those obtained by airlift from nonflowing test holes. Filtered samples of thermal water were diluted to preclude precipitation or polymerization of silica.

Samples from some of the wells and test holes might represent the water only in the limited parts of the heterogeneous aquifers opposite the perforations or well points or might have contained drilling fluid. Alteration or destruction of many of the wells and test holes during the investigation precluded the replication of samples for comparison.

\section{CHEMICAL CHARACTERISTICS OF THE WATER}

Results of most of the analyses of samples collected in the Ennis area are reported in detail by Leonard and others (1978) and Leonard and Wood (1980b). Selected data are summarized in table 3.

\section{STABLE ISOTOPES}

The hydrogen-isotope ratio $(\mathrm{dD}$, in parts per thousand using the standard delta notation) in one sample $(\mathrm{dD}=-154.7)$ and the oxygen-isotope ratios in two samples $\left(\mathrm{d}^{18} \mathrm{O}=-19.09,-18.74\right)$ from Ennis Hot Spring are within the range of values determined for other thermal springs in Montana (Mariner and others, 1976; Leonard and others, 1978; Leonard and Wood, 1980b). A relatively small oxygen shift $(+1.46)$ from the meteoric water line (Craig, 1961) and a relatively small concentration of dissolved solids probably indicate a meteoric origin of the water with relatively minor water-rock interaction.

Similar properties characterize hot springs that issue from fractured crystalline rock in southwestern Montana. Mariner and others $(1976$, p. 25$)$ suggested that such springs might be relatively old and that the conduits have been flushed of the heavier oxygen isotopes. The data indicate similar reservoir conditions for Ennis Hot Spring; however, the concentrations of chloride and silica are larger than in the other springs.

\section{GASES AND RADIOACTIVITY}

Doering and Friedman (1980) reported abnormally large concentrations of helium in water samples from 
Ennis Hot Spring and the Pray domestic well. Subsequent samples of gas that bubbles from Ennis Hot Spring and test hole TX-11 (Leonard and Wood, 1980b) were suspected of having been contaminated with air as a result of failure of the sampling syringes, but the samples from test hole TX-11 contained concentrations of helium (0.5 to 1.3 percent) far in excess of normal values. The helium might constitute additional evidence for a deep-seated geothermal system in fractured crystalline rock.

As stated by R.H. Mariner (U.S. Geological Survey, written commun., 1980), "The relatively large helium content, almost certainly, must originate from radioactive decay in the basement rock, although leakage from the mantle cannot be ruled out without isotopic data." Radioactive decay might be a major source of the geothermal heat (Tilling and Gottfried, 1969; Blackwell and Robertson, 1973; Gabelman, 1976), but further study of this aspect was beyond the scope of this investigation. The source of the helium in test hole TX-11 is probably the fractured gneiss, as evidenced by the abnormally large response of the natural gamma logs, but the water is not anomalously radioactive.

Analyses by the Montana Department of Health and Environmental Sciences (Larry Lloyd, written commun., 1978, 1980) indicate that the gross alpha activity of the hot spring ranged from 4.0 to $4.4 \mathrm{pCi} / \mathrm{L}$ (picocuries per liter) and the gross beta activity from 13 to $21 \mathrm{pCi} / \mathrm{L}$. A water sample collected from test hole TX-11 on March 24, 1980, had a gross alpha activity of $1.5 \mathrm{pCi} / \mathrm{L}$ and a gross beta activity of $16.4 \mathrm{pCi} / \mathrm{L}$. The activities of a cool-water sample collected from test hole $\mathrm{TX}-10$ on the same day were $0.92 \mathrm{pCi} / \mathrm{L}$ for gross alpha and $14.7 \mathrm{pCi} / \mathrm{L}$ for gross beta. The maximum contaminant levels for public water supplies specified by the U.S. Environmental Protection Agency (1977) are $15 \mathrm{pCi} / \mathrm{L}$ for gross alpha and $50 \mathrm{pCi} / \mathrm{L}$ for gross beta. Much greater values have been determined for samples from other Montana hot springs (Leonard and Janzer, 1978; Leonard and others, 1978, p. 59).

Water from test hole TX-5 effervesced when pressure was released after the flowing well was shut in for several days. Hydrogen comprised about 89 percent of a gas sample collected on January 15,1979 , before perforation of a shallower interval relieved pressure in the casing. Reactions between the water and the iron pipe, electrolysis, or reactions involving mafic rock or organic material at depth were considered, but the source of the hydrogen remains unknown.

\section{DISTRIBUTION OF MAJOR IONS}

The concentration of dissolved solids in two samples from Ennis Hot Spring (table 3) ranged from 992 to
$1,030 \mathrm{mg} / \mathrm{L}$ (milligrams per liter). The concentration of dissolved silica is about $100 \mathrm{mg} / \mathrm{L}$. Sodium is the dominant cation; the anions are mixed. The relatively large concentration of chloride $(120 \mathrm{mg} / \mathrm{L})$ indicates that the hot spring is part of a convective hot-water (as opposed to vapor-dominated) system for which the chloride concentration normally exceeds $50 \mathrm{mg} / \mathrm{L}$ (White, 1973, p. 82).

The solubility of most minerals (with the notable exception of calcium carbonate) increases with temperature; therefore, thermal water normally contains larger concentrations of dissolved solids and heavier isotopes leached from the rock than does the cooler, local ground water. In the Ennis Hot Spring area, the thermal waters of deep-seated origin are readily distinguishable from the local ground water by the differing concentrations and distributions of the ions. In general, the concentration of dissolved solids becomes greater with increasing temperature.

In an accurate water analysis, the sum of the concentrations of the positive ions (cations) equals the sum of the negative ions (anions) when both are expressed in meq/L (milliequivalents per liter; reacting values). The concentration of a given ion then can be expressed as a percentage of the cations or anions. For example, the concentration of calcium can be expressed as a percentage of the cations as follows:

Percent $\mathrm{Ca}^{2+}=\mathrm{Ca}^{2+} \times 100 /\left(\mathrm{Ca}^{2+}+\mathrm{Na}^{+}+\mathrm{K}^{+}+\mathrm{Mg}^{2+}\right)$

where concentrations are given for calcium $\left(\mathrm{Ca}^{2+}\right)$, sodium $\left(\mathrm{Na}^{+}\right)$, potassium $\left(\mathrm{K}^{+}\right)$, and magnesium $\left(\mathrm{Mg}^{2+}\right)$. Most of the analyses of water samples from the wells and springs, expressed as percentages, plot within three well-defined fields on the trilinear diagram (Piper, 1944) in figure 18.

Calcium and magnesium comprise more than 60 percent of the cations in field $A$, which includes the shallow and cool ground water. Bicarbonate plus carbonate $\left(\mathrm{CO}_{3}+\mathrm{HCO}_{3}\right)$ comprises more than 50 percent of the anions.

Sodium comprises more than 90 percent of the cations in fields $B$ and $C$, which include deeper and warmer waters and possible mixtures of cool and thermal water. Bicarbonate plus carbonate is the principal anion in field $B$ but, comprises less than 50 percent of the anions in field C, which includes samples of the hottest water.

Samples of the thermal waters included in field $C$ are characterized by much larger concentrations of dissolved solids other than calcium and magnesium than are the samples in the other fields. In table 3, field C is subdivided into two parts: One part includes water from nonflowing sources having measured concentrations of dissolved solids less than $950 \mathrm{mg} / \mathrm{L}$ and of silica less than $80 \mathrm{mg} / \mathrm{L}$, and the other part includes water 


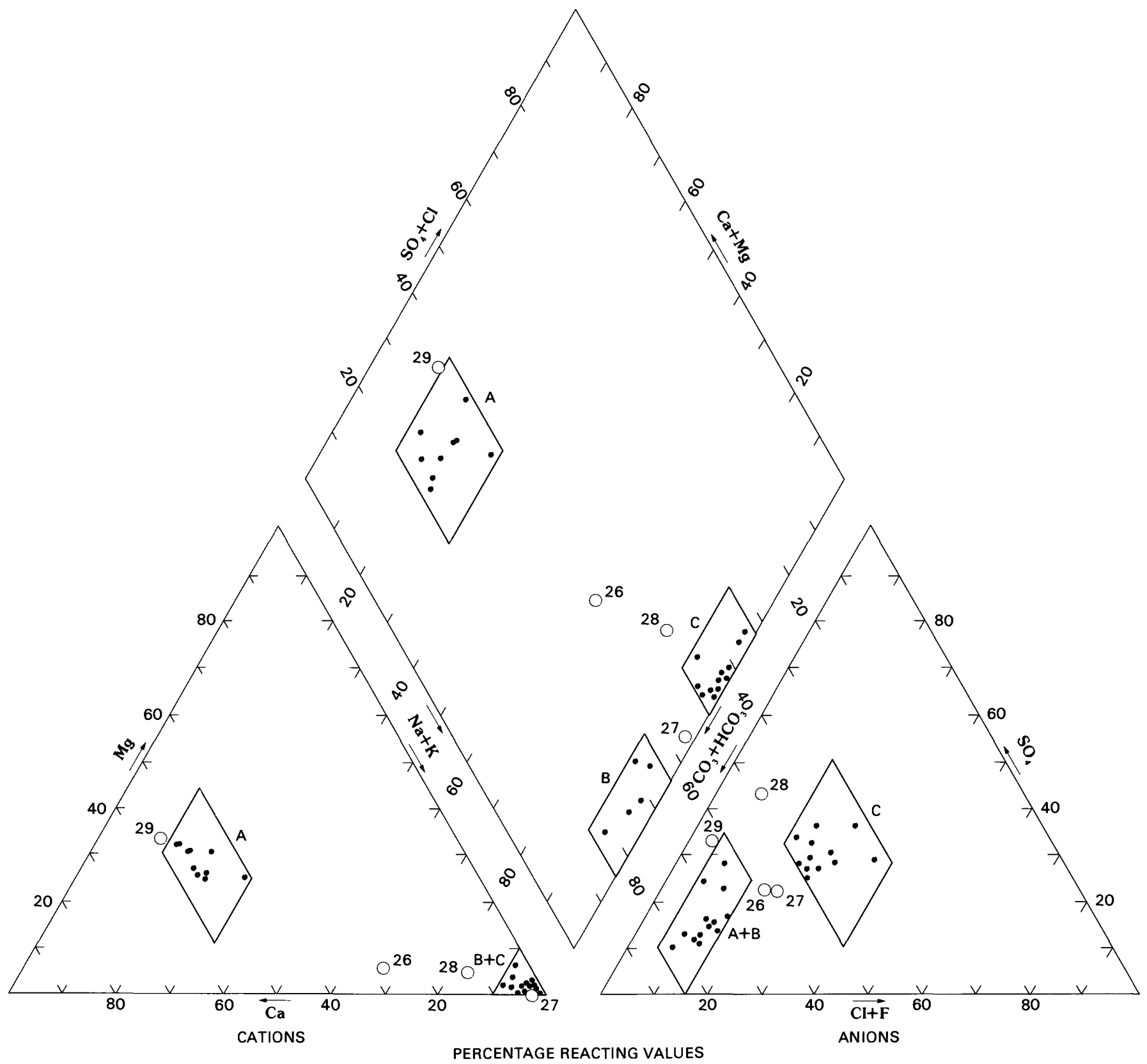

EXPLANATION

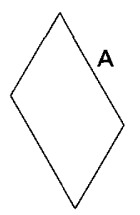

FIELD IN WHICH PERCENTAGES OF MAJOR ANIONS AND

CATIONS ARE SIMILAR-

Sources of samples are:

Field A, Cool local ground water; dissolved-solids

concentrations less than 400 milligrams per liter

Field B, Warmed local ground water and dilute thermal water; dissolved-solids concentrations less than 400 milligrams per liter

Field C, Thermal water; dissolved-solids concentrations greater than 700 milligrams per liter

$0^{29}$ IDENTIFICATION NUMBER OF ANALYSIS OUTSIDE FIELD

BOUNDARY (TABLE 3)

- ANALYSIS INSIDE FIELD BOUNDARY

FIGURE 18.-Percentage composition of water samples from wells, test holes, and springs. 
from flowing sources having larger concentrations of the same constituents. Upwelling thermal water similar to the samples included in field $C$ appears to be the main source of the major ions other than calcium and magnesium in the valley fill.

Analyses 20 to 25 represent the hot flowing sources and are the most likely to describe conditions in the deep reservoir. The relatively high hydraulic head tends to exclude local ground water from the conduits. These samples are less subject to contamination by residual drilling fluids or to chemical disequilibrium caused by airlift or pumping than are the samples from nonflowing sources.

Dissolution of quartz $\left(\mathrm{SiO}_{2}\right)$ and relatively insoluble sodium-bearing silicates and accessory minerals in the metamorphic rock by hot circulating water containing dissolved carbon dioxide $\left(\mathrm{CO}_{2}\right)$ is the most likely process by which the dissolved solids enter the thermal water. Quartz and degradable silicates that might release silica and component ions by solution or hydrolysis are abundant in the metamorphic rock and overlying valley fill. Detrital grains of the same minerals, as well as lithic grains, various forms of cryptocrystalline or amorphous silica, shards of volcanic glass, and clay minerals, are plentiful in the heterogeneous valley fill, but the specific mineralogy of those sediments is not well known.

Meteoric water normally contains carbon dioxide from the atmosphere and the soil. Carbon dioxide can also be formed by thermal decomposition of hydrocarbons. Although its solubility in water varies inversely with temperature, carbon dioxide is retained in solution where the hydrostatic pressure exceeds the partial pressure of carbon dioxide. There, it can decrease the $\mathrm{pH}$ of the water and react with minerals in the rock to form soluble bicarbonates and clay minerals with the release of silica. Depending on the composition of the silicates, accessory minerals, and inclusions, other major ions and silica, as well as trace constituents such as boron and lithium, would be released concurrently.

The simplified equations

$$
\begin{gathered}
\mathrm{CO}_{2}+\mathrm{H}_{2} \mathrm{O} \rightleftarrows \mathrm{H}^{+}+\mathrm{HCO}_{3}^{-} \\
\text {and } \\
2 \mathrm{NaAlSi}_{3} \mathrm{O}_{8}+2 \mathrm{H}^{+}+9 \mathrm{H}_{2} \mathrm{O} \rightleftarrows \mathrm{Al}_{2} \mathrm{Si}_{2} \mathrm{O}_{5}(\mathrm{OH})_{4} \\
+4 \mathrm{H}_{4} \mathrm{SiO}_{4}+2 \mathrm{Na}^{+}
\end{gathered}
$$

might represent the reaction of water containing carbon dioxide with sodium feldspar to form the clay mineral kaolinite and a sodium bicarbonate water containing dissolved silica.

In the presence of abundant aqueous $\mathrm{Ca}^{2+}$ or $\mathrm{Mg}^{2+}$, montmorillonite, which readily participates in ionexchange reactions, might be formed. Equation 9 and acid reactions similar to equation 10 are reversible.

Analyses 26 to 29 plot outside the field boundaries of figure 18. A characteristic of the trilinear diagram is that mixtures theoretically plot along a line connecting the plots of the end members. Thus, sample 26 from the Yenny well near the southern boundary of the welldefined thermal anomaly (figs. 11 and 12) appears to be a mixture of the cool and thermal water included in fields A and C, respectively. Similarly, sample 27 from test hole TX-6 near the western edge of the thermal anomaly might be a mixture of the sodium-enriched water of fields $B$ and $C$.

Analyses of samples 28 and 29, collected from test hole TX-10 east of the Madison River (fig. 2), plot near fields $C$ and $A$, respectively. The concentrations of chloride, fluoride, and silica are among the smallest of all the samples. Sample 28, from a depth of about $226 \mathrm{~m}$, is a dilute sodium mixed-anion water. The analysis might characterize deep water in the argillaceous valley fill outside the local hydrothermal anomaly, but the anomalously small concentrations reported for dissolved solids and silica might reflect contamination with drilling fluid. Sample 29, from a depth of $33.5 \mathrm{~m}$, is a dilute calcium bicarbonate water suitable for domestic supply.

The general increase in the concentrations of dissolved solids with temperature and depth (table 3) indicates that many of the samples included in fields $B$ and $C$ might be simple mixtures of the flowing thermal waters included in field $C$ and the shallow cool ground water included in field $A$. However, the chloride concentrations and the ion distribution indicate that simple mixing is inadequate to produce most of the observed differences.

Soluble mineral sources of appreciable concentrations of chloride at the temperatures measured in the valley fill are unknown, and chloride ions are not expected to react to a significant extent with other ions in the water or minerals in the local ground-water environment. Therefore, simple mixtures of the waters in fields $A$ and $C$ should contain intermediate concentrations of chloride. On this basis, samples 14, 16, and 26 from the Griffin, Cyprus No. 1, and Yenny domestic wells, respectively, might be appreciable mixtures of the deep-seated thermal water and cool ground water. During pumping, shallow ground water might have entered these wells above the top of the slotted part of the casing.

Despite intermediate concentrations of sodium and fluoride, the relatively small concentrations of chloride, calcium, and magnesium indicate that samples included in field $B$ are not simple mixtures of the cool ground water included in field $A$ and the flowing thermal water 
included in field C. Instead, the concentrations indicate that water in field $B$ results from relative enrichment of the cool ground water included in field $A$ with sodium, at the expense of calcium and magnesium. The significantly larger concentrations of sodium and fluoride with respect to chloride in the warmer water included in field $B$, as opposed to field $A$, indicate supplementary sources of these constituents in the valley fill. These sources might be sodium ion that was adsorbed on clay particles, and fluorite $\left(\mathrm{CaF}_{2}\right)$ deposited from upwelling thermal water that cooled as it permeated the valley fill.

The chemical processes that probably result in the chemical differences in field- $B$ water, as opposed to fieldA water, include cation exchange, precipitation of calcium carbonate as a result of conductive heating or limited mixing with hot waters, and formation of montmorillonite clay. Cation exchange of calcium or magnesium in the cool waters of field $A$ for sodium adsorbed on the abundant clay minerals in the valley fill and dissolution of fluorite could augment the concentrations of sodium and fluoride while they decrease the concentrations of calcium and magnesium without increasing the concentration of chloride. The governing reversible reaction could be

$\left(\mathrm{Ca}^{2+}\right.$ or $\left.\mathrm{Mg}^{2+}\right)+2 \mathrm{Na}$-clay $\rightleftarrows(\mathrm{Ca}$ or $\mathrm{Mg})-$ clay $+2 \mathrm{Na}^{+}(11)$

Precipitation of calcium carbonate might also decrease the calcium concentration. The solubility of calcium- and magnesium-bearing carbonates is governed largely by the content of dissolved carbon dioxide. The solubility of carbon dioxide in water decreases with increasing temperature. When carbon dioxide gas is released from calcium-bicarbonate-enriched water as a result of heating, or from the ascending thermal water as a result of the decrease in hydrostatic pressure, the $\mathrm{pH}$ increases, and calcium carbonate $\left(\mathrm{CaCO}_{3}\right)$ can precipitate as aragonite or calcite. Simplified equations representing the reactions are

$$
\begin{gathered}
\mathrm{HCO}_{3}^{-} \rightleftarrows \mathrm{CO}_{2(\mathrm{~g})}+\mathrm{OH}^{-} \\
\text {and } \\
\mathrm{OH}^{-}+\mathrm{HCO}_{3}{ }^{-}+\mathrm{Ca}^{2+} \rightleftarrows \mathrm{CaCO}_{3(\mathrm{c})}+\mathrm{H}_{2} \mathrm{O}
\end{gathered}
$$

where (g) denotes gas, and (c) denotes a crystalline solid.

The reactions are reversible. As written, the reactions would proceed to the right with decreasing pressure or increasing temperature. Precipitation of calcium carbonate as aragonite or calcite would leave the waters relatively enriched with respect to sodium. The relatively small concentration of calcium in the thermal water probably is largely the result of these reactions.
The precipitation process probably does not apply to magnesium because carbonate minerals containing magnesium do not readily precipitate from solution. However, some coprecipitation of magnesium in calcite may occur.

The computer programs WATEQF (Plummer and others, 1976) and SOLMNEQ (Kharaka and Barnes, 1973) were used to determine the theoretical reaction state of the sampled water, that is, whether common minerals would tend to dissolve or precipitate in the samples at the measured $\mathrm{pH}$ and subsurface temperature. Measurements of $\mathrm{pH}$ at the surface probably preceded most outgassing of carbon dioxide from the samples. As used here, the sample is undersaturated with respect to a mineral if the mineral dissolves in the water, in equilibrium if the rates of dissolution and precipitation theoretically are equal, and supersaturated if the mineral is insoluble or precipitates.

According to WATEQF, the samples of cool water in field $A$ at the sampling temperature were near equilibrium with the minerals aragonite and calcite and undersaturated with respect to the more soluble magnesite $\left(\mathrm{MgCO}_{3}\right)$ or dolomite $\left(\mathrm{CaMg}\left(\mathrm{CO}_{3}\right)_{2}\right)$ despite relatively large concentrations of magnesium. Theoretically, loss of carbon dioxide as a result of conductive heating would cause precipitation of calcium carbonate. The measured temperature of all the samples exceeded the mean annual air temperature of $6.8^{\circ} \mathrm{C}$. Slight warming of cool ground water during migration into the area could have caused precipitation of the calcium carbonates and the resulting equilibrium. With subsequent cooling, the water could have become undersaturated. Calcareous zones in the valley fill may constitute evidence of the reactions. Deposition of calcium carbonate near the boundaries between the ascending hot water and the cool ground water would tend to inhibit mixing in the valley fill by decreasing the permeability of the aquifer.

In field $\mathrm{B}$, only the samples from the flowing test holes TX-4 (sample 9) and TX-5 (sample 12) were undersaturated with respect to calcium carbonate, perhaps as a result of dissolved carbon dioxide in the artesian aquifers. Although cooler than sample 12, sample 12A, collected from test hole TX-5 after perforation of the casing above the well screen on December 4,1970 , was supersaturated with respect to both calcium and magnesium carbonates, probably reflecting the loss of carbon dioxide caused by a decrease of pressure at a shallower depth.

Samples of hot water from Ennis Hot Spring (sample 22), test hole TX-11 (sample 25), and the Thexton hot well (sample 23), all included in field $C$, were supersaturated with respect to aragonite and calcite. The samples from test hole TX-11, the Thexton well, and 
test hole TX-1 theoretically were supersaturated with respect to magnesite and dolomite as well, although hydration of the magnesium ion would probably inhibit precipitation of both. With the exception of the hot, supersaturated sample from test hole TX-1, all the samples from nonflowing sources in field $C$ theoretically were undersaturated with respect to the carbonates, mainly as a result of coohing.

At the sampling temperatures, all samples except those from the Griffin (sample 14) and Toth (sample 17) domestic wells were undersaturated with respect to fluorite $\left(\mathrm{CaF}_{2}\right)$. The upwelling thermal water appears to be the main source of fluoride $\left(\mathrm{F}^{-}\right)$in the study area. Theoretically, fluorite would precipitate from the sample from test hole TX-11 (sample 25) on cooling to about $20{ }^{\circ} \mathrm{C}$, lending credence to the preceding interpretation of the source of fluoride in the warmed water included in field B. Volcanic ash or fragments of pegrnatitic minerals observed in the valley fill are less probable sources.

Although affected by the varying depth of the sampled intervals, the areal distribution of water types, represented by each of the fields in figure 19, generally confirms the lateral flow pattern shown on the waterlevel maps (figs. 16 and 17) and the temperature-related maps (figs. 11 and 12). The pattern is consistent with upwelling of field-C-type water into the valley fill with warming and limited mixing along the boundaries of a northeast-trending plume. The upgradient boundary between the laterally moving cool water and the ascending thermal water is well defined.

The concentrations of the ions, silica, and stable isotopes in the samples probably reflect deep circulation through rocks of varying lithology exposed in the adjacent mountain ranges. The deep subsurface geology is relatively undefined, but the analyses are assumed to represent the last equilibrium conditions for temperature-dependent water-rock reactions in either a deep-seated reservoir in the metamorphic rock or in aquifers in the overlying valley fill in or near the discharge area.

\section{CHEMICAL QUALITY IN RELATION TO USE}

The dissolved-solid concentrations in samples of thermal water included in field $C$ exceed $500 \mathrm{mg} / \mathrm{L}$, the recommended maximum for drinking water (U.S. Environmental Protection Agency, 1979). The water is generally unsuitable for public water supplies or irrigation because of the large percentage of sodium (more than 90 percent of the cations) and the large concentrations of fluoride $(6.8$ to $20 \mathrm{mg} / \mathrm{L}$ ) and boron $(380$ to $740 \mu \mathrm{g} / \mathrm{L})$. Concentrations of fluoride in all samples included in field $C$ and in three samples in field B exceed $2.4 \mathrm{mg} / \mathrm{L}$, the maximum concentration established by the U.S. Environmental Protection Agency $(1977$, p. 5) for public water supplies.

The gross alpha and gross beta levels of radioactivity are less than the maximum contaminant levels specified by the U.S. Environmental Protection Agency (1977). However, radon would have been lost during sample preparation for gross alpha or beta analysis. The presence of helium and the high radioactivity of the crystalline aquifer warrant analysis for radon if the water is to be used for space heating.

\section{GEOTHERMOMETRY}

The silica geothermometers (Fournier, 1981; Fournier and Rowe, 1966), the Na-K-Ca (cation) geothermometer (Fournier and Truesdell, 1973) modified by the addition of a magnesium correction where applicable (Fournier and Potter, 1978), and the sulfate-oxygen-isotope geothermometer (McKenzie and Truesdell, 1977) were used in conjunction with the computer program SOLMNEQ to estimate minimum equilibrium temperatures for the water samples collected from the springs and wells. Equilibrium temperatures estimated from the cation and silica geothermometers and measured temperatures in the sampled zones are listed in table 3.

The analyses are assumed to represent the last equilibrium conditions for temperature- and pressuredependent water-rock reactions in the subsurface. Natural conditions that would invalidate estimates of deep-reservoir temperatures from the chemical geothermometers include depletion of the supply of reactants in the reservoir, reaction of the thermal water with minerals in the rock or valley fill, precipitation of silica or other minerals in the conduits during ascent to the surface, or mixing with nonthermal water. One or more of these conditions probably affect all samples from the valley fill. Their recognition can provide useful information about the hydrothermal system.

The silica geothermometers are based on the increasing solubility of the silica polymorphs with higher temperatures. The concentration of dissolved silica ranged from about $30 \mathrm{mg} / \mathrm{L}$ at a temperature of about $12^{\circ} \mathrm{C}$ in the cool, local ground water to $160 \mathrm{mg} / \mathrm{L}$ at about $94^{\circ} \mathrm{C}$ in test hole TX-11. The silica probably was derived principally from dissolution of quartz, chalcedony, and volcanic glass as well as by release of silica from silicate minerals by reactions similar to that of equation 10. Dilution would result in estimated temperatures that were too low.

The cation geothermometers depend mainly on cation ratios; therefore, they are less sensitive to dilution than 
the silica geothermometers. Most of the temperatures estimated from the $\mathrm{Na}-\mathrm{K}-\mathrm{Ca}$ geothermometer for analyses included in fields $B$ and $C$ are higher than temperatures estimated from the silica geothermometers (table 3). For some samples, the differences may reflect precipitation of calcium carbonate or ion exchange. The loss of aqueous $\mathrm{Ca}^{2+}$ will generally result in $\mathrm{Na}-\mathrm{K}-\mathrm{Ca}$ temperatures that are too high (Fournier, 1981, p. 119).

The smaller differences between the Na-K-Ca temperatures and the temperatures estimated for quartz, as opposed to the more soluble silica polymorphs such as chalcedony, might indicate that quartz controls the silica concentrations in samples of the

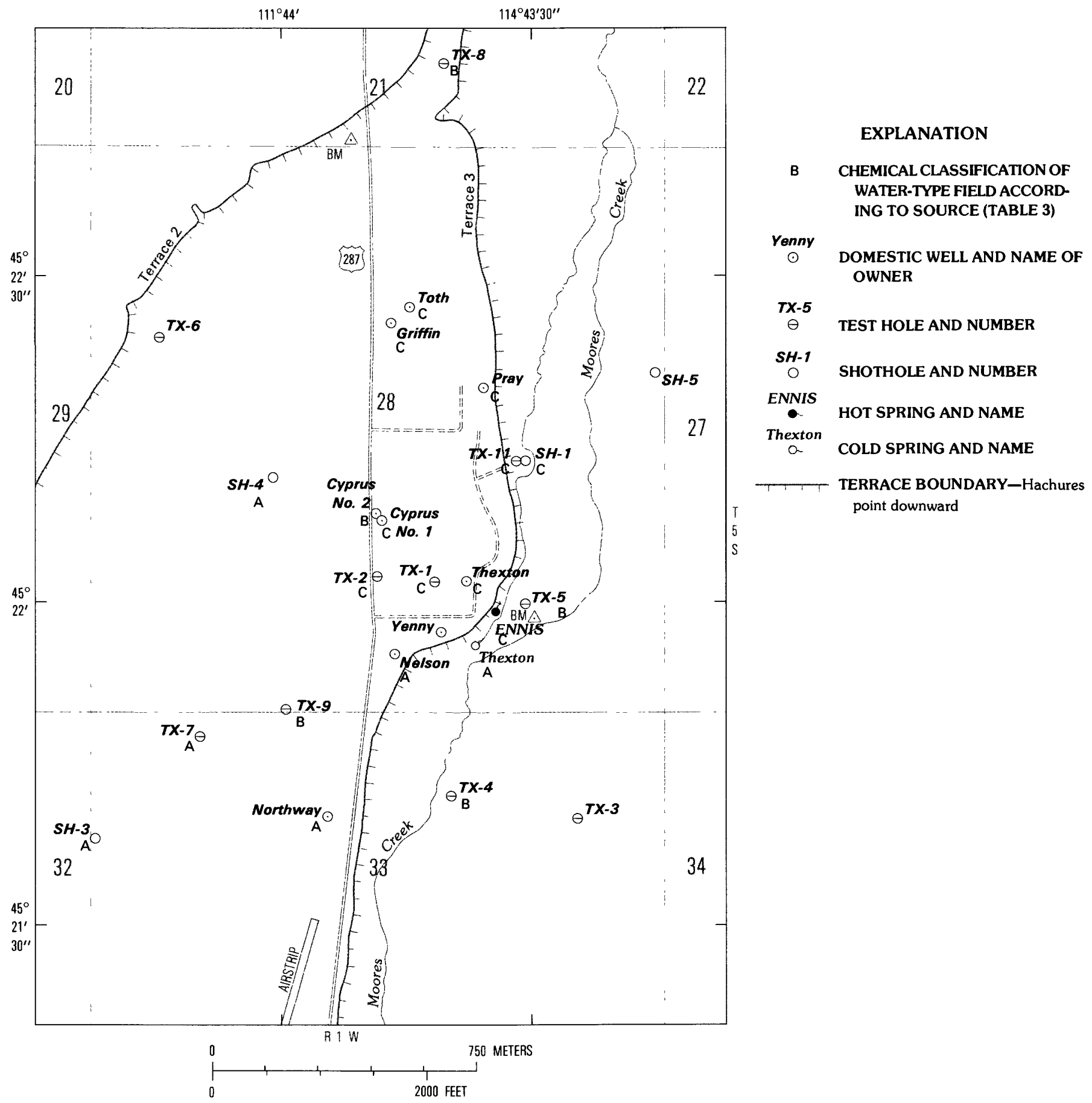

FIGURE 19.-Distribution of water-type fields in samples from wells, test holes, shotholes, and Ennis Hot Spring. 
flowing hot water. More soluble polymorphs might control the concentration of silica in cooler water. For example, all samples included in field $A$ are near equilibrium with amorphous silica, probably in the form of volcanic glass. Dissolution of quartz would account for less than $10 \mathrm{mg} / \mathrm{L}$ of the more than $30 \mathrm{mg} / \mathrm{L}$ of dissolved silica in the samples included in field $A$, although measured temperatures higher than the mean annual temperature $\left(6.8{ }^{\circ} \mathrm{C}\right)$ indicate conductive heating.

The temperatures estimated from the quartz geothermometers are higher than the measured temperatures at sampling depth for all samples, indicating that the water is supersaturated with respect to quartz. All samples except those from the nonflowing test holes TX-1 and TX-2 (analyses 19 and 15 in field C) are supersaturated with respect to the more soluble chalcedony as well.

All samples of the warmer water included in fields B and $C$ were undersaturated with respect to amorphous silica at the sampling temperatures. The aquifers might be deficient in amorphous silica at the sampled depth, perhaps as a result of leaching by warmer waters or the recrystallization of quartz.

Muffler (1979) suggested that quartz controls silica concentrations at temperatures greater than $180^{\circ} \mathrm{C}$ and in granitic rocks at temperatures as low as $90{ }^{\circ} \mathrm{C}$. Arnórsson (1975) concluded that the silica concentrations of hot springs, associated with low-temperature basaltic reservoirs in Iceland, are controlled by the solubility of chalcedony if the reservoir temperature is less than $110{ }^{\circ} \mathrm{C}$, by quartz and chalcedony in the temperature range 110 to $180{ }^{\circ} \mathrm{C}$, and by quartz at temperatures greater than $180{ }^{\circ} \mathrm{C}$. According to Fournier (1981), the quartz geothermometer works best where subsurface temperatures exceed about $150{ }^{\circ} \mathrm{C}$, which is about the temperature estimated for the flowing water in field $\mathrm{C}$.

Samples 21 through 25 of thermal water from flowing sources (table 3) are most likely to represent deepreservoir conditions. The rest of the samples appear to have reached at least partial equilibrium with the cooler, shallow subsurface environment and are more subject to dilution or chemical reactions with the valley fill.

Test hole TX-11 is cased and grouted through the valley fill, but water from the basal valley fill might enter the well through the uppermost perforations in the casing. Sample 24 may be contaminated with drilling fluid. Sample 25, collected from test hole TX-11 after a long period of flow, is probably most representative of water in the deep geothermal reservoir.

For sample 25, the similar estimated temperatures of $166{ }^{\circ} \mathrm{C}$ for the cation geothermometer and $165^{\circ} \mathrm{C}$ for the quartz geothermometer indicate lack of dilution, chemical reaction, or contamination after the water achieved equilibrium at depth. The chloride concentration $(120 \mathrm{mg} / \mathrm{L})$ is somewhat less than the minimum of about $150 \mathrm{mg} / \mathrm{L}$ normally associated with water that has exceeded $150{ }^{\circ} \mathrm{C}$ (White, 1973, p. 81) but is equal to or larger than concentrations in other samples from the study area. If the thermal gradient of $46{ }^{\circ} \mathrm{C} / \mathrm{km}$ (table 2) in the interval from 152.4 to $182.9 \mathrm{~m}$ persists, the estimated temperatures would be attained in the crystalline aquifer at a depth of about $1.7 \mathrm{~km}$ below the land surface.

Estimated equilibrium temperatures for sample 22 from Ennis Hot Spring are $159{ }^{\circ} \mathrm{C}$ for the cation geothermometer and $137{ }^{\circ} \mathrm{C}$ for the quartz geothermometer. The significantly smaller concentrations of silica in samples from the hot spring and other flowing sources included in field $\mathrm{C}$, as opposed to samples from test hole TX-11, indicate dilution with shallow ground water, precipitation of silica as a result of conductive cooling, or reactions of silica with clay minerals during ascent of the water through the $140 \mathrm{~m}$ of valley fill between the sampled zones. The similar concentrations of chloride and fluoride in the samples indicate that dilution is not the principal cause of the differences.

Precipitation of quartz, once dissolved, in the conduits at temperatures less than $180^{\circ} \mathrm{C}$ is relatively slow compared with the discharge rate of most hot springs (White and others, 1971). However, with cooling, amorphous silica can precipitate from stagnant water in the aquifer and eventually recrystallize as quartz. The major differences in the chemistry of the sample from test hole TX-11 and samples 20 through 23 from the other hot flowing sources probably represent precipitation of silica from ascending thermal waters during conductive cooling in natural conduits older and more tortuous than the well bore in test hole TX-11. The indurated clay or silt, which appears to form a confining layer near the base of the valley fill in test hole TX-11 (fig. 7), may be the principal site of silica deposition, particularly where it is breached by faulting.

The samples from test holes TX-1 and TX-2 are undersaturated with respect to chalcedony, and the (hot) sample from test hole TX-1 is nearly in equilibrium with quartz. The silica concentrations in samples from test holes TX-1 and TX-2 are much less than for the flowing sources, but the large chloride concentrations and the high temperature in the samples from test hole TX-1 do not indicate significant dilution with cool ground water. The equilibrium temperatures (140 to $157^{\circ} \mathrm{C}$ ) estimated from the cation geothermometer for the samples from the two test holes are within the range of the equilibrium temperatures estimated from the cation geothermometers for the flowing sources. However, the corresponding temperatures $\left(97\right.$ to $98{ }^{\circ} \mathrm{C}$ ) 
estimated from the quartz geothermometer are nearly equal to the measured temperature of $94{ }^{\circ} \mathrm{C}$ near the base of the valley fill in test hole TX-11. If the correspondence is more than coincidental, the similar temperatures and the relatively small silica concentrations may signify equilibration of the water with quartz at the ambient temperature measured near the base of the valley fill.

The sulfate-water-isotope geothermometer for the sample collected from Ennis Hot Spring in April 1976 indicated an equilibrium temperature of only $92^{\circ} \mathrm{C}$, far less than the temperatures of 135 to $151^{\circ} \mathrm{C}$ estimated from the quartz and cation geothermometers (R.H. Mariner, U.S. Geological Survey, written commun., 1978; Brook and others, 1979 , p. 74). The estimated temperature is near the temperature of $94{ }^{\circ} \mathrm{C}$ measured in test hole TX-11 at a depth of $158.5 \mathrm{~m}$ in an interval in which cores and cuttings of the fractured gneiss contained abundant pyrite. Formation of sulfate by oxidation of pyrite near the ambient temperature close to the base of the valley fill might account for the relatively low equilibrium temperature estimated from the sulfatewater geothermometer. Additional analyses of the water and rock for sulfide, sulfate, and stable isotopes would be needed to test the hypothesis.

The sulfate concentrations (in the range 210 to $220 \mathrm{mg} / \mathrm{L}$ ) in samples from Ennis Hot Spring are only slightly less than in samples from test hole TX-11 (in the range 210 to $270 \mathrm{mg} / \mathrm{L}$ ), indicating little if any dilution that would decrease the estimated temperature. All samples theoretically were undersaturated with respect to anhydrite $\left(\mathrm{CaSO}_{4}\right)$ or gypsum $\left(\mathrm{CaSO}_{4} \cdot \mathrm{H}_{2} \mathrm{O}\right)$ and supersaturated with respect to pyrite $\left(\mathrm{FeS}_{2}\right)$.

Relatively large concentrations of dissolved iron (160 to $200 \mu \mathrm{g} / \mathrm{L}$ ) in samples from test hole TX-11 support a pyrite source but indicate a locally reducing environment. Despite the absence of appreciable hydrogen sulfide in gas samples from test hole TX-11 (Leonard and Wood, 1980b, p. 13) or of reliable analyses for dissolved sulfide, a distinct odor of hydrogen sulfide emanated from the flowing water. Therefore, the sulfate probably was not formed by local oxidation of pyrite. The much smaller (10 to $20 \mu \mathrm{g} / \mathrm{L}$ ) concentration of dissolved iron in samples from the hot spring and other wells and the extremely ferruginous layers penetrated during drilling probably result from precipitation of iron compounds in diffuse conduits in the valley fill.

The combined geochemical data appear to support a model in which meteoric water heated by deep circulation to temperatures of at least $166{ }^{\circ} \mathrm{C}$ achieved equilibrium with quartz and sodium-rich silicates in crystalline rock at depth. After rapid ascent through fractures associated with faults in the crystalline rock, the thermal water spread laterally below a confining layer near the base of the valley fill where it achieved partial equilibrium with the minerals in the aquifer at a temperature of between 90 and $100{ }^{\circ} \mathrm{C}$.

Part of the sodium-enriched thermal water ascended tortuous conduits in the heterogeneous valley fill overlying breaches in the confining layer to spread laterally through discontinuous permeable layers or to emerge at Ennis Hot Spring. Appreciable mixing of cool and thermal water seemed to be associated only with pumping. Natural mixing was inhibited by the relatively high hydraulic head of the hot flowing water and the precipitation of silica, calcium carbonate, and iron compounds in the conduits. Convective circulation of thermal water in the crystalline rock was probably the main source of the predominantly conductive heat flow that warmed the shallow ground water over a wide area around the hot spring. Ion exchange and precipitation of calcium carbonate increased the relative and absolute concentrations of sodium in the warmed water.

\section{CONCEPTUAL MODELS OF THE HYDROTHERMAL SYSTEM}

The combined data collected near Ennis indicate that thermal water of meteoric origin rises along fractures associated with deep-seated faults in the crystalline bedrock west of the Madison River and spreads locally into the valley fill where a basal confining layer is breached. The nature of the remainder of the system is conjectural and subject to multiple interpretations based on meager data.

The nature of the associated faults is unknown. The buried scarps that converge north of the hot spring might be the erosional traces of faults-a normal fault parallel to and contemporaneous with, but of far smaller displacement than, the Madison fault and a younger transverse fault parallel to the Bismark-Gardiner fault zone (fig. 2). The faults also might be westerly dipping thrust and complementary tear faults similar to those which displace crystalline rock along the west flank of the Madison Range. Fracture zones associated with thrust faults could provide avenues for lateral migration of thermal waters under artesian head. Finally, if the north-northeast scarp is the trace of one of a series of step faults or of a strike-slip fault parallel to those mapped in the Madison Range and to foliation in the gneiss exposed west of the spring, the deep circulation might be confined to a broad band of associated shear fractures. All these faults may intersect a thrust fault at depth.

An east-west section through the Ennis area resembles the shallow axial part of a model by Blackwell and Chapman (1977) of a hot spring along a range-bounding 
fault in a basin-and-range setting (fig. 13). In the model, the water rising along the fault was heated to a temperature of about $100^{\circ} \mathrm{C}$ by normal conductive heat flow at a depth of $1.5 \mathrm{~km}$ near the base of the valley fill. Chadwick and Leonard (1979) postulated similar models for other springs along range-bounding faults in Montana. There, the paleovalleys are portrayed as grabens. At Ennis, the regional gravity data portray a half graben in which the valley fill along and east of the fault beneath the hot spring is much thinner (thickness about $0.23 \mathrm{~km}$ ) than in the basin-and-range model and thickens progressively to the east to about $1.2 \mathrm{~km}$ near the Madison fault (fig. 20).

Westerly migration of thermal waters from the deepest part of the asymmetric basin, near the Madison fault, might be inferred by analogy with the conceptual models. Mountain streams crossing the Madison fault zone, or water in the overlying alluvial fans, could provide adequate recharge with sufficient hydraulic head to promote deep circulation along the associated fracture zones. However, with a "normal" temperature gradient of about $60^{\circ} \mathrm{C} / \mathrm{km}$, the temperature in valley fill at a depth of $1.2 \mathrm{~km}$ near the Madison fault would only be about $80^{\circ} \mathrm{C}$-even lower than the measured temperature of the hot spring. Although the extrapolated temperature gradient in test hole TX-10 indicates that the temperature at a depth of $1.2 \mathrm{~km}$ in the valley fill would be about $110^{\circ} \mathrm{C}$, the water temperature would probably decrease during westward and upward migration along the sloping bedrock surface.

The equilibrium temperature of $166{ }^{\circ} \mathrm{C}$ estimated from the cation geothermometer for a sample from test hole TX-11 theoretically would be attained at a depth of about $1.8 \mathrm{~km}$ in test hole TX-10, near the depth of $1.7 \mathrm{~km}$ estimated from the thermal gradient in test hole $\mathrm{TX}-11$. If the geophysical portrayal of the geologic framework is valid, both depths are below the base of the valley fill, indicating that westward migration of hot water from the Madison fault to the hot spring would be confined chiefly to the crystalline rock. The western extensions of the thrust faults mapped along the flank of the Madison Range probably underlie the study area at a depth greater than $2 \mathrm{~km}$. The water could migrate laterally under artesian head through associated fracture zones while it absorbs heat in a wide area, then rise rapidly along the normal faults near the hot spring with minimal decrease in temperature.

Thermal alteration along transverse faults or fracture zones in the bedrock might cause the northwesttrending, minimal-resistivity anomalies indicated by the deep AMT soundings in the 7.5- $\mathrm{Hz}$ band. Transverse faults or fracture zones could provide deep-seated conduits in the crystalline rock along which thermal water could move laterally without an appreciable decrease

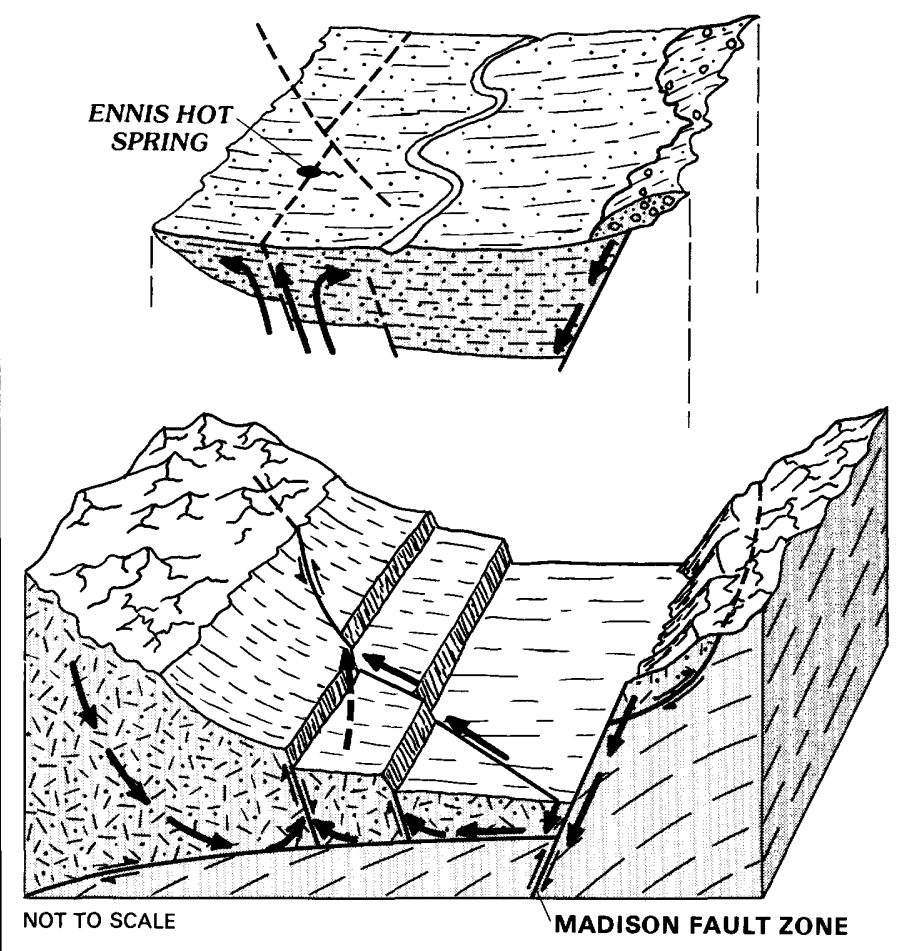

EXPLANATION

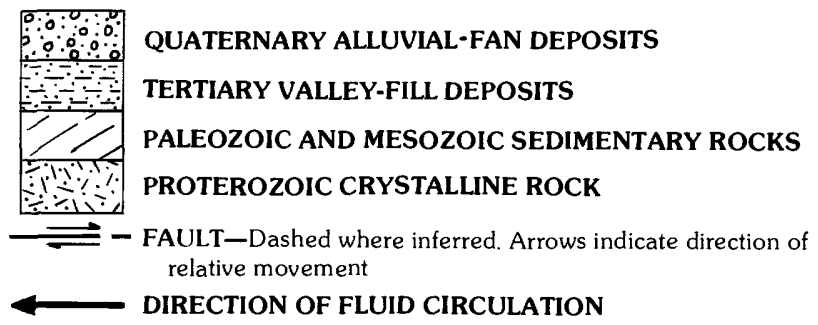

FIGURE 20.-Conceptual model of the hydrothermal system that includes Ennis Hot Spring.

in temperature, or more probably, along which water could leak from fracture zones associated with underlying thrust faults. The half-graben model shown in figure 20 appears to be the most consistent with the data.

Ground water in the Madison River valley upstream from the study area is an alternative source of recharge to the system. The leakage zone of thermal water appears to extend for at least $6 \mathrm{~km}$ north of the hot spring. The hot spring might be part of a sheet of fluid circulation along which only a small part discharges at the surface. A fracture zone associated with a series of north-trending step faults or a major strike-slip fault might be sufficiently extensive to include both recharge and discharge areas. Supporting data would be difficult and costly to obtain.

If broad areas of fractured crystalline rock exposed in the adjacent Tobacco Root Mountains were the recharge area for the system, the conceptual model 
could be less complex than for a recharge area along the Madison fault. However, as a result of the large thermal conductivity of the crystalline rock, the model would indicate circulation to depths of more than $5 \mathrm{~km}$ if the minimum equilibrium temperature estimated from the chemical geothermometers and the "normal" gradient of about $30{ }^{\circ} \mathrm{C} / \mathrm{km}$ for the crystalline rock were valid.

The local structure and configuration of the concealed bedrock at Ennis Hot Spring appear to be somewhat similar to those exposed at Potosi Hot Springs, about $25 \mathrm{~km}$ to the northwest. There, the entire hydrothermal system appears to be in crystalline rock, remote from thick deposits of valley fill. Potosi Hot Springs are located in the Tobacco Root Mountains at the intersection of the northwest-trending Bismark-Gardiner fault zone (fig. 1) and a local northeast-trending fracture zone (Galloway, 1977; Chadwick and Leonard, 1979). The thermal water issues from fractures in quartz monzonite for a distance of about $400 \mathrm{~m}$ along the east face of a north-trending erosional scarp. The maximum temperature of $51^{\circ} \mathrm{C}$ and the fluctuating lower temperatures at peripheral vents are probably the result of dilution with shallow water in the unconfined aquifer.

If buried and partly confined by valley fill, Potosi Hot Springs might closely resemble Ennis Hot Spring. The higher measured and estimated temperatures at Ennis might result largely from exclusion of dilutant ground water from the conduits by the overlying valley fill as well as from deeper circulation. By analogy, the major convective system at Ennis might be confined mainly to the fractured crystalline rock exposed in a broad recharge area in the Tobacco Root Mountains and penetrated by test holes in the discharge area west of the Madison River. Fracture zones associated with deep-seated thrust faults might provide avenues for lateral movement of the water. However, the large apparent resistivity values west of the river valley, as shown by the AMT surveys, do not support this hypothesis.

The ascending limb of the convective cell at Ennis seems to be confined principally to fractures in the crystalline bedrock. Because the spacing, extent, and width of the fractures vary greatly, quantitative definition of the extent or characteristics of the crystalline reservoir would require extensive drilling and testing. The hottest water in the valley fill in the Ennis area and at other hot springs in Montana is probably localized near the area of discharge from fracture zones associated with faults in the bedrock. The sustained yield of hot water from wells in the valley fill ultimately depends on the unknown quantity of recharge from the crystalline aquifer.

\section{SUMMARY AND CONCLUSIONS}

Ennis Hot Spring issues from valley fill in the Madison River valley in southwestern Montana. The surface temperature of about $83^{\circ} \mathrm{C}$ is the hottest for natural springs in the State. The valley fill conceals structure in the underlying bedrock.

An erosional surface of high relief on fractured and faulted gneiss and schist of Proterozoic age extends under the hot spring from exposures at the base of the Tobacco Root Mountains about $2.5 \mathrm{~km}$ to the west. Similar rock is exposed in fault contact with valley fill of late Cenozoic age along the northwest-trending Bismark-Gardiner fault zone to the north and the seismically active Madison fault zone at the base of the Madison Range about $10 \mathrm{~km}$ east of the hot spring.

Exposed intrusive and extrusive igneous rock is probably too old to be a source of residual magmatic heat. Deep circulation of water is required to attain the temperature measured at the spring. Recent seismic activity probably maintains open conduits for deep circulation of meteoric and thermal waters in fracture zones along new or existing faults. Perennial streamflow in the Madison River valley and mean annual precipitation exceeding $1,000 \mathrm{~mm}$ in the surrounding highlands provide adequate potential recharge for the hydrothermal system.

Regional gravity data indicate that the bedrock surface slopes gently to the east from a depth of about $0.23 \mathrm{~km}$ under the hot spring to about $1.2 \mathrm{~km}$ near the Madison fault. The fault underlying the spring may be one of a sequence of step faults downthrown to the east.

Detailed gravity surveys probably portray a buried block of schist and gneiss (density about $2.6 \mathrm{~g} / \mathrm{cm}^{3}$ ). The block is probably bounded on the east and northeast by fault scarps that intersect north of the spring.

Results of intermediate-depth, seismic-refraction profiles generally confirm the configuration of the bedrock surface described by the gravity surveys. A northtrending fault, downthrown about $70 \mathrm{~m}$ to the east, evidently intersects a northwest-trending transverse fault, downthrown to the northeast, about $450 \mathrm{~m}$ north of the spring. The configuration of the velocity layers indicates horizontal stratification but confirms lateral discontinuity and vertical heterogeneity in the valley fill as well as relatively large relief on the bedrock surface. Shallow seismic profiles confirm the heterogeneity of the shallow valley fill. However, the profiles failed to define the bedrock surface.

Relatively small scalar resistivities measured during AMT soundings describe the occurrence of thermal water or rock alteration in an elliptical area of about 600 ha that includes the hot spring. A northerly extension of anomalously small resistivity described for the 
$27-\mathrm{Hz}$ band might represent leakage of thermal water along a series of faults or a fracture zone between the hot spring and Ennis Lake. Deeper northwest-trending anomalies portrayed by the $7.5-\mathrm{Hz}$ band probably describe intersecting transverse faults affecting the deeper bedrock.

Results of single E-field telluric profiles appear to describe a zone of alteration east of a north-trending fault near the hot spring. Complex subsurface structure and another fault may be present to the southwest.

Shallow direct-current resistivity soundings appear to be unduly affected by variation in the electrical conductivity of surficial materials. Northeast migration with depth of an elliptical area of small resistivity centered on the hot springs may indicate upwelling of thermal water from this direction.

Drillers' logs of existing wells in the valley fill indicate considerable lithologic variation, local artesian conditions, and generally northeast waterflow in the valley fill in the study area. Yields of 3.2 to $6.3 \mathrm{~L} / \mathrm{s}$ are common. Wells in the adjacent metamorphic rock generally yield less than $1.3 \mathrm{~L} / \mathrm{s}$ from isolated fracture zones. Reported yields of thermal water from domestic wells in the valley fill were as much as $2.5 \mathrm{~L} / \mathrm{s}$.

Data from wells, shotholes, and test holes drilled to depths between 15.2 and $267 \mathrm{~m}$ generally confirmed results of the surface geological and geophysical investigations. The valley fill mainly consists of poorly consolidated and commonly calcareous tuffaceous clay, silt, and argillaceous sand, all interbedded with lenticular layers of coarse sand and gravel. Test hole TX-11, which is $450 \mathrm{~m}$ north of the spring, penetrated fractured hornblende gneiss containing water with a temperature of about $94{ }^{\circ} \mathrm{C}$ near the intersection of fault scarps and at a depth of about $160 \mathrm{~m}$ predicted from seismic-refraction profiles.

Correlation of the lithologic and borehole geophysical logs generally confirmed gentle dips and minor displacements of discontinuous strata in the valley fill. A bed of well-consolidated silt and clay near the base of the valley fill may be an extensive confining layer. Anomalous natural-gamma response is attributed to radioactive crystalline rock and coarse-grained sediment derived therefrom.

Temperatures in 11 grouted test holes generally increased with depth, ranging from $6.2{ }^{\circ} \mathrm{C}$ near the water table in test hole TX-4 to $94.1{ }^{\circ} \mathrm{C}$ in fractured crystalline rock at a depth of $185.3 \mathrm{~m}$ in test hole TX-11. Temperature-depth profiles indicate heat flow by conduction, convection, and a combination of the two processes. The profiles for the lower part of most test holes consist of rectilinear segments corresponding to lithologic units of constant thermal conductivity. Temperature gradients in the valley fill range from -35 to about $300{ }^{\circ} \mathrm{C} / \mathrm{km}$.
Profiles and maps showing the lateral distribution of temperature in the valley fill appear to describe upwelling of hot water from the crystalline rock through a breached confining layer at the base of the valley fill. Lateral spreading in a northeast-trending plume extends throughout an area of at least 300 ha west of the Madison River.

Conductive heat flow in the valley fill exceeds maximum normal regional heat flow of $105 \mathrm{~mW} / \mathrm{m}^{2}$ in nearly all test holes west of the Madison River in which the temperature is less than $50{ }^{\circ} \mathrm{C}$. An abnormally large temperature gradient of $88{ }^{\circ} \mathrm{C} / \mathrm{km}$ in the lower part of test hole TX-10, east of the river, is attributed to the small thermal conductivity of saturated clay. Conductive heat flow appears to be about the regional norm; therefore, the well appears to be near or beyond the eastern boundary of the thermal anomaly. Small thermal gradients (less than $30^{\circ} \mathrm{C} / \mathrm{km}$ ) and subnormal heat flow indicate that wells in adjacent highlands are probably in a recharge zone.

Temperature and water-level measurements in 41 shallow (depth of $2 \mathrm{~m}$ ) test holes indicated near-surface discharge of thermal water north-northeast of the spring in an area unsuitable for heavy drilling equipment. The discharge of $1.2 \mathrm{~L} / \mathrm{s}$ measured at the hot spring probably represents a small percentage of the total discharge of thermal water.

Water levels in test holes and shotholes ranged from $12.3 \mathrm{~m}$ above the land surface to $8.8 \mathrm{~m}$ below the land surface. Five test holes and a shothole flowed at the surface. Hydraulic head in the valley fill west of the river generally increased with depth but decreased with depth in test hole TX-10, east of the river. The maximum hydraulic head was measured in test hole TX-11 from perforations in crystalline rock and basal valley fill.

The decrease in water density with increasing temperature significantly affects measured water levels in the hottest holes. Hydraulic gradients inferred from coldwater equivalent hydraulic heads adjusted to an arbitrary datum indicate lateral emplacement of thermal water from the crystalline bedrock in valley-fill aquifers that intersect a common conduit associated with a north-trending fault.

Pumping and flow tests of the fractured crystalline aquifer after the investigation confirmed hydraulic connection among a test hole, two wells, and the hot spring along the postulated north-northeast-trending fault zone. Maximum temperatures of $92{ }^{\circ} \mathrm{C}$ at a depth of $150 \mathrm{~m}$ and $97^{\circ} \mathrm{C}$ at a depth of $335 \mathrm{~m}$ were reportedly measured in fracture zones in the crystalline rock.

The relatively large $(120 \mathrm{mg} / \mathrm{L})$ concentration of chloride indicates that Ennis Hot Spring is part of a convective hot-water hydrothermal system. Ratios of the stable isotopes of hydrogen and oxygen in the 
thermal waters denote a meteoric origin with relatively minor water-rock interaction.

Calcium and bicarbonate are the predominant ions in the diluted (less than $400 \mathrm{mg} / \mathrm{L}$ dissolved solids) local ground water; sodium and sulfate plus chloride characterize the relatively undiluted (more than $950 \mathrm{mg} / \mathrm{L}$ dissolved solids) thermal waters from flowing sources near the conduit. Sodium and bicarbonate characterize warmed waters and mixtures of the two, which are relatively enriched in sodium by precipitation of calcium carbonate and, perhaps, ion exchange. The distribution of water types generally confirms the flow pattern described by temperature and water-level maps. Large percentages of sodium and excessive concentrations of fluoride and boron generally make the thermal waters unsuitable for public water supplies or irrigation.

Minimum equilibrium temperatures of 166 and $165{ }^{\circ} \mathrm{C}$ were estimated using the cation and quartz geothermometers for a water sample from the crystalline-rock aquifer penetrated in test hole TX-11. Lower estimated temperatures for the hot spring and several hot wells are mainly the result of the limited mixing of temperature-controlled water-mineral reactions with cooler ground water.

The estimated temperatures for most of the thermal waters from nonflowing sources range from about 90 to $100{ }^{\circ} \mathrm{C}$ using the quartz geothermometer. The relatively small and uniform silica concentrations might signify long residence time and equilibration of water with quartz near the base of the valley-fill aquifer.

The sulfate-water-isotope geothermometer yielded an equilibrium temperature of only $92{ }^{\circ} \mathrm{C}$ for the hot spring. Formation of the sulfate by oxidation of pyrite in the crystalline rock at the ambient temperature measured near the base of the valley fill in test hole TX-11 could account for the relatively low estimated temperature.

Anomalously large concentrations of helium associated with the thermal waters probably originate from radioactive decay in the crystalline rock. The gross alpha and beta activities of the thermal waters are considerably less than maximum contaminant levels for public water supplies, but radon might be present. The source of hydrogen, found in abnormally large concentrations in gas samples from test hole $\mathrm{TX}-5$, is unknown.

The major hydrothermal system appears to be confined to fractured crystalline rock. Several conceptual models appear to be consistent with the data:

1. Water recharged in the Madison Range and along the Madison fault zone east of Ennis Hot Spring could migrate laterally, with additional heating from the axial part of the basin, through the crystalline rock along deep-seated fracture zones associated with thrust or transverse faults, before rising rapidly through vertical fractures in the vicinity of the spring. If the paleovalley were deeper and less symmetrical than the half graben portrayed by the regional gravity data, a classical basin-and-range graben model might apply.

2. A broad fracture or shear zone associated with a series of north-trending step faults, downthrown to the east, or a strike-slip fault may be sufficiently extensive to include both recharge and discharge areas along the west side of the Madison River valley.

3. The water may circulate along fracture systems in the crystalline rock exposed in a recharge area in the Tobacco Root Mountains to the west and penetrated by test holes in the study area.

The hottest water in the valley fill at Ennis and at most other hot springs in Montana probably is localized near the area of discharge from conduits in the crystalline aquifers. More meaningful evaluations of the volume and extent of the geothermal reservoir than have been presented in published assessments would require extensive drilling and testing.

\section{SELECTED REFERENCES}

Arnórsson, Stefán, 1975, Application of the silica geothermometer in low temperature hydrothermal areas in Iceland: American Journal of Science, v. 275, no. 7, p. 763-784.

Bankey, Viki, Paton, Jody, and Kleinkopf, M.D., 1980, Principal facts for gravity stations, Ennis geothermal area, Montana: U.S. Geological Survey Open-File Report 80-1084, 12 p.

Blackwell, D.D., and Chapman, D.S., 1977, Interpretation of geothermal gradient and heat flow data for Basin and Range geothermal systems: Geothermal Resources Council Transactions, v. 1, p. 19-20.

Blackwell, D.D., and Robertson, E.C., 1973, Thermal studies of the Boulder batholith and vicinity, Montana: Society of Economic Geologists Guidebook, Butte Field Conference, p. D1-D8.

Brook, C.A., Mariner, R.H., Mabey, D.R., Swanson, J.R., Guffanti, Marianne, and Muffler, L.J.P., 1979, Hydrothermal convection systems with reservoir temperatures $\geqslant 90^{\circ} \mathrm{C}$, in Muffler, L.J.P. ed., Assessment of geothermal resources of the United States-1978: U.S. Geological Survey Circular 790, p. 18-85.

Burfeind, W.J., 1967, A gravity investigation of the Tobacco Root Mountains, Jefferson basin, Boulder batholith, and adjacent areas of southwestern Montana: Bloomington, Indiana University Ph. D. thesis, $90 \mathrm{p}$.

Chadwick, R.A., 1970, Belts of eruptive centers in the AbsarokaGallatin volcanic province, Wyoming-Montana: Geological Society of America Bulletin, v. 81, no. 1, p. 267-273.

$1978 \mathrm{a}$, Geochronology of post-Eocene rhyolitic and basaltic volcanism in southwestern Montana: Isochron/West, no. 22, p. 25-28.

1978b, Geothermal reconnaissance of southwestern Montana: Final Report, prepared under U.S. Geological Survey grant Nos. 14-08-0001-G-238 and 334, 36 p.

Chadwick, R.A., and Leonard, R.B., 1979, Structural controls of 
hot-spring systems in southwestern Montana: U.S. Geological Survey Open-File Report 79-1333, 25 p.

Christopherson, K.R., Senterfit, R.M., Lewis, Vernon, and Dalati, Moutaz, 1979, Telluric profiles and location map for the Ennis Hot Spring area, Montana: U.S. Geological Survey Open-File Report 79-1671, 5 p.

Craig, Harmon, 1961, Standard for reporting concentrations of deuterium and oxygen-18 in natural waters: Science, v. 133, no. 3467, p. 1833-1834.

1963 , The isotope geochemistry of water and carbon in geothermal areas, in Tongiorgi, Exio, ed., Nuclear geology of geothermal areas, Spoleto: Pisa, Italy, Consiglio Nazionale della Ricerche, Laboratorio de Geologic Nucleare, p. 17-53.

Doering, W.P., and Friedman, Irving, 1980, Survey of helium in natural water wells and springs in southwest Montana and vicinity, Part II-July 1-December 31, 1979: U.S. Geological Survey Open-File Report 80-1254, $18 \mathrm{p}$.

Fournier, R.O., 1981, Application of water geochemistry to geothermal exploration and reservoir engineering, in Rybach, L., and Muffler, L.J.P., eds., Geothermal systems-Principles and case histories: New York, John Wiley, p. 109-143.

Fournier, R.O., and Potter, R.W., II, 1978, A magnesium correction to the $\mathrm{Na}-\mathrm{K}-\mathrm{Ca}$ chemical geothermometer: Geochimica et Cosmochimica Acta, v. 43, no. 10, p. 1543-1550.

Fournier, R.O., and Rowe, J.J., 1966, Estimation of underground temperatures from the silica content of water from hot springs and wet-steam wells: American Journal of Science, v. 264, no. 9 , p. 685-697.

Fournier, R.O., and Truesdell, A.H., 1973, An empirical Na-K-Ca geothermometer for natural waters: Geochimica et Cosmochimica Acta, v. 37, p. $1255-1275$.

1974 , Geochemical indicators of subsurface temperature, Part 2, Estimation of temperature and fraction of hot water mixed with cold water: U.S. Geological Survey Journal of Research, v. 2, no. 3, p. 263-270.

Fournier, R.O., White, D.E., and Truesdell, A.H., 1974, Geochemical indicators of subsurface temperature, Part 1, Basic assumptions: U.S. Geological Survey Journal of Research, v. 2, no. 3, p. 259-262.

Gabelman, J.W., 1976, Expectations from uranium exploration: American Association of Petroleum Geologists Bulletin, v. 60, no. 11, p. 1993-2004.

Galloway, M.J., 1977, Qualitative hydrologic model of thermal springs in fractured crystalline rock: Bozeman, Montana State University, M.S. thesis, 197 p.

Hodgman, C.D., Weast, R.C., Shankland, R.S., and Selley, S.M., eds., 1962, Handbook of chemistry and physics: Cleveland, Ohio, Chemical Rubber, $3513 \mathrm{p}$.

Hoover, D.B., and Long, C.L., 1976, Audio-magnetotelluric methods in reconnaissance geothermal exploration: Proceedings of the Second United Nations Symposium on the Development and Use of Geothermal Resources, May 20-29, 1975, San Francisco, Calif., v. 2, p. 1059-1064.

Johnson, M.V., and Omang, R.J., 1976, A method for estimating magnitude and frequency of floods in Montana: U.S. Geological Survey Open-File Report 75-650, 35 p.

Jorgensen, D.G., Gogel, A.J., and Signor, D.C., 1982, Determination of flow in aquifers containing variable density water: Groundwater Monitoring Review, v. 2, no. 2, p. 40-45.

Kazamarek, M.B., 1974, Geothermometry of selected Montana hot spring waters: Bozeman, Montana State University, M.S. thesis, $141 \mathrm{p}$.

Kharaka, Y.K., and Barnes, Ivan, 1973, SOLMNEQ: Solution-mineral equilibrium computations, with modifications by $\mathrm{H}$. C. Helgeson in 1980 and 1981: U.S. Geological Survey Computer Contribution, available from the National Technical Information Service, U.S.
Department of Commerce, Springfield, Va. 22151, Report PB-215899, 82 p.

Leonard, R.B., Brosten, T.M., and Midtlyng, N.A., 1978, Selected data from thermal-spring areas, southwestern Montana: U.S. Geological Survey Open-File Report 78-438, $71 \mathrm{p}$.

Leonard, R.B., and Janzer, V.J., 1978, Natural radioactivity in geothermal waters, Alhambra Hot Springs and nearby areas, Jefferson County, Montana: U.S. Geological Survey Journal of Research, v. 6 , no. 4 , p. $529-540$.

Leonard, R.B., and Wood, W.A., 1980a, Geothermal gradients in the Missoula and Bitterroot Valleys, west-central Montana: U.S. Geological Survey Water-Resources Investigations 80-89, 15 p. $1980 \mathrm{~b}$, Supplemental data from the Ennis and other thermalspring areas, southwestern Montana, 1978-80: U.S. Geological Survey Open-File Report 80-1182, 79 p.

Long, C.L., and Senterfit, R.M., 1979, Audio-magnetotelluric data log and station-location map for the Ennis Hot Spring area, Montana: U.S. Geological Survey Open-File Report 79-1308, 7 p.

Mariner, R.H., Presser, T.S., and Evans, W.C., 1976, Chemical characteristics of the major thermal springs of Montana: U.S. Geological Survey Open-File Report 76-480, $31 \mathrm{p}$.

McKenzie, W.F., and Truesdell, A.H., 1977, Geothermal reservoir temperatures estimated from the oxygen isotope compositions of dissolved sulfate and water from hot springs and shallow drill holes: Geothermics, v. 5, no. 1, p. 51-61.

Montagne, John, 1960, Geomorphic problems in the Madison Valley, Madison County, Montana-An introduction and synthesis: Billings, Mont., Billings Geological Society Guidebook, 11th Annual Field Conference, p. 165-169.

Muffler, L.J.P., ed., 1979, Assessment of geothermal resources of the United States-1978: U.S. Geological Survey Circular 790, 163 p.

Nathenson, Manuel, Guffanti, Marianne, Sass, J.H., and Monroe, R.J., 1983, Regional heat flow and temperature gradients, in Reed, M.J., Assessment of low-temperature geothermal resources of the United States-1982: U.S. Geological Survey Circular 892, p. 9-16.

Nehring, N.L., Mariner, R.H., White, L.D., Huebner, M.A., Roberts, E.D., Harmon, Karen, Bowen, P.A., and Tanner, Lane, 1979, Sulfate geothermometry of thermal waters in the western United States: U.S. Geological Survey Open-File Report 79-1135, 11 p.

Olmsted, F.H., 1977, Use of temperature surveys at a depth of 1 meter in geothermal exploration in Nevada: U.S. Geological Survey Professional Paper 1044-B, p. B1-B25.

Pardee, J.T., 1950, Late Cenozoic block faulting in western Montana: Geological Society of America Bulletin, v. 61, no. 4, p. 359-406.

Piper, A.M., 1944, A graphic procedure in the geochemical interpretation of water analyses: American Geophysical Union Transactions, v. 25, p. 914-923.

Plummer, L.N., Jones, B.F., and Truesdell, A.H., 1976, WATEQFA FORTRAN IV version of WATEQ, A computer program for calculating chemical equilibrium of natural waters: U.S. Geological Survey Water-Resources Investigations 76-13 (rev. 1978), 63 p.

Presser, T.S., and Barnes, Ivan, 1974, Special techniques for determining chemical properties of geothermal water: U.S. Geological Survey Water-Resources Investigations 22-74, $11 \mathrm{p}$.

Reed, M.J., ed., 1983, Assessment of low-temperature geothermal resources of the United States-1982: U.S. Geological Survey Circular $892,73 \mathrm{p}$.

Robertson, E.C., 1979, Thermal conductivities of rocks: U.S. Geological Survey Open-File Report 79-356, 31 p.

Sammel, E.A., 1979, Occurrence of low-temperature geothermal waters in the United States, in Muffler, L.J.P., ed., Assessment of geothermal resources of the United States-1978: U.S. Geological Survey Circular 790, p. 86-131.

Sass, J.H., Diment, W.H., Lachenbruch, A.H., Marshall, B.V., Munroe, R.J., Moses, T.H., Jr., and Urban, T.C., 1976, A new heat-flow 
contour map of the conterminous United States, 1976: U.S. Geological Survey Open-File Report 76-756, 24 p.

Senterfit, R.M., 1980, Principal facts for a gravity survey of the Ennis, Montana, geothermal area: U.S. Geological Survey Open-File Report 80-98, $8 \mathrm{p}$.

Smith, R.B., and Sbar, M.L., 1974, Contemporary tectonics and seismicity of the western United States, with emphasis on the Intermountain Seismic Belt: Geological Society of America Bulletin, v. 85 , no. 8 , p. $1205-1218$.

Smith, R.L., and Shaw, H.R., 1975, Igneous-related geothermal systems, in White, D.E., and Williams, D.L., eds., Assessment of geothermal resources of the United States-1975: U.S. Geological Survey Circular 726, p. 58-83.

Sonderegger, J.L., and Zaluski, Marek, 1983, Ennis geothermal system fracture porosity-An overthrust effect [abs., AAPG Rocky Mountain Section meeting, Billings, Montana, September 18-21, 1983]: American Association of Petroleum Geologists Bulletin, v. 67, no. 8, p. 1356.

Swanson, R.W., 1950, Geology of a part of the Virginia City and Eldridge quadrangles, Montana: U.S. Geological Survey Openfile report, $12 \mathrm{p}$.

Tilling, R.I., and Gottfried, David, 1969, Distribution of thorium, uranium, and potassium in igneous rocks of the Boulder batholith region, Montana, and its bearing on radiogenic heat production and heat flow: U.S. Geological Survey Professional Paper 614-E, p. E1-E29.

Truesdell, A.H., and Fournier, R.O., 1977, Procedure for estimating the temperature of a hot-water component in a mixed water by using a plot of dissolved silica versus enthalpy: U.S. Geological Survey Journal of Research, v. 5, no. 1, p. 49-52.

U.S. Environmental Protection Agency, 1977, National interim primary drinking water regulations: Washington, D.C., U.S. Government Printing Office, EPA-57019-76-003, 159 p.

1979, National secondary drinking water regulations: Federal Register, v. 44, no. 140, p. 42195-42202.

Vitaliano, C.J., and Cordua, W.S., 1979, Geologic map of the southern Tobacco Root Mountains, Madison County, Montana: Geological Society of America Map and Chart Series, MC-31, scale 1:62,500.

White, D.E., 1973, Characteristics of geothermal resources, in Kruger, Paul, and Otte, Carel, eds., Geothermal energy-Resources, production, and stimulation: Stanford University Press, p. 69-94.

White, D.E., Muffler, L.J.P., and Truesdell, A.H., 1971, Vapordominated hydrothermal systems compared with hot-water systems: Economic Geology, v. 66, no. 1, p. 75-97.

White, D.E., and Williams, D.L., eds., 1975, Assessment of geothermal resources of the United States-1975: U.S. Geological Survey Circular 726, 155 p.

Witkind, I.J., 1975, Preliminary map showing known and suspected active faults in western Montana: U.S. Geological Survey OpenFile Report 75-285, 36 p.

Zohdy, A.A.R., Eaton, G.P., and Mabey, D.R., 1974, Application of surface geophysics to ground-water investigations: U.S. Geological Survey Techniques of Water-Resources Investigations, Book 2, Chap. D1, 116 p. 


\section{TABLES}

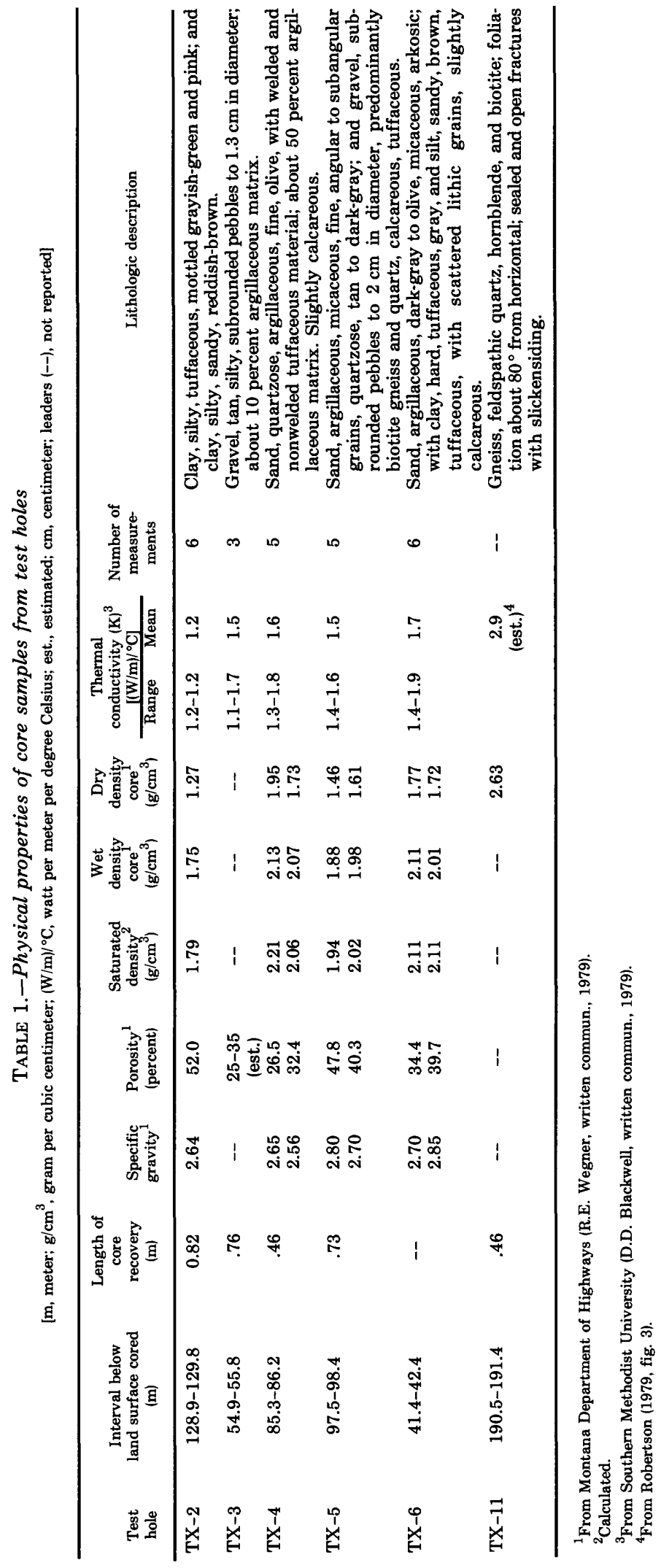


TABLE 2.-Water levels, subsurface temperatures, and $\left[\mathrm{m}\right.$, meter; ${ }^{\circ} \mathrm{C}$, degrees Celsius; ${ }^{\circ} \mathrm{C} / \mathrm{km}$, degrees Celsius per kilometer; mm, millimeter;

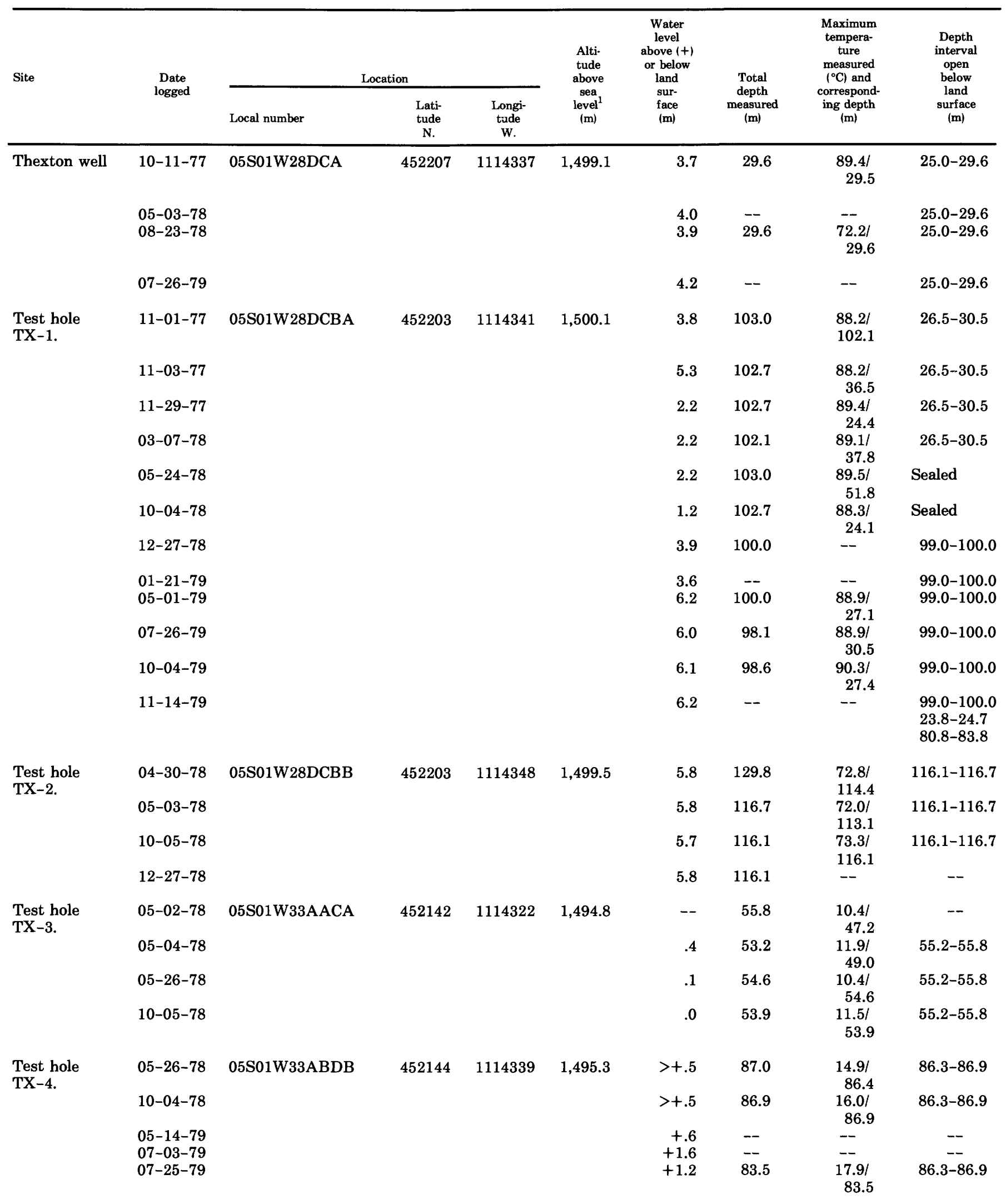




\begin{tabular}{|c|c|c|c|c|c|c|c|c|c|}
\hline & Subsur & $\begin{array}{l}\text { ace temp } \\
\text { belo }\end{array}$ & $\begin{array}{l}\text { erature } \\
\text { land st } \\
\left({ }^{\circ} \mathrm{C}\right)\end{array}$ & $\begin{array}{l}\text { t select } \\
\text { rface }\end{array}$ & depths & & $\begin{array}{l}\text { Temperature } \\
\text { gradient }\end{array}$ & $\begin{array}{c}\text { Interval } \\
\text { below } \\
\text { land } \\
\text { surface }\end{array}$ & Remarks \\
\hline $10 \mathrm{~m}$ & $30 \mathrm{~m}$ & $50 \mathrm{~m}$ & $70 \mathrm{~m}$ & $90 \mathrm{~m}$ & $110 \mathrm{~m}$ & $130 \mathrm{~m}$ & $\left({ }^{\circ} \mathrm{C} / \mathbf{k m}\right)$ & & \\
\hline 75.0 & -- & -- & -- & -- & -- & -- & $\begin{array}{r}1,195 \\
61\end{array}$ & $\begin{array}{l}11.0-18.3 \\
21.5-29.5\end{array}$ & $\begin{array}{l}\text { Perforated 152-mm casing, open end. } \\
\text { Logged after intermittent pumping. }\end{array}$ \\
\hline-- & -- & -- & -- & -- & -- & -- & -- & -- & -- \\
\hline 37.5 & -- & -- & -- & -- & -- & -- & 1,687 & $14.9-29.6$ & $\begin{array}{l}\text { Logged after non-use for about } 2 \text { months. Possible cold-water } \\
\text { leakage from pump tubing. }\end{array}$ \\
\hline-- & -- & -- & -- & -- & -- & -- & -- & -- & -- \\
\hline 59.4 & 82.9 & 85.2 & 85.5 & 86.3 & -- & -- & 40 & $24.4-102.1$ & $\begin{array}{l}\text { Steel casing sealed. Not grouted. Water level measured in adjacent } \\
\text { plastic pipe. }\end{array}$ \\
\hline 64.1 & 86.4 & 87.6 & 87.2 & 87.2 & -- & -- & -6 & $43.0-102.7$ & Do. \\
\hline 77.2 & 89.4 & 89.3 & 88.6 & 88.2 & -- & -- & -21 & $26.0-101.2$ & Do. \\
\hline 72.9 & 89.1 & 89.0 & 88.7 & 88.3 & -- & -- & -10 & 24.4-88.4 & Do. \\
\hline 74.9 & 88.8 & 89.4 & 88.5 & 88.1 & -- & -- & -17 & $24.4-103.0$ & Steel casing sealed. Grouted to depth of $30.5 \mathrm{~m}$. \\
\hline 75.5 & 88.3 & 88.3 & 88.3 & 87.2 & -- & -- & -16 & $24.1-102.7$ & Do. \\
\hline- & -- & -- & -- & -- & -- & -- & -- & -- & Charge detonated at depth of $100 \mathrm{~m}$ in steel pipe $12-10-78$. \\
\hline-- & - & -- & -- & -- & -- & -- & -- & -- & -- \\
\hline 77.2 & 88.9 & 88.9 & 88.3 & 88.3 & -- & -- & -12 & $27.1-100.0$ & Water level measured in steel pipe. \\
\hline 75.2 & 88.9 & 88.8 & 88.0 & 87.4 & -- & -- & -35 & $51.8-98.1$ & Do. \\
\hline 77.4 & 90.3 & 90.2 & 89.5 & 89.0 & -- & -- & -25 & $27.4-98.6$ & Do. \\
\hline-- & -- & -- & -- & -- & -- & -- & -- & -- & $\begin{array}{l}\text { Measurement before gun perforation. Mud level at depth of } 13.4 \\
\text { m after perforation. Hole destroyed. }\end{array}$ \\
\hline 18.2 & 45.2 & 58.8 & 64.3 & 66.0 & 70.4 & -- & $\begin{array}{l}102 \\
323\end{array}$ & $\begin{array}{l}61: 0-91.4 \\
91.4-114.3\end{array}$ & Screened sand point. \\
\hline 16.3 & 44.6 & 58.4 & 65.3 & 67.5 & 71.3 & -- & 141 & $61.0-112.8$ & Do. \\
\hline 16.5 & 45.2 & 60.3 & 67.2 & 69.1 & 72.2 & -- & 143 & $57.9-115.8$ & Do. \\
\hline-- & -- & -- & -- & -- & -- & -- & -- & -- & Hole destroyed during seismic survey 01-79. \\
\hline 7.8 & 9.4 & -- & - & -- & -- & -- & 72 & $6.1-47.2$ & -- \\
\hline 7.5 & 9.8 & 11.9 & -- & -- & -- & -- & 112 & $6.1-51.5$ & Screened sand point. \\
\hline 6.4 & 8.5 & 10.2 & -- & -- & -- & -- & 94 & $6.1-54.6$ & Do. \\
\hline 7.9 & 9.6 & 11.2 & -- & -- & -- & -- & 83 & $9.1-53.9$ & Hole destroyed during seismic survey 01-79. \\
\hline 6.2 & 9.5 & 12.0 & 13.7 & -- & -- & - & 100 & $12.2-86.9$ & Screened sand point. Flow $<0.01 \mathrm{~L} / \mathrm{s}$ at land surface. \\
\hline 7.8 & 10.6 & 12.7 & 13.8 & -- & -- & -- & 100 & $9.45-86.9$ & Do. \\
\hline-- & -- & -- & -- & -- & -- & -- & -- & -- & Casing extended above land surface. \\
\hline- & - & -- & - & -- & -- & -- & -- & - & Do. \\
\hline 9.1 & 12.4 & 14.8 & 16.6 & -- & -- & -- & 108 & $15.2-83.5$ & Do. \\
\hline
\end{tabular}


TABLE 2.-Water levels, subsurface temperatures, and

\begin{tabular}{|c|c|c|c|c|c|c|c|c|c|}
\hline \multirow[t]{2}{*}{ Site } & \multirow{2}{*}{$\begin{array}{c}\text { Date } \\
\text { logged }\end{array}$} & \multicolumn{3}{|c|}{ Location } & \multirow{2}{*}{$\begin{array}{c}\text { Alti- } \\
\text { tude } \\
\text { above } \\
\text { sea } \\
\text { level }^{1} \\
\text { (m) }\end{array}$} & \multirow{2}{*}{$\begin{array}{l}\text { Water } \\
\text { level } \\
\text { above }(+) \\
\text { or below } \\
\text { land } \\
\text { sur- } \\
\text { face } \\
\text { (m) }\end{array}$} & \multirow{2}{*}{$\begin{array}{c}\text { Total } \\
\text { depth } \\
\text { measured } \\
\text { (m) }\end{array}$} & \multirow{2}{*}{$\begin{array}{l}\text { Maximum } \\
\text { tempera- } \\
\text { ture } \\
\text { measured } \\
\left.{ }^{\circ} \mathrm{C}\right) \text { and } \\
\text { correspond- } \\
\text { ing depth } \\
(\mathrm{m})\end{array}$} & \multirow{2}{*}{$\begin{array}{c}\text { Depth } \\
\text { interval } \\
\text { open } \\
\text { below } \\
\text { land } \\
\text { surface } \\
\text { (m) }\end{array}$} \\
\hline & & Local number & $\begin{array}{c}\text { Lati- } \\
\text { tude } \\
\text { N. }\end{array}$ & $\begin{array}{c}\text { Longi- } \\
\text { tude } \\
\text { W. }\end{array}$ & & & & & \\
\hline \multirow[t]{9}{*}{$\begin{array}{l}\text { Test hole } \\
\text { TX-5. }\end{array}$} & $05-26-78$ & 05S01W28DDBC & 452201 & 1114329 & $1,491.8$ & +3.2 & 98.5 & $\begin{array}{c}60.4 / \\
98.1\end{array}$ & $97.2-97.8$ \\
\hline & $10-04-78$ & & & & & +3.6 & 97.5 & $\begin{array}{c}61.9 / \\
97.5\end{array}$ & $97.2-97.8$ \\
\hline & $05-14-79$ & & & & & +3.0 & -- & -- & -- \\
\hline & $07-03-79$ & & & & & +3.6 & - & -- & $97.2-97.8$ \\
\hline & $07-26-79$ & & & & & +3.8 & -- & $\begin{array}{c}61.2 / \\
97.0\end{array}$ & $97.2-97.8$ \\
\hline & $11-28-79$ & & & & & Flowing & 64.0 & $\begin{array}{c}59.7 / \\
64.0\end{array}$ & $\begin{array}{l}97.2-97.8 \\
40.5-42.7\end{array}$ \\
\hline & $12-05-79$ & & & & & .9 & 93.3 & $\begin{array}{r}61.4 / \\
93.3\end{array}$ & $\begin{array}{l}97.2-97.8 \\
40.5-42.7\end{array}$ \\
\hline & $12-27-79$ & & & & & 1.5 & - & -- & $\begin{array}{l}97.2-97.8 \\
40.5-42.7\end{array}$ \\
\hline & $03-25-80$ & & & & & 1.3 & 93.6 & $\begin{array}{c}61.9 / \\
93.6\end{array}$ & $\begin{array}{l}97.2-97.8 \\
40.5-42.7\end{array}$ \\
\hline \multirow[t]{5}{*}{$\begin{array}{l}\text { Test hole } \\
\text { TX-6. }\end{array}$} & $05-26-78$ & 05S01W28BCBD & 452225 & 1114417 & $1,496.1$ & +2.7 & 61.0 & $\begin{array}{r}17.9 / \\
60.4\end{array}$ & $60.3-60.9$ \\
\hline & $07-11-78$ & & & & & +3.4 & 60.4 & $\begin{array}{c}20.1 / \\
60.4\end{array}$ & $60.3-60.9$ \\
\hline & $10-06-78$ & & & & & +3.5 & 60.4 & $\begin{array}{c}19.1 / \\
60.4\end{array}$ & $60.3-60.9$ \\
\hline & $05-14-79$ & & & & & +2.3 & -- & -- & $60.3-60.9$ \\
\hline & $\begin{array}{l}07-03-79 \\
07-26-79\end{array}$ & & & & & $\begin{array}{l}+2.3 \\
+2.2\end{array}$ & $\overline{60.0}$ & $\begin{array}{r}-- \\
18.8 / \\
60.0\end{array}$ & $\begin{array}{l}60.3-60.9 \\
60.3-60.9\end{array}$ \\
\hline $\begin{array}{l}\text { Test hole } \\
\text { TX-7. }\end{array}$ & $11-01-78$ & 05S01W33BBAA & 452149 & 1114412 & $1,502.2$ & 3.6 & 15.2 & $\begin{array}{r}12.0 / \\
6.4\end{array}$ & $>15.2$ \\
\hline \multirow{12}{*}{$\begin{array}{l}\text { Test hole } \\
\text { TX-8. }\end{array}$} & $12-01-78$ & 05S01W21DCDB & 452249 & 1114339 & $1,489.1$ & 5.3 & 15.2 & -- & $12.2-15.24$ \\
\hline & $12-27-78$ & & & & & 5.4 & 13.1 & $\begin{array}{r}11.6 / \\
12.2\end{array}$ & $12.2-15.24$ \\
\hline & $04-09-79$ & & & & & .6 & 100.6 & $\begin{array}{c}30.4 / \\
91.4\end{array}$ & Sealed \\
\hline & $04-16-79$ & & & & & .6 & 90.8 & $\begin{array}{c}30.0 / \\
90.8\end{array}$ & Sealed \\
\hline & $04-30-79$ & & & & & .5 & 90.8 & $\begin{array}{r}29.8 / \\
90.8\end{array}$ & Sealed \\
\hline & $09-27-79$ & & & & & .8 & 90.3 & $\begin{array}{r}28.7 / \\
90.3\end{array}$ & Sealed \\
\hline & $11-17-79$ & & & & & 3.0 & 71.0 & -- & $\begin{array}{l}61.0-64.0 \\
76.2-79.2\end{array}$ \\
\hline & $11-29-79$ & & & & & 2.3 & 71.3 & $\begin{array}{r}23.0 / \\
71.3\end{array}$ & $\begin{array}{l}61.0-64.0 \\
76.2-79.2\end{array}$ \\
\hline & $12-04-79$ & & & & & 2.3 & -- & -- & $\begin{array}{l}61.0-64.0 \\
76.2-79.2\end{array}$ \\
\hline & $12-06-79$ & & & & & 2.0 & -- & -- & $\begin{array}{l}61.0-64.0 \\
76.2-79.2\end{array}$ \\
\hline & $12-27-79$ & & & & & 2.1 & -- & -- & $\begin{array}{l}61.0-64.0 \\
76.2-79.2\end{array}$ \\
\hline & $03-25-80$ & & & & & 2.4 & -- & -- & $\begin{array}{l}61.0-64.0 \\
76.2-79.2\end{array}$ \\
\hline \multirow[t]{2}{*}{$\begin{array}{l}\text { Test hole } \\
\text { TX-9. }\end{array}$} & $04-30-79$ & 05S01W33BBAA02 & 452151 & 1114400 & $1,501.9$ & .3 & 124.0 & $\begin{array}{l}42.0 / \\
121.3\end{array}$ & Sealed \\
\hline & 07-29-79 & & & & & -- & 120.0 & $\begin{array}{l}41.3 / \\
120.0\end{array}$ & Sealed \\
\hline
\end{tabular}


geothermal gradients from wells, test holes, and shotholes-Continued

\begin{tabular}{|c|c|c|c|c|c|c|c|c|c|}
\hline \multirow[b]{2}{*}{$10 \mathrm{~m}$} & \multicolumn{6}{|c|}{$\begin{array}{l}\text { Subsurface temperature at selected depths } \\
\text { below land surface } \\
\left({ }^{\circ} \mathrm{C}\right)\end{array}$} & \multirow{2}{*}{$\begin{array}{l}\text { Temperature } \\
\text { gradient } \\
\left({ }^{\circ} \mathrm{C} / \mathrm{km}\right)\end{array}$} & \multirow{2}{*}{$\begin{array}{c}\text { Interval } \\
\text { below } \\
\text { land } \\
\text { surface } \\
(\mathrm{m})\end{array}$} & \multirow[t]{2}{*}{ Remarks } \\
\hline & $30 \mathrm{~m}$ & $50 \mathrm{~m}$ & $70 \mathrm{~m}$ & $90 \mathrm{~m}$ & $110 \mathrm{~m}$ & $130 \mathrm{~m}$ & & & \\
\hline 21.0 & 44.2 & 47.0 & 48.5 & 49.7 & -- & -- & 82 & $30.8-91.4$ & Abundant gas bubbles. \\
\hline-- & -- & -- & -- & -- & -- & -- & -- & -- & -- \\
\hline 25.1 & 53.9 & 58.3 & -- & -- & -- & -- & 120 & $36.6-64.0$ & $\begin{array}{l}\text { Gun perforated } 11-17-79 \text {. Partly plugged with debris. Flowing } \\
<0.01 \mathrm{~L} / \mathrm{s} \text { after removal of ice-filled extension. }\end{array}$ \\
\hline 24.8 & 52.6 & 57.5 & 59.6 & 60.8 & -- & -- & 93 & $39.6-93.3$ & -- \\
\hline-- & -- & -- & -- & -- & -- & -- & -- & -- & -- \\
\hline 12.3 & 16.9 & 19.0 & -- & -- & -- & -- & $\begin{array}{l}248 \\
108\end{array}$ & $\begin{array}{r}3.0-24.4 \\
30.5-61.0\end{array}$ & Do. \\
\hline 11.5 & 15.8 & 18.3 & -- & -- & -- & -- & 150 & $3.4-60.2$ & Do. \\
\hline- & -- & -- & -- & -- & -- & -- & -- & -- & Do. \\
\hline-- & -- & -- & -- & -- & -- & -- & -- & -- & Do. \\
\hline-- & -- & -- & -- & -- & -- & -- & -- & -- & Bottom-hole reading only. \\
\hline 11.5 & -- & - & -- & - & -- & -- & -- & $4.6-15.2$ & $\begin{array}{l}\text { Measurements in 152-mm open-end casing. Pumped } 1.9 \mathrm{~L} / \mathrm{s} \text { on com- } \\
\text { pletion. Hole destroyed 01-79. }\end{array}$ \\
\hline 9.8 & 13.0 & 16.6 & 21.8 & 28.6 & -- & -- & 226 & $9.1-90.3$ & Do. \\
\hline-- & -- & -- & - & -- & -- & -- & -- & -- & $\begin{array}{l}\text { Gun perforated } 11-16-79 \text { to } 11-17-79 . \text { Sediment entered casing } \\
\text { through perforations. }\end{array}$ \\
\hline 11.2 & 14.0 & 17.7 & 22.5 & -- & -- & -- & $\begin{array}{l}139 \\
236\end{array}$ & $\begin{array}{r}3.0-39.6 \\
39.6-71.3\end{array}$ & Do. \\
\hline-- & -- & -- & -- & -- & -- & -- & - & -- & Do. \\
\hline-- & -- & -- & - & -- & -- & -- & -- & -- & Do. \\
\hline-- & -- & -- & -- & -- & - & -- & -- & -- & Do. \\
\hline-- & -- & -- & -- & -- & -- & -- & -- & -- & Do. \\
\hline 11.8 & 17.3 & 22.1 & 28.0 & 34.8 & 39.4 & -- & 278 & $12.2-121.3$ & Top of metamorphic bedrock at depth of $106.1 \mathrm{~m}$. \\
\hline-- & -- & -- & -- & -- & -- & -- & -- & -- & Bottom-hole reading only. \\
\hline
\end{tabular}


TABLE 2.-Water levels, subsurface temperatures, and

\begin{tabular}{|c|c|c|c|c|c|c|c|c|c|}
\hline \multirow[t]{2}{*}{ Site } & \multirow{2}{*}{$\begin{array}{c}\text { Date } \\
\text { logged }\end{array}$} & & & & \multirow{2}{*}{$\begin{array}{c}\text { Alti- } \\
\text { tude } \\
\text { above } \\
\text { sea } \\
\text { level }^{1} \\
\text { (m) }\end{array}$} & \multirow{2}{*}{$\begin{array}{l}\text { Water } \\
\text { level } \\
\text { above }(+) \\
\text { or below } \\
\text { land } \\
\text { sur- } \\
\text { face } \\
\text { (m) }\end{array}$} & \multirow{2}{*}{$\begin{array}{c}\text { Total } \\
\text { depth } \\
\text { measured } \\
\text { (m) }\end{array}$} & \multirow{2}{*}{$\begin{array}{c}\text { Maximum } \\
\text { tempera- } \\
\text { ture } \\
\text { measured } \\
\left({ }^{\circ} \mathrm{C}\right) \text { and } \\
\text { correspond- } \\
\text { ing depth } \\
(\mathrm{m})\end{array}$} & \multirow{2}{*}{$\begin{array}{c}\text { Depth } \\
\text { interval } \\
\text { open } \\
\text { below } \\
\text { land } \\
\text { surface } \\
\text { (m) }\end{array}$} \\
\hline & & Local number & $\begin{array}{c}\text { Lati- } \\
\text { tude } \\
\text { N. }\end{array}$ & $\begin{array}{c}\text { Longi- } \\
\text { tude } \\
\text { W. }\end{array}$ & & & & & \\
\hline & $09-19-79$ & & & & & 1.4 & 120.1 & $\begin{array}{l}42.0 / \\
120.1\end{array}$ & Sealed \\
\hline & $11-17-79$ & & & & & 6.7 & -- & -- & $\begin{array}{r}97.5-100.6 \\
112.8-115.8\end{array}$ \\
\hline & $11-29-79$ & & & & & 7.3 & 118.9 & $\begin{array}{l}41.6 / \\
118.9\end{array}$ & $\begin{array}{r}97.5-100.6 \\
112.8-115.8\end{array}$ \\
\hline & $12-05-79$ & & & & & 7.9 & -- & -- & $\begin{array}{r}97.5-100.6 \\
112.8-115.8\end{array}$ \\
\hline & $12-27-79$ & & & & & 7.4 & -- & - & $\begin{array}{r}97.5-100.6 \\
112.8-115.8\end{array}$ \\
\hline & $03-25-80$ & & & & & 8.8 & -- & -- & $\begin{array}{r}97.5-100.6 \\
112.8-115.8\end{array}$ \\
\hline \multirow[t]{5}{*}{$\begin{array}{l}{ }^{2} \text { Test hole } \\
\text { TX-10. }\end{array}$} & $10-02-79$ & 05S01W23CCBD & 452252 & 1114149 & $\begin{array}{l}1,480 \\
\text { (est.) }\end{array}$ & +5.8 & 33.5 & -- & $26.5-33.5$ \\
\hline & $10-10-79$ & & & & & -- & 266.9 & $\begin{array}{l}28.7 ! \\
266.9\end{array}$ & Sealed \\
\hline & $11-07-79$ & & & & & -- & 258.5 & $\begin{array}{l}26.9 / \\
258.5\end{array}$ & Sealed \\
\hline & $11-29-79$ & & & & & +3.0 & 222.5 & $\begin{array}{l}23.81 \\
222.5\end{array}$ & $225.6-228.6$ \\
\hline & $03-05-80$ & & & & & +2.7 & -- & -- & $225.6-228.6$ \\
\hline \multirow[t]{8}{*}{$\begin{array}{l}{ }^{3} \text { Test hole } \\
\text { TX-11. }\end{array}$} & $09-26-79$ & 05S01W28DABC02 & 452214 & 1114328 & $1,489.3$ & -- & 190.7 & $\begin{array}{l}88.3 / \\
182.9\end{array}$ & -- \\
\hline & $09-28-79$ & & & & & -- & 181.9 & $\begin{array}{l}93.2 / \\
181.9\end{array}$ & Sealed \\
\hline & $10-06-79$ & & & & & +11.0 & 185.3 & $\begin{array}{l}94.1 / \\
185.3\end{array}$ & Sealed \\
\hline & $11-06-79$ & & & & & +11.0 & 182.9 & $\begin{array}{l}94.0 / \\
182.9\end{array}$ & Sealed \\
\hline & $\begin{array}{l}11-15-79 \\
11-16-79\end{array}$ & & & & & $\begin{array}{l}+11.4 \\
+12.2\end{array}$ & $\begin{array}{l}-- \\
--\end{array}$ & -- & $\begin{array}{l}170.7-176.8 \\
157.0-176.8\end{array}$ \\
\hline & $11-29-79$ & & & & & +12.3 & 158.5 & $\begin{array}{c}93.9 / \\
134.1 \\
\text { and } \\
158.5\end{array}$ & $157.0-176.8$ \\
\hline & $12-27-79$ & & & & & +11.6 & -- & -- & $157.0-176.8$ \\
\hline & $03-24-80$ & & & & & +11.0 & -- & -- & $157.0-176.8$ \\
\hline \multirow[t]{2}{*}{$\begin{array}{l}\text { Shothole } \\
\text { SH-1. }\end{array}$} & $11-02-78$ & 05S01W28DABC01 & 452214 & 1114328 & $1,489.3$ & +.2 & 15.4 & $\begin{array}{c}62.1 / \\
15.4\end{array}$ & $15.4-15.5$ \\
\hline & $03-28-79$ & & & & & +.1 & 6.6 & -- & -- \\
\hline \multirow[t]{4}{*}{$\begin{array}{l}\text { Shothole } \\
\text { SH-3. }\end{array}$} & $11-01-78$ & 05S01W33BBCC & 452140 & 1114426 & $1,503.3$ & 3.4 & 15.3 & $\begin{array}{r}11.7 / \\
8.8\end{array}$ & $13.3-15.2$ \\
\hline & $\begin{array}{l}12-27-78 \\
03-26-79\end{array}$ & & & & & $\begin{array}{l}5.5 \\
6.2\end{array}$ & $\begin{array}{l}15.3 \\
15.3\end{array}$ & $\begin{array}{l}-- \\
--\end{array}$ & $\begin{array}{l}13.3-15.2 \\
13.3-15.2\end{array}$ \\
\hline & $04-09-79$ & & & & & 3.2 & 26.5 & $\begin{array}{r}10.9 / \\
24.4\end{array}$ & Sealed \\
\hline & $09-27-79$ & & & & & 3.4 & 25.6 & $\begin{array}{r}10.8 / \\
26.1\end{array}$ & Sealed \\
\hline \multirow[t]{4}{*}{$\begin{array}{l}\text { Shothole } \\
\text { SH-4. }\end{array}$} & $11-01-78$ & 05S01W28CABD & 452212 & 1114402 & $1,497.8$ & 3.8 & 14.3 & $\begin{array}{c}11.9 / \\
14.3\end{array}$ & $13.7-14.3$ \\
\hline & $\begin{array}{l}12-27-78 \\
04-30-79\end{array}$ & & & & & $\begin{array}{l}4.1 \\
+.9\end{array}$ & $\begin{array}{l}14.3 \\
43.3\end{array}$ & $\begin{array}{c}-- \\
24.0 / \\
43.3\end{array}$ & $\begin{array}{l}13.7-14.3 \\
\text { Sealed }\end{array}$ \\
\hline & $07-26-79$ & & & & & -- & -- & $\begin{array}{r}23.4 / \\
43.0\end{array}$ & Sealed \\
\hline & $09-27-79$ & & & & & +.1 & 42.7 & $\begin{array}{r}22.81 \\
42.7\end{array}$ & Sealed \\
\hline
\end{tabular}


geothermal gradients from wells, test holes, and shotholes-Continued

\begin{tabular}{|c|c|c|c|c|c|c|c|c|c|}
\hline \multirow[b]{2}{*}{$10 \mathrm{~m}$} & \multicolumn{6}{|c|}{$\begin{array}{l}\text { Subsurface temperature at selected depths } \\
\text { below land surface } \\
\left({ }^{\circ} \mathrm{C}\right)\end{array}$} & \multirow{2}{*}{$\begin{array}{l}\text { Temperature } \\
\text { gradient } \\
\left({ }^{\circ} \mathrm{C} / \mathbf{k m}\right)\end{array}$} & \multirow{2}{*}{$\begin{array}{l}\text { Interval } \\
\text { below } \\
\text { land } \\
\text { surface } \\
\text { (m) }\end{array}$} & \multirow[t]{2}{*}{ Remarks } \\
\hline & $30 \mathrm{~m}$ & $50 \mathrm{~m}$ & $70 \mathrm{~m}$ & $90 \mathrm{~m}$ & $110 \mathrm{~m}$ & $130 \mathrm{~m}$ & & & \\
\hline 10.8 & 16.9 & 21.8 & 27.9 & 35.0 & 39.9 & -- & 289 & $6.1-120.1$ & -- \\
\hline-- & -- & -- & -- & -- & -- & -- & -- & -- & Gun perforated $11-16-79$ to $11-17-79$ \\
\hline 10.7 & 16.5 & 21.4 & 27.6 & 34.6 & 39.4 & -- & 293 & $15.2-118.9$ & -- \\
\hline-- & -- & -- & -- & -- & -- & -- & -- & -- & -- \\
\hline-- & -- & -- & -- & -- & -- & -- & - & -- & -- \\
\hline-- & -- & -- & -- & -- & -- & -- & -- & -- & Plugged at $5.5 \mathrm{~m}$. \\
\hline-- & -- & -- & -- & -- & -- & -- & - & -- & $\begin{array}{l}\text { Well flowed } 3.8 \mathrm{~L} / \mathrm{s} \text { while drilling at } 33.5 \mathrm{~m} \text {. Leakage }<0.0002 \mathrm{~L} / \mathrm{s} \\
\text { after grouting. }\end{array}$ \\
\hline 10.9 & 14.2 & 13.3 & 13.9 & 15.7 & 16.2 & 17.5 & 63 & $57.9-225.6$ & -- \\
\hline 8.5 & 10.2 & 11.0 & 11.8 & 12.8 & 14.0 & 15.5 & $\begin{array}{l}52 \\
88\end{array}$ & $\begin{array}{r}27.4-137.2 \\
137.2-258.5\end{array}$ & Leakage $<0.0002 \mathrm{~L} / \mathrm{s}$ after grouting. \\
\hline 9.6 & 11.4 & 12.2 & 13.0 & 14.0 & 15.1 & 16.6 & $\begin{array}{l}49 \\
76\end{array}$ & $\begin{array}{r}15.2-118.9 \\
121.9-222.5\end{array}$ & Gun perforated 11-16-79. \\
\hline-- & -- & -- & -- & - & -- & -- & -- & -- & Flowing $<0.007 \mathrm{~L} / \mathrm{s}$. \\
\hline 47.4 & 71.1 & 77.7 & 81.0 & 80.6 & 81.6 & 83.1 & 66 & $61.0-187.4$ & $\begin{array}{l}\text { In drilling fluid. Top of metamorphic bedrock at depth of } \\
150.9-160.9 \mathrm{~m} \text {. }\end{array}$ \\
\hline 52.4 & 75.1 & 80.9 & 84.6 & 86.4 & 87.2 & 89.8 & 79 & $67.1-181.9$ & After grouting. Slight flow. \\
\hline 51.2 & 78.5 & 83.9 & 86.1 & 86.8 & 87.8 & 89.1 & 73 & $39.6-185.3$ & Pipe sealed but flowing $<0.002 \mathrm{~L} / \mathrm{s}$. \\
\hline 52.9 & 79.5 & 85.2 & 86.7 & 87.2 & 88.1 & 89.7 & $\begin{array}{r}52 \\
132 \\
46\end{array}$ & $\begin{array}{r}42.7-131.1 \\
131.1-152.4 \\
152.4-182.9\end{array}$ & 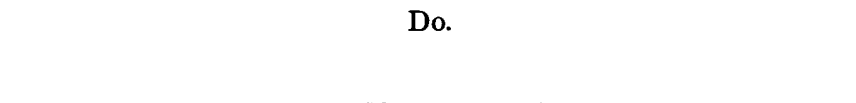 \\
\hline-- & - & -- & -- & -- & -- & -- & -- & -- & Gun perforated 11-15-79. Flow $0.033 \mathrm{~L} / \mathrm{s}$. \\
\hline-- & -- & -- & -- & -- & -- & -- & - & -- & $\begin{array}{l}\text { Gun perforated 11-16-79. Flow increased to } 0.17 \mathrm{~L} / \mathrm{s} \text {. Gun- } \\
\text { perforation frame lodged at depth of } 158.5 \mathrm{~m} \text {. }\end{array}$ \\
\hline 91.6 & 92.0 & 92.4 & 92.8 & 93.3 & 93.6 & 93.8 & 16 & $6.1-158.5$ & -- \\
\hline-- & -- & -- & -- & -- & -- & -- & -- & -- & $\begin{array}{l}\text { Fishing tool lodged in hole } 12-05-79 \text { precluded additional logging. } \\
\text { Flowing } 0.5 \mathrm{~L} / \mathrm{s} \text { at surface. }\end{array}$ \\
\hline-- & -- & -- & -- & -- & -- & -- & -- & -- & Flowing $0.17 \mathrm{~L} / \mathrm{s}$ at surface. \\
\hline 45.4 & -- & -- & -- & -- & -- & -- & -- & -- & $\begin{array}{l}\text { Flowing } 0.25 \mathrm{~L} / \mathrm{s} \text { in } 152 \mathrm{~mm} \text { in diameter conductor pipe, open at } \\
\text { base. }\end{array}$ \\
\hline-- & -- & -- & -- & -- & -- & -- & -- & -- & After use as seismic shothole. \\
\hline 11.0 & -- & -- & -- & -- & -- & -- & -89 & $3.0-15.3$ & In 152-mm conductor pipe before deepening. \\
\hline-- & -- & -- & -- & -- & -- & -- & -- & -- & Do. \\
\hline-- & -- & -- & -- & -- & -- & -- & -- & -- & Do. \\
\hline 9.9 & -- & -- & -- & -- & -- & -- & 35 & $12.2-26.1$ & Not grouted. Top of metamorphic bedrock at depth of $24.4 \mathrm{~m}$. \\
\hline 9.1 & -- & -- & -- & -- & -- & -- & 49 & $9.1-25.6$ & Grouted near surface only. Drilling mud in annulus. \\
\hline 10.8 & -- & -- & -- & -- & -- & -- & 725 & $3.0-5.9$ & In 152-mm conductor pipe before deepening. \\
\hline-- & -- & -- & -- & -- & -- & -- & -- & -- & Do. \\
\hline 10.1 & 18.4 & -- & -- & -- & -- & -- & 411 & $9.8-43.3$ & Grouted near surface only. Drilling mud in annulus. \\
\hline-- & -- & -- & - & -- & -- & -- & -- & -- & Bottom-hole reading only. \\
\hline 9.3 & 17.5 & -- & -- & -- & -- & -- & 414 & $9.1-42.7$ & -- \\
\hline
\end{tabular}


TABLE 2.-Water levels, subsurface temperatures, and

\begin{tabular}{|c|c|c|c|c|c|c|c|c|c|}
\hline \multirow[t]{2}{*}{ Site } & \multirow{2}{*}{$\begin{array}{c}\text { Date } \\
\text { logged }\end{array}$} & \multicolumn{3}{|c|}{ Location } & \multirow{2}{*}{$\begin{array}{c}\text { Alti- } \\
\text { tude } \\
\text { above } \\
\text { sea } \\
\text { level } \\
\text { (m) }\end{array}$} & \multirow{2}{*}{$\begin{array}{l}\text { Water } \\
\text { level } \\
\text { above (+) } \\
\text { or below } \\
\text { land } \\
\text { sur- } \\
\text { face } \\
\text { (m) }\end{array}$} & \multirow{2}{*}{$\begin{array}{l}\text { Total } \\
\text { depth } \\
\text { measured } \\
\text { (m) }\end{array}$} & \multirow{2}{*}{$\begin{array}{l}\text { Maximum } \\
\text { tempera- } \\
\text { ture } \\
\text { measured } \\
\left({ }^{\circ} \mathrm{C}\right) \text { and } \\
\text { correspond- } \\
\text { ing depth } \\
\text { (m) }\end{array}$} & \multirow{2}{*}{$\begin{array}{c}\text { Depth } \\
\text { interval } \\
\text { open } \\
\text { below } \\
\text { land } \\
\text { surface } \\
\text { (m) }\end{array}$} \\
\hline & & Local number & $\begin{array}{l}\text { Lati- } \\
\text { tude } \\
\mathrm{N} .\end{array}$ & $\begin{array}{l}\text { Longi- } \\
\text { tude } \\
\text { W. }\end{array}$ & & & & & \\
\hline \multirow[t]{2}{*}{$\begin{array}{l}\text { Shothole } \\
\text { SH-5. }\end{array}$} & $12-27-78$ & 05S01W27BCCB & 452221 & 1114311 & $1,487.7$ & .5 & 14.3 & $\begin{array}{c}18.9 / \\
14.3\end{array}$ & $14.2-14.3$ \\
\hline & $01-29-79$ & & & & & .7 & 14.3 & -- & -- \\
\hline $\begin{array}{l}\text { Cyprus } \\
\text { Industrial } \\
\text { Minerals } \\
\text { Company } \\
\text { No. } 1 \text { well. }\end{array}$ & $03-15-79$ & 05S01W28DBCB01 & 452208 & 1114349 & $1,498.3$ & 7.0 & 25.3 & $\begin{array}{c}44.21 \\
24.7\end{array}$ & -- \\
\hline $\begin{array}{l}\text { Cyprus } \\
\text { Industrial } \\
\text { Minerals } \\
\text { Company } \\
\text { No. 2 well. }\end{array}$ & $03-15-79$ & 05S01W28DBCB02 & 452209 & 1114349 & $1,498.1$ & 5.7 & 12.5 & $\begin{array}{c}18.5 / \\
12.5\end{array}$ & -- \\
\hline Griffin well & $03-16-79$ & 05S01W28ACBC & 452226 & 1114346 & $1,494.2$ & 5.6 & 66.1 & $\begin{array}{c}45.2 / \\
66.1\end{array}$ & $\begin{array}{l}51.8-53.6 \\
54.0-65.8\end{array}$ \\
\hline Jeffers well & $04-12-79$ & 06S01E03BDB & 452043 & 1113524 & $\begin{array}{l}1,696 \\
\text { (est.) }\end{array}$ & - & 99.1 & $\begin{array}{l}9.4 / \\
95.7\end{array}$ & -- \\
\hline Matzig well & $07-12-78$ & 06S01W06BBAB & 452104 & 1114542 & $1,543.7$ & 34.9 & 76.5 & $\begin{array}{c}11.21 \\
70.1\end{array}$ & -- \\
\hline \multirow[t]{2}{*}{$\begin{array}{l}\text { McClellan } \\
\text { No. } 2 \text { well. }\end{array}$} & $05-01-79$ & 06S01W06ABCB & 452047 & 1114610 & $\begin{array}{l}1,658 \\
\text { (est.) }\end{array}$ & 47.0 & -- & -- & -- \\
\hline & $\begin{array}{l}07-02-79 \\
08-14-79\end{array}$ & & & & & $\begin{array}{l}16.3 \\
11.6\end{array}$ & $\overline{82.4}$ & $\begin{array}{c}-- \\
11.6 / \\
79.2\end{array}$ & -- \\
\hline \multirow[t]{3}{*}{ Pray well } & $09-27-77$ & 05S01W28ACDD & 452220 & 1114334 & $1,495.9$ & 6.1 & 41.4 & $\begin{array}{c}47.21 \\
40.2\end{array}$ & $42.0-42.7$ \\
\hline & $10-12-77$ & & & & & 6.1 & 39.6 & $\begin{array}{c}46.1 / \\
38.1\end{array}$ & $42.0-42.7$ \\
\hline & $12-28-78$ & & & & & 6.6 & -- & -- & $42.0-42.7$ \\
\hline \multirow[t]{2}{*}{ Toth well } & $03-22-78$ & 05S01W28ACBA & 452227 & 1114344 & $1,494.4$ & 7.2 & 63.1 & $\begin{array}{r}42.9 / \\
61.6\end{array}$ & $60.0-61.6$ \\
\hline & $07-11-78$ & & & & & 7.4 & 64.0 & $\begin{array}{r}42.1 / \\
64.0\end{array}$ & -- \\
\hline \multirow[t]{8}{*}{ Yenny well } & $08-19-77$ & 05S01W28DCCA & 452158 & 1114340 & 1,501 & 5.4 & 37.2 & $\begin{array}{r}36.1 / \\
36.6\end{array}$ & $29.3-38.1$ \\
\hline & $10-12-77$ & & & & & 5.3 & 36.3 & $\begin{array}{r}35.6 / \\
33.5\end{array}$ & $29.3-38.1$ \\
\hline & $11-29-77$ & & & & & 6.3 & -- & -- & $29.3-38.1$ \\
\hline & $03-07-78$ & & & & & 6.8 & 37.8 & $\begin{array}{c}34.3 / \\
30.8\end{array}$ & $29.3-38.1$ \\
\hline & $05-21-78$ & & & & & 6.4 & -- & -- & $29.3-38.1$ \\
\hline & $12-28-78$ & & & & & 6.3 & -- & -- & 29.3-38.1 \\
\hline & 05-01-79 & & & & & 6.6 & -- & -- & $29.3-38.1$ \\
\hline & $07-03-79$ & & & & & 6.6 & -- & -- & $29.3-38.1$ \\
\hline
\end{tabular}

\footnotetext{
${ }^{1}$ All altitudes were determined from the bench mark $(1,492 \mathrm{~m})$ shown in figure 5 .

${ }^{2}$ Additional subsurface temperatures $\left({ }^{\circ} \mathrm{C}\right)$ at selected depths $(\mathrm{m})$ in test hole TX-10 on date indicated:

$10-10-79 \frac{150 \mathrm{~m}}{18.8} \frac{170 \mathrm{~m}}{20.0} \frac{190 \mathrm{~m}}{21.3} \frac{210 \mathrm{~m}}{22.7} \frac{230 \mathrm{~m}}{24.7} \frac{250 \mathrm{~m}}{26.3} \quad \frac{270 \mathrm{~m}}{--}$

11-07-79 $\frac{150 \mathrm{~m}}{17.0} \frac{170 \mathrm{~m}}{18.4} \frac{190 \mathrm{~m}}{20.0} \frac{210 \mathrm{~m}}{21.6} \frac{230 \mathrm{~m}}{23.6} \frac{250 \mathrm{~m}}{25.8} \frac{270 \mathrm{~m}}{--}$

11-29-79 $\frac{150 \mathrm{~m}}{17.9} \frac{170 \mathrm{~m}}{19.5} \frac{190 \mathrm{~m}}{21.0} \frac{210 \mathrm{~m}}{22.6} \frac{230 \mathrm{~m}}{--} \frac{250 \mathrm{~m}}{--} \frac{270 \mathrm{~m}}{--}$
} 


\begin{tabular}{|c|c|c|c|c|c|c|c|c|c|}
\hline & Subsurf & $\begin{array}{l}\text { ace temp } \\
\text { belo }\end{array}$ & $\begin{array}{l}\text { erature } \\
\text { land } \mathrm{s} \\
\left({ }^{\circ} \mathrm{C}\right)\end{array}$ & $\begin{array}{l}\text { It selecte } \\
\text { Irface }\end{array}$ & depths & & $\begin{array}{l}\text { Temperature } \\
\text { gradient }\end{array}$ & $\begin{array}{l}\text { Interval } \\
\text { below } \\
\text { land } \\
\text { surface }\end{array}$ & Remarks \\
\hline $10 \mathrm{~m}$ & $30 \mathrm{~m}$ & $50 \mathrm{~m}$ & $70 \mathrm{~m}$ & $90 \mathrm{~m}$ & $110 \mathrm{~m}$ & $130 \mathrm{~m}$ & $\left({ }^{\circ} \mathrm{C} / \mathbf{k m}\right)$ & & \\
\hline 16.2 & -- & -- & -- & -- & -- & -- & 467 & $3.0-14.3$ & 152-mm open-end casing; hole destroyed. \\
\hline-- & -- & -- & -- & -- & -- & -- & -- & -- & -- \\
\hline 17.4 & -- & -- & -- & -- & -- & -- & 1,777 & $6.4-24.4$ & -- \\
\hline 16.9 & - & -- & -- & -- & -- & -- & 726 & $6.1-12.5$ & For domestic use. \\
\hline 12.6 & 23.0 & 41.3 & -- & - & -- & -- & 28 & $54.9-66.1$ & 152-mm open-end casing. Airlift $1.77 \mathrm{~L} / \mathrm{s}$ on completion. \\
\hline 6.4 & 7.9 & 8.7 & 8.9 & 9.0 & -- & -- & 32 & $9.1-93.3$ & East edge Madison Valley. Dry. \\
\hline 15.4 & 11.3 & 10.5 & 11.2 & -- & -- & -- & 27 & 46.0-76.5 & Fractured gneiss-southwest of hot spring. \\
\hline- & -- & -- & -- & - & -- & -- & -- & -- & -- \\
\hline-- & - & -- & -- & -- & -- & -- & -- & -- & -- \\
\hline 9.9 & 10.5 & 11.2 & 11.4 & -- & -- & -- & 21 & $12.2-82.4$ & $\begin{array}{l}\text { Fractured gneiss-southwest of hot spring. Well filling slowly after } \\
\text { completion. }\end{array}$ \\
\hline 18.3 & 42.8 & -- & -- & -- & -- & -- & $\begin{array}{r}1,175 \\
196\end{array}$ & $\begin{array}{r}9.1-33.5 \\
33.5-41.4\end{array}$ & $\begin{array}{l}\text { 152-mm open-end casing. Yield } 1.9 \mathrm{~L} / \mathrm{s} \text { on } \\
\text { completion. }\end{array}$ \\
\hline 17.7 & 40.3 & -- & -- & -- & -- & -- & $\begin{array}{r}1,336 \\
32\end{array}$ & $\begin{array}{l}15.2-33.6 \\
38.1-41.3\end{array}$ & -- \\
\hline-- & -- & -- & -- & -- & -- & -- & -- & -- & -- \\
\hline 12.3 & 26.1 & 40.0 & -- & -- & -- & -- & $\begin{array}{r}665 \\
44\end{array}$ & $\begin{array}{r}3.4-58.2 \\
58.2-63.1\end{array}$ & 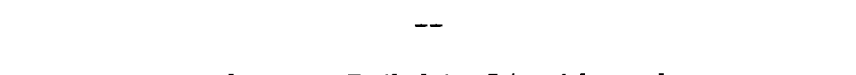 \\
\hline 20.0 & 24.2 & 37.4 & -- & -- & -- & -- & 683 & $15.5-58.2$ & 152-mm open-end casing. Bailed $2.5 \mathrm{~L} / \mathrm{s}$ with sand. \\
\hline 23.6 & 35.8 & -- & -- & -- & -- & -- & 141 & $15.2-37.0$ & 152-mm open-end casing. Pumped $2.5 \mathrm{~L} / \mathrm{s}$. \\
\hline 31.6 & 35.5 & -- & -- & -- & -- & -- & 63 & $15.2-33.5$ & -- \\
\hline-- & -- & -- & -- & -- & -- & -- & -- & -- & -- \\
\hline 33.3 & 34.3 & -- & -- & -- & -- & -- & 47 & $9.5-33.5$ & -- \\
\hline-- & -- & -- & -- & -- & -- & -- & -- & -- & -- \\
\hline-- & -- & -- & -- & -- & -- & -- & -- & -- & -- \\
\hline -- & -- & -- & -- & -- & -- & -- & -- & -- & -- \\
\hline-- & -- & -- & -- & -- & -- & -- & -- & -- & -- \\
\hline
\end{tabular}

\footnotetext{
${ }^{3}$ Additional subsurface temperatures $\left({ }^{\circ} \mathrm{C}\right)$ at selected depths $(\mathrm{m})$ in test hole TX-11 on date indicated: 09-26-79 $\frac{150 \mathrm{~m}}{85.3} \frac{170 \mathrm{~m}}{87.2} \frac{190 \mathrm{~m}}{--} \frac{210 \mathrm{~m}}{--}$

$09-28-79 \frac{150 \mathrm{~m}}{91.1} \frac{170 \mathrm{~m}}{92.8} \frac{190 \mathrm{~m}}{--}$

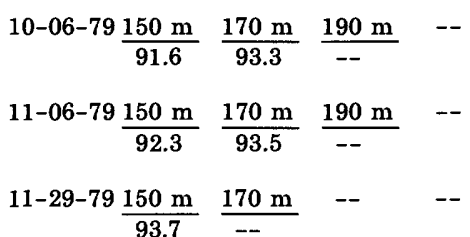


TABLE 3.-Selected chemical analyses and minimum equilibrium temperatures [Analyses by U.S. Geological Survey; m, meters; ${ }^{\circ} \mathrm{C}$, degrees Celsius; $\mathrm{mg} / \mathrm{L}$, milligrams per liter; $\mu \mathrm{g} / \mathrm{L}$, micrograms per liter;

\begin{tabular}{|c|c|c|c|c|c|c|c|c|c|c|c|c|}
\hline \multirow[b]{2}{*}{ Sample } & \multirow[b]{2}{*}{ Site } & \multirow[b]{2}{*}{$\begin{array}{c}\text { Date } \\
\text { sampled }\end{array}$} & \multirow{2}{*}{$\begin{array}{l}\text { Depth to } \\
\text { top of } \\
\text { sampling } \\
\text { interval } \\
\text { below } \\
\text { land } \\
\text { surface } \\
\text { (m) }\end{array}$} & \multirow[b]{2}{*}{$\begin{array}{l}\text { Meas- } \\
\text { ured } \\
\text { tem- } \\
\text { pera- } \\
\text { ture }{ }^{1} \\
\left({ }^{\circ} \mathrm{C}\right)\end{array}$} & \multirow{2}{*}{$\begin{array}{c}\text { On- } \\
\text { site } \\
\text { spe- } \\
\text { cific } \\
\text { con- } \\
\text { duct- } \\
\text { ance } \\
(\mu \mathrm{S} / \mathrm{cm})\end{array}$} & \multirow[b]{2}{*}{$\begin{array}{c}\text { On-site } \\
\text { pH } \\
\text { (units) }\end{array}$} & \multicolumn{6}{|c|}{ Concentration $(\mathrm{mg} / \mathrm{L})$} \\
\hline & & & & & & & $\begin{array}{c}\text { Cal- } \\
\text { cium, } \\
\text { dis- } \\
\text { solved } \\
\text { (as Ca) }\end{array}$ & $\begin{array}{c}\text { Magne- } \\
\text { sium, } \\
\text { dis- } \\
\text { solved } \\
\text { (as } \mathrm{Mg} \text { ) }\end{array}$ & $\begin{array}{c}\text { Sodium, } \\
\text { dis- } \\
\text { solved } \\
\text { (as } \mathrm{Na} \text { ) }\end{array}$ & $\begin{array}{l}\text { Potas- } \\
\text { sium, } \\
\text { dis- } \\
\text { solved } \\
\text { (as K) }\end{array}$ & $\begin{array}{c}\text { On-site } \\
\text { alka- } \\
\text { linity } \\
\text { (as } \\
\mathrm{CaCO}_{3} \text { ) }\end{array}$ & $\begin{array}{c}\text { Sul- } \\
\text { fate, } \\
\text { dis- } \\
\text { solved } \\
\text { (as } \mathrm{SO}_{4} \text { ) }\end{array}$ \\
\hline \multicolumn{13}{|c|}{ Field A, cool, local ground water from shallow source [dissolved solids $<400 \mathrm{mg} / \mathrm{L}, \mathrm{Ca}^{2+}-\mathrm{HCO}_{3}{ }^{-}$] } \\
\hline 1 & SH-3 & $11-01-78$ & 15.2 & 10.4 & 341 & 7.8 & 32 & 11 & 21 & 8.2 & 130 & 29 \\
\hline 2 & Northway & $06-08-78$ & 12.8 & 12.2 & 453 & 7.6 & 50 & 18 & 18 & 4.5 & 170 & 30 \\
\hline 3 & Nelson & $09-07-77$ & 13.7 & 16.0 & 410 & -- & 47 & 14 & 22 & 5.1 & 160 & 33 \\
\hline 4 & Sportsman's Lodge & $06-08-78$ & 24.4 & 12.8 & 450 & 7.7 & 54 & 19 & 17 & 4.8 & 180 & 32 \\
\hline 5 & Thexton cold spring & $04-01-76$ & -- & 7.8 & 458 & 7.7 & 50 & 20 & 25 & 5.4 & 209 & 34 \\
\hline 6 & $\mathrm{TX}-7$ & $11-01-78$ & 15.2 & 10.6 & 493 & 7.4 & 58 & 17 & 25 & 7.4 & 200 & 35 \\
\hline 7 & Ennis Ranger Station ${ }^{3}$ & $03-28-79$ & 41.1 & 13.0 & 507 & 7.4 & 55 & 17 & 23 & 8.9 & 190 & 43 \\
\hline 8 & $\mathrm{SH}-4$ & $11-02-78$ & 14.0 & 11.9 & 569 & 7.5 & 66 & 20 & 26 & 6.6 & 190 & 88 \\
\hline \multicolumn{13}{|c|}{ Field B, warmed local ground water and dilute thermal watar [disaolved solids $<400 \mathrm{mg} / \mathrm{L}, \mathrm{Na}^{+}-\mathrm{HCO}_{3}{ }^{-}$] } \\
\hline 9 & TX-4 & $06-08-78$ & 86.9 & 14.8 & 348 & 8.2 & 3.7 & .9 & 75 & 5.1 & 150 & 18 \\
\hline 10 & TX-9 & $12-05-79$ & 94.5 & 40.3 & 376 & 9.4 & 5.1 & .4 & 110 & 7.3 & 200 & 33 \\
\hline 11 & TX-8 & $12-05-79$ & 64.0 & 23.0 & 570 & 8.9 & 9.6 & .8 & 110 & 4.7 & 180 & 59 \\
\hline 12 & TX -5 & $06-08-78$ & 97.0 & 60.4 & 630 & 8.3 & 3.3 & .2 & 130 & 4.3 & 210 & 43 \\
\hline $12 \mathrm{a}$ & TX-5 & $12-04-79$ & 40.5 & 36.0 & 600 & 9.7 & 7.6 & .9 & 120 & 3.8 & 200 & 52 \\
\hline 13 & Cyprus No. 2 & $04-20-79$ & 11.6 & 18.5 & 611 & 8.9 & 5.6 & 1.3 & 140 & 7.1 & 210 & 68 \\
\hline \multicolumn{13}{|c|}{ Field $\mathrm{C}$, thermal water from nonflowing source [dissolved solids $\left.>700 \mathrm{mg} / \mathrm{L}, \mathrm{Na}^{+}-\left(\mathrm{S}^{2} \mathrm{O}_{4}{ }^{-}, \mathrm{Cl}^{-}\right)\right]$} \\
\hline 14 & Griffin & $03-16-79$ & 54.9 & 45.2 & 1,215 & 8.2 & 9.1 & .9 & 240 & 7.8 & 280 & 160 \\
\hline 15 & TX-2 & $10-06-78$ & 116.7 & 72.8 & 1,550 & 7.5 & 5.0 & .1 & 270 & 8.3 & 210 & 210 \\
\hline 16 & Cyprus No. 1 & $07-25-79$ & 24.7 & 44.2 & 1,470 & 7.6 & 4.4 & .5 & 290 & 13 & 290 & 210 \\
\hline 17 & Toth & $05-12-78$ & 63.1 & 42.1 & 1,470 & 7.8 & 9.3 & 2.0 & 310 & 9.3 & 340 & 170 \\
\hline 18 & Pray & $06-08-78$ & 41.1 & 46.1 & 1,530 & 7.5 & 5.0 & 1.0 & 330 & 12 & 350 & 190 \\
\hline 19 & TX-1 & $06-10-79$ & 98.8 & 88.3 & 1,520 & 8.6 & 3.5 & .3 & 340 & 15 & 320 & 220 \\
\hline \multicolumn{13}{|c|}{ Field $\mathrm{C}$, thermal water from flowing source [dissolved solids $\left.>950 \mathrm{mg} / \mathrm{L}, \mathrm{Na}^{+}-\left(\mathrm{SO}_{4}^{2}{ }^{-}, \mathrm{Cl}^{-}\right)\right]$} \\
\hline 20 & SH-1 & $11-02-78$ & 16.2 & 62.1 & 1,530 & 7.1 & 5.8 & .6 & 330 & 18 & 350 & 210 \\
\hline 21 & Ennis Hot Spring & $03-24-80$ & -- & 75.5 & 1,540 & 8.4 & 5.5 & .1 & 320 & 15 & 350 & 210 \\
\hline 22 & Ennis Hot Spring & $04-01-76$ & -- & 83.2 & 1,510 & 7.7 & 5.8 & .6 & 340 & 17 & 363 & 220 \\
\hline 23 & Thexton ${ }^{4}$ & $04-01-76$ & 29.3 & 72.2 & 1,540 & 8.7 & 5.8 & .9 & 330 & 17 & 358 & 250 \\
\hline 24 & TX-11 & $11-16-79$ & 157.0 & 94.0 & 1,480 & 8.9 & 5.9 & .2 & 330 & 24 & 370 & 210 \\
\hline 25 & TX-11 & $12-27-79$ & 157.0 & 93.9 & 1,610 & 8.9 & 4.8 & .0 & 340 & 16 & 330 & 270 \\
\hline \multicolumn{13}{|c|}{ Outside field boundaries } \\
\hline 26 & Yenny & $05-11-78$ & 37.8 & 34.3 & 527 & 7.4 & 28 & 5.6 & 75 & 5.8 & 160 & 52 \\
\hline 27 & $\mathrm{TX}-6$ & $06-08-78$ & 60.4 & 20.1 & 812 & 7.2 & 2.1 & .4 & 180 & 9.4 & 220 & 91 \\
\hline 28 & TX-10 (deep) ${ }^{3}$ & $03-26-80$ & 225.6 & 23.0 & 300 & 9.7 & 5.5 & 2.8 & 49 & 15 & 68 & 57 \\
\hline 29 & TX-10 (shallow) $^{3}$ & $10-02-79$ & 33.5 & 10.8 & 389 & 8.9 & 44 & 16 & 10 & 2.0 & 130 & 63 \\
\hline
\end{tabular}


of water from wells, test holes, shotholes, and springs

$\mu \mathrm{S} / \mathrm{cm}$, microsiemens per centimeter at $25{ }^{\circ} \mathrm{Celsius;}>$, greater than; $<$, less than]

\begin{tabular}{|c|c|c|c|c|c|c|c|c|c|c|}
\hline \multicolumn{4}{|c|}{ Concentration $(\mathrm{mg} / \mathrm{L})$-Continued } & \multirow{2}{*}{\multicolumn{4}{|c|}{ Concentration $(\mu \mathrm{g} / \mathrm{L})$}} & \multirow{3}{*}{\multicolumn{3}{|c|}{$\begin{array}{l}\text { Estimated equilibrium tempera- } \\
\text { ture determined by indicated } \\
\text { type of geothermometer }\left({ }^{\circ} \mathrm{C}\right)\end{array}$}} \\
\hline \multirow{3}{*}{$\begin{array}{l}\text { Chlo- } \\
\text { ride, } \\
\text { dis- } \\
\text { solved } \\
\text { (as Cl) }\end{array}$} & \multirow{3}{*}{$\begin{array}{l}\text { Fluo- } \\
\text { ride, } \\
\text { dis- } \\
\text { solved } \\
\text { (as F) }\end{array}$} & \multirow[b]{3}{*}{ 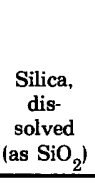 } & \multirow{3}{*}{$\begin{array}{l}\text { Solids, } \\
\text { sum of } \\
\text { constit- } \\
\text { uents, } \\
\text { dis- } \\
\text { solved }\end{array}$} & & & & & & & \\
\hline & & & & \multirow[b]{2}{*}{$\begin{array}{c}\text { Boron, } \\
\text { dis- } \\
\text { solved } \\
\text { (as B) }\end{array}$} & \multirow[b]{2}{*}{$\begin{array}{c}\text { Iron, } \\
\text { dis- } \\
\text { solved } \\
\text { (as Fe) }\end{array}$} & \multirow[b]{2}{*}{$\begin{array}{l}\text { Lithium, } \\
\text { dis- } \\
\text { solved } \\
\text { (as Li) }\end{array}$} & \multirow{2}{*}{$\begin{array}{c}\text { Manga- } \\
\text { nese, } \\
\text { dis- } \\
\text { solved } \\
\text { (as } \mathrm{Mn} \text { ) }\end{array}$} & & & \\
\hline & & & & & & & & $\begin{array}{c}\mathrm{Na}-\mathrm{K}-\mathrm{Ca} \\
\text { (cation) }^{2}\end{array}$ & $\begin{array}{l}\text { Quartz } \\
\text { con- } \\
\text { ductive }\end{array}$ & $\begin{array}{l}\text { Chal- } \\
\text { cedony }\end{array}$ \\
\hline \multicolumn{11}{|c|}{ Field A-Continued } \\
\hline 15 & 0.5 & 30 & 226 & 80 & 20 & 20 & 70 & 50 & 79 & 48 \\
\hline 18 & .5 & 31 & 278 & 70 & 120 & 30 & 0 & 39 & 81 & 50 \\
\hline 21 & .4 & 41 & 284 & 50 & 1,400 & 30 & 30 & 45 & 93 & 62 \\
\hline 21 & .3 & 34 & 295 & 50 & 160 & 20 & 5 & 39 & 85 & 54 \\
\hline 19 & .8 & 31 & 314 & 110 & 0 & 40 & 0 & 47 & 81 & 51 \\
\hline 16 & .3 & 39 & 320 & 90 & 20 & 20 & 20 & 52 & 91 & 60 \\
\hline 29 & .8 & 48 & 345 & 120 & 1,300 & 50 & 30 & 58 & 100 & 70 \\
\hline 21 & .4 & 28 & 371 & 70 & 110 & 30 & 210 & 47 & 77 & 45 \\
\hline \multicolumn{11}{|c|}{ Field B-Continued } \\
\hline 10 & .9 & 42 & 246 & 50 & 280 & 50 & 5 & 89 & 94 & 63 \\
\hline 18 & 2.0 & 43 & 340 & 130 & 200 & 60 & 1 & 146 & 95 & 64 \\
\hline 8.5 & 2.7 & 34 & 348 & 100 & 90 & 30 & 1 & 91 & 85 & 54 \\
\hline 20 & 3.4 & 44 & 374 & 200 & 330 & 70 & 0 & 117 & 96 & 66 \\
\hline 24 & 3.4 & 52 & 385 & 220 & 110 & 60 & 4 & 90 & 104 & 74 \\
\hline 24 & 2.1 & 23 & 398 & 90 & 730 & 30 & 10 & 89 & 69 & 37 \\
\hline \multicolumn{11}{|c|}{ Field C, nonflowing-Continued } \\
\hline 68 & 11 & 46 & 712 & 380 & 110 & 170 & 20 & 121 & 98 & 68 \\
\hline 110 & 10 & 46 & 786 & 580 & 10 & 150 & 0 & 140 & 98 & 68 \\
\hline 73 & 6.8 & 72 & 845 & 390 & 30 & 240 & 20 & 145 & 120 & 91 \\
\hline 100 & 7.7 & 47 & 859 & 380 & 290 & 200 & 10 & 87 & 99 & 69 \\
\hline 110 & 9.1 & 75 & 945 & 540 & 220 & 250 & 5 & 113 & 122 & 93 \\
\hline 120 & 9.5 & 45 & 945 & 710 & 560 & 210 & 7 & 157 & 97 & 68 \\
\hline \multicolumn{11}{|c|}{ Field C, flowing-Continued } \\
\hline 110 & 9.5 & 90 & 985 & 640 & 160 & 260 & 30 & 154 & 131 & 104 \\
\hline 120 & 10 & 100 & 992 & 620 & 10 & 280 & 20 & 159 & 137 & 110 \\
\hline 120 & 11 & 96 & 1,030 & 610 & 20 & 260 & 10 & 151 & 135 & 108 \\
\hline 110 & 11 & 98 & 1,040 & 610 & -- & -- & -- & 136 & 136 & 109 \\
\hline 110 & 20 & 120 & 1,050 & 740 & 160 & 240 & 6 & 183 & 148 & 120 \\
\hline 120 & 9.8 & 160 & 1,120 & 610 & 200 & 200 & 30 & 166 & 165 & 142 \\
\hline \multicolumn{11}{|c|}{ Outside field boundaries - Continued } \\
\hline 32 & 1.8 & 43 & 342 & 120 & 70 & 60 & 5 & 70 & 95 & 65 \\
\hline 54 & 2.6 & 43 & 516 & 170 & 230 & 100 & 5 & 138 & 95 & 66 \\
\hline 7.2 & .5 & .3 & 180 & 770 & 40 & 30 & 9 & 79 & -- & -- \\
\hline 6.7 & .2 & 19 & 242 & 30 & 40 & 10 & 2 & 17 & -- & 29 \\
\hline
\end{tabular}







\section{SELECTED SERIES OF U.S. GEOLOGICAL SURVEY PUBLICATIONS}

\section{Perlodicals}

Earthquakes \& Volcanoes (issued bimonthly). Preliminary Determination of Epicenters (issued monthly).

\section{Technical Books and Reports}

Professional Papers are mainly comprehensive scientific reports of wide and lasting interest and importance to professional scientists and engineers. Included are reports on the results of resource studies and of topographic, hydrologic, and geologic investigations. They also include collections of related papers addressing different aspects of a single scientific topic.

Bulletins contain significant data and interpretations that are of lasting scientific interest but are generally more limited in scope or geographic coverage than Professional Papers. They include the results of resource studies and of geologic and topographic investigations; as well as collections of short papers related to a specific topic.

Water-Supply Papers are comprehensive reports that present significant interpretive results of hydrologic investigations of wide interest to professional geologists, hydrologists, and engineers. The series covers investigations in all phases of hydrology, including hydrogeology, availability of water, quality of water, and use of water.

Circulars present administrative information or important scientific information of wide popular interest in a format designed for distribution at no cost to the public. Information is usually of short-term interest.

Water-Resources Investigations Reports are papers of an interpretive nature made available to the public outside the formal USGS publications series. Copies are reproduced on request unlike formal USGS publications, and they are also available for public inspection at depositories indicated in USGS catalogs.

Open-File Reports include unpublished manuscript reports, maps, and other material that are made available for public consultation at depositories. They are a nonpermanent form of publication that may be cited in other publications as sources of information.

\section{Maps}

Geologic Quadrangle Maps are multicolor geologic maps on topographic bases in 7 1/2- or 15-minute quadrangle formats (scales mainly $1: 24,000$ or $1: 62,500$ ) showing bedrock, surficial, or engineering geology. Maps generally include brief texts; some maps include structure and columnar sections only.

Geophysical Investigations Maps are on topographic or planimetric bases at various scales; they show results of surveys using geophysical techniques, such as gravity, magnetic, seismic, or radioactivity, which reflect subsurface structures that are of economic or geologic significance. Many maps include correlations with the geology.

Miscellaneous Investigations Series Maps are on planimetric or topographic bases of regular and irregular areas at various scales; they present a wide variety of format and subject matter. The series also includes 7 1/2-minute quadrangle photogeologic maps on planimetric bases which show geology as interpreted from aerial photographs. Series also includes maps of Mars and the Moon.
Coal Investigations Maps are geologic maps on topographic or planimetric bases at various scales showing bedrock or surficial geology, stratigraphy, and structural relations in certain coal-resource areas.

Oll and Gas Investigations Charts show stratigraphic information for certain oil and gas fields and other areas having petroleum potential.

Miscellaneous Field Studies Maps are multicolor or black-andwhite maps on topographic or planimetric bases on quadrangle or irregular areas at various scales. Pre-1971 maps show bedrock geology in relation to specific mining or mineral-deposit problems; post-1971 maps are primarily black-and-white maps on various subjects such as environmental studies or wilderness mineral investigations.

Hydrologic Investigations Atlases are multicolored or black-andwhite maps on topographic or planimetric bases presenting a wide range of geohydrologic data of both regular and irregular areas; principal scale is $1: 24,000$ and regional studies are at $1: 250,000$ scale or smaller.

\section{Catalogs}

Permanent catalogs, as well as some others, giving comprehensive listings of U.S. Geological Survey publications are available under the conditions indicated below from the U.S. Geological Survey, Books and Open-File Reports Section, Federal Center, Box 25425, Denver, CO 80225. (See latest Price and Availability List.)

"Publications of the Geological Survey, 1879-1961" may be purchased by mail and over the counter in paperback book form and as a set of microfiche.

"Publications of the Geological Survey, 1962-1970" may be purchased by mail and over the counter in paperback book form and as a set of microfiche.

"Publications of the U.S. Geological Survey, 1971-1981" may be purchased by mail and over the counter in paperback book form (two volumes, publications listing and index) and as a set of microfiche.

Supplements for 1982, 1983, 1984, 1985, 1986, and for subsequent years since the last permanent catalog may be purchased by mail and over the counter in paperback book form.

State catalogs, "List of U.S. Geological Survey Geologic and Water-Supply Reports and Maps For (State)," may be purchased by mail and over the counter in paperback booklet form only

"Price and Avallability List of U.S. Geological Survey Publications," issued annually, is available free of charge in paperback booklet form only.

Selected copies of a monthly catalog "New Publications of the U.S. Geological Survey" available free of charge by mail or may be obtained over the counter in paperback booklet form only. Those wishing a free subscription to the monthly catalog "New Publications of the U.S. Geological Survey" should write to the U.S. Geological Survey, 582 National Center, Reston, VA 22092.

Note.--Prices of Government publications listed in older catalogs, announcements, and publications may be incorrect. Therefore, the prices charged may differ from the prices in catalogs, announcements, and publications. 